INTERNATIONAL MONETARY FUND

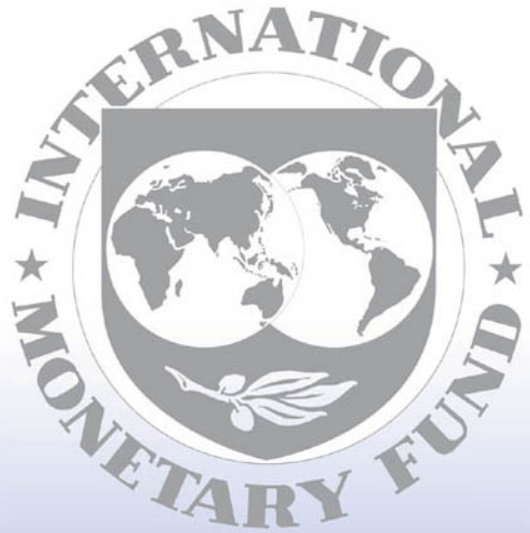

Staff

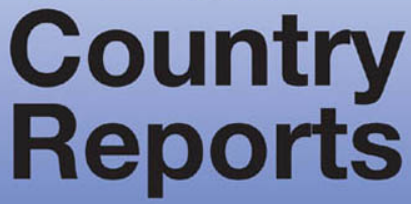




\section{Kingdom of Swaziland: Selected Issues and Statistical Appendix}

This Selected Issues paper and Statistical Appendix for the Kingdom of Swaziland was prepared by a staff team of the International Monetary Fund as background documentation for the periodic consultation with the member country. It is based on the information available at the time it was completed on January 22, 2008. The views expressed in this document are those of the staff team and do not necessarily reflect the views of the government of the Kingdom of Swaziland or the Executive Board of the IMF.

The policy of publication of staff reports and other documents by the IMF allows for the deletion of market-sensitive information.

To assist the IMF in evaluating the publication policy, reader comments are invited and may be sent by e-mail to publicationpolicy@imf.org.

Copies of this report are available to the public from

International Monetary Fund • Publication Services

700 19th Street, N.W. • Washington, D.C. 20431

Telephone: (202) 6237430 • Telefax: (202) 6237201

E-mail: publications@imf.org • Internet: http://www.imf.org

Price: $\$ 18.00$ a copy

\section{International Monetary Fund Washington, D.C.}


This page intentionally left blank 


\section{INTERNATIONAL MONETARY FUND \\ KINGDOM OF SWAZILAND \\ Selected Issues and Statistical Appendix}

Prepared by a staff team consisting of Wipada Soonthornsima (Head), Thomson Fontaine, Hamid Davoodi, and Alfredo Torrez (all AFR)

Approved by the African Department

January 22, 2008

Basic Data

Contents

I. Swaziland: Fiscal Policy and Sustainability.....

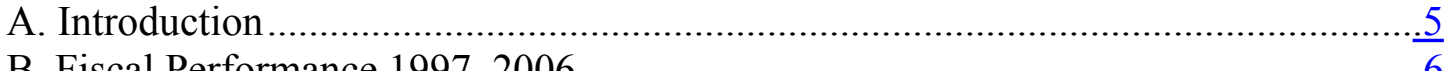

C. Medium-Term Outlook for Fiscal Policy and Growth..................................... $\frac{10}{14}$

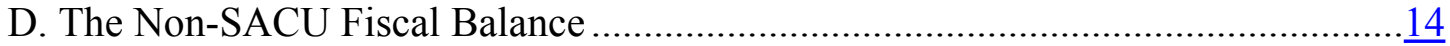



F. Fiscal Management and Fiscal Credibility ................................................ $\frac{18}{20}$

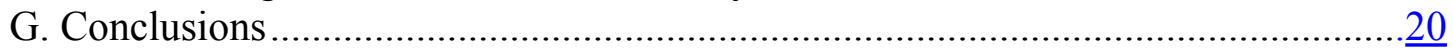

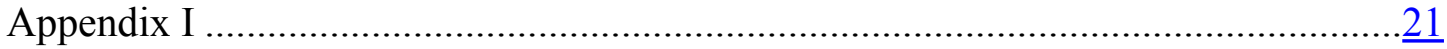

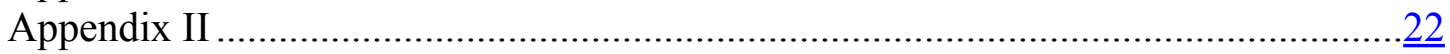

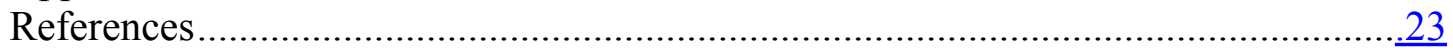

II. Swaziland's Financial Sector Development and Future Strategies.................................24

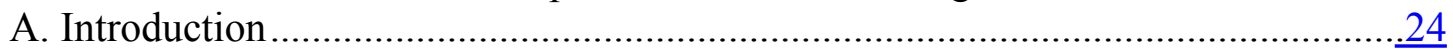

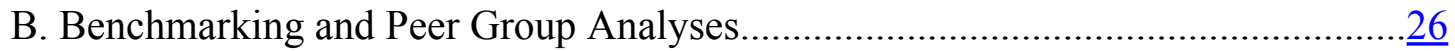

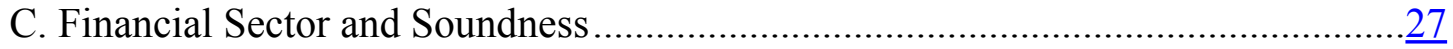

D. Financial Sector Efficiency and Profitability................................................. $\frac{38}{38}$

E. Key Constraints to a Deeper and Healthier Financial System .............................

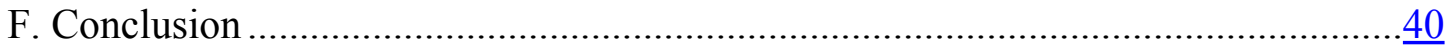

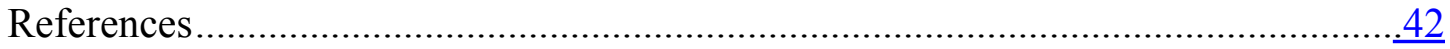

III. Responding to the Challenges in the Global Trading Regimes for Swaziland's Textiles

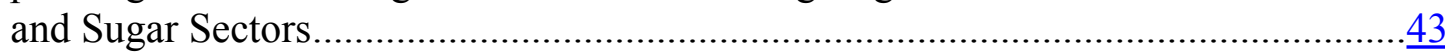

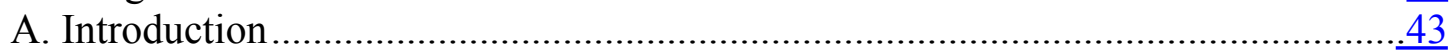

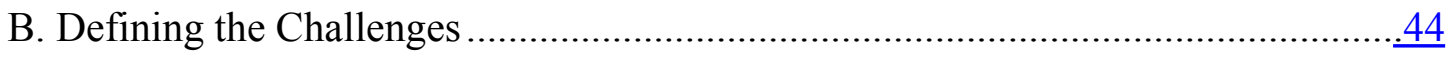

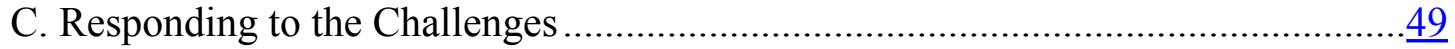

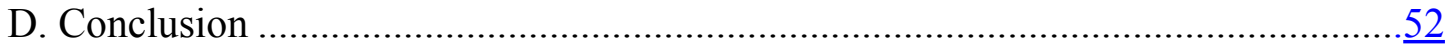

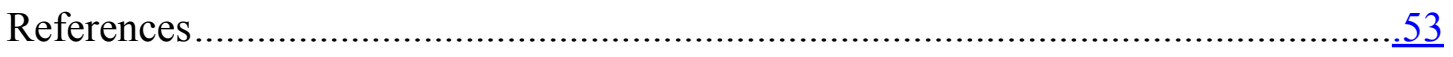


Tables

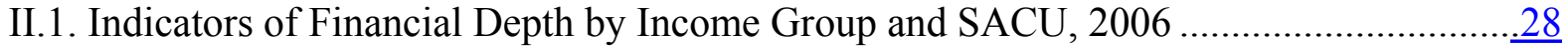

II.2. Swaziland's Banks: Ownership Structure and Size .................................................. $\frac{31}{32}$

II.3. Banking System Prudential Indicators ....................................................................

II.4. Banking System Efficiency Profitability.............................................................

Figures

I.1. SACU Countries: Revenue and Expenditure Indicators, 2004/05 …............................ $\underline{8}$

II.1. Banking Sector Depth and Economic Growth .......................................................25

II.2. Indicators of Banking System Depth: Swaziland and Various Peer Groups ..................29

II.3. Indicators of Banking System Depth: Swaziland and Other SACU Countries................ $\underline{30}$

II.4. Ratio of Nonperforming Loans to Total Loans in SACU Countries in 2006 .................32



II.6. Lending by Banks and SCCOs ....................................................................... $\frac{35}{37}$

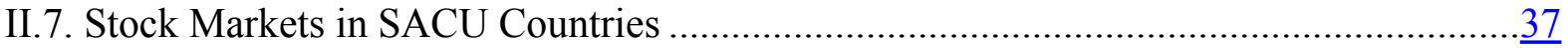

Statistical Tables

1. Gross Domestic Product by Sector of Origin at 2000 Constant Prices, 2001-06...............54

2. Gross Domestic Product by Sector of Origin at Current Prices, 2001-06.........................55

3. Gross Domestic Product by Expenditure Category at Current Prices, 2001-06 ................ $\underline{.56}$

4. Population and Labor Force Estimates, 2001-06 .....................................................

5. Developments in Crop Production, 2001/02-2006/07 …............................................58

6. Developments in Sugar Production, Processing, and Consumption, 2001/02-2006/07...... $\frac{59}{60}$

7. Mineral Production and Exports, 2001-06 ............................................................60

8. Electrical Power Generation and Demand, 2001-05 ................................................

9. Retail Price Indices of Urban Families, 2002-06 ...................................................... $\frac{62}{63}$

10. Minimum Wages for General Workers in Selected Industries, 2001-06 ........................63

11. Paid Employment in the Private and Public Sectors by Industry, 2001-05 ....................64

12. Summary of Central Government Operations, 2002/03-2006/07 ................................65

13. Central Government Revenue and Grants, 2002/03-2006/07 ......................................66

14. Functional Classification of Central Government Expenditure and Net Lending, ........... $\underline{67}$

15. Economic Classification of Government Current Expenditure, 2002/03-2006/07 ........... $\underline{68}$

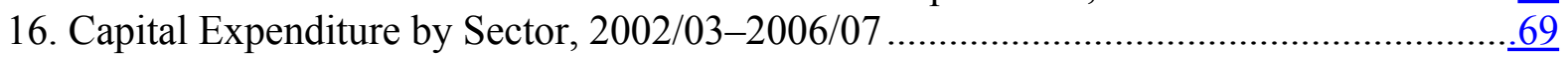

17. Government Transfer Payments, 2002/03-2006/01 ....................................................

18. Swaziland: Flow of Funds From the Government to Public Enterprises 2002/03-

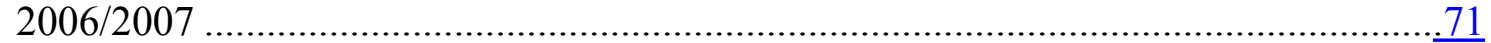

19. Outstanding Domestic Government Debt by Type of Instrument, 2002-November 2007...

20. Monetary Survey, 2002-07 .$\underline{72}$

21. Assets and Liabilities of the Central Bank of Swaziland, 2002-07 ................................74

22. Assets and Liabilities of Commercial Banks, 2002-07 .............................................. $\frac{75}{76}$

23. Commercial Banks' Deposits by Sector, 2002-07 ................................................. $\frac{76}{77}$

24. Commercial Banks' Liquidity Position, 2002-07 ....................................................... $\frac{77}{79}$

26. Interest Rates in Swaziland and South Africa, Dec. 2002-07 .....................................

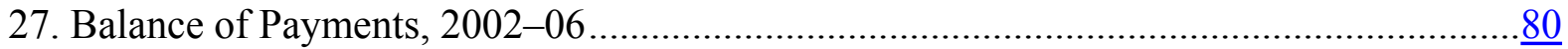

28. Balance of Payments, 2002-06 ............................................................................. 
29. Merchandise Exports, 2000-04 $\underline{82}$

30. Sugar Exports by Volume, Value, and Unit Price, 2001-05 ………………………..... $\frac{83}{83}$

31. Other Principal Exports by Volume, Value, and Unit Price, 2000-04 ……………….....

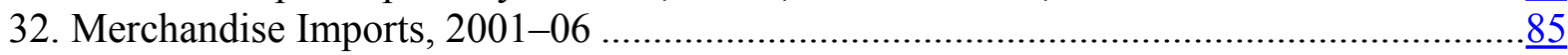

33: Services and Income Account, 2001-05 ................................................................

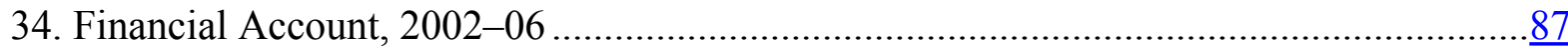

35. Public Sector External Debt, 2002/03-2006/071 ………….........................................88

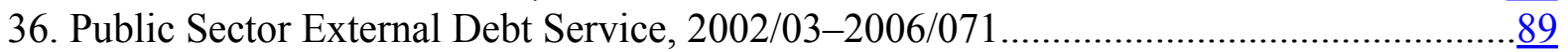

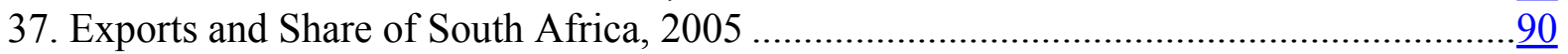

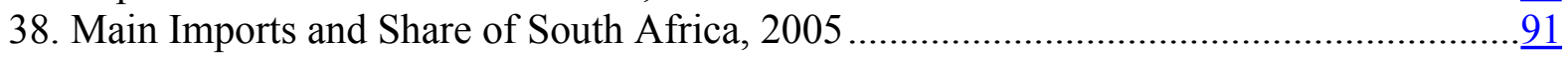

39. Commercial Banks' Performance Ratios, Dec. 2003-07 ................................................

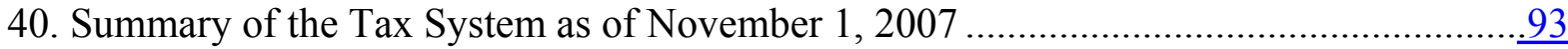




\section{SWAZILAND: BASIC DATA}

Area (square kilometers )

Population (2006)

Population growth rate (2006) in percent

Formal employment (2005)

IMF Position (Janurary 3, 2008)

Quota

Fund holdings of emalangeni

Holdings of SDRs

Exchange rate as of November 30, 2007
17,364

$1,146,050$

1.7

92,102

SDR 50.70 million

SDR 44.15 million

SDR 2.48 million

US\$1 = E 6.81

\begin{tabular}{|c|c|c|c|c|c|c|}
\hline & 2001 & 2002 & 2003 & 2004 & 2005 & 2006 \\
\hline \multicolumn{7}{|l|}{ National income and prices } \\
\hline GDP at constant prices & 0.9 & 2.2 & 3.8 & 2.6 & 2.4 & 2.8 \\
\hline GDP per capita at constant prices & -1.7 & -0.4 & 1.3 & 0.4 & 0.4 & 1.1 \\
\hline GDP deflator & 6.9 & 8.1 & 6.0 & 3.4 & 4.8 & 5.3 \\
\hline CPI (period average) & 7.5 & 11.7 & 7.4 & 3.4 & 4.8 & 5.3 \\
\hline $\mathrm{CPI}$ (end of period) & 10.8 & 11.5 & 4.6 & 3.2 & 6.3 & 5.5 \\
\hline \multicolumn{7}{|l|}{ External sector } \\
\hline Current account balance (millions of U.S. dollars) & -56.8 & 57.6 & 124.2 & 51.7 & -81.4 & -80.8 \\
\hline Export volume, f.o.b. & 51.3 & 19.7 & 0.6 & 34.4 & -15.4 & -4.0 \\
\hline Import volume, f.o.b. & 38.5 & -5.5 & -15.4 & -1.9 & -1.4 & -1.7 \\
\hline Real effective exchange rate ${ }^{1}$ & -11.0 & 6.0 & 13.0 & 3.0 & 1.7 & -5.2 \\
\hline \multicolumn{7}{|l|}{ Money and credit ${ }^{2}$} \\
\hline Broad money & 10.7 & 13.1 & 14.1 & 10.4 & 5.9 & 25.1 \\
\hline Domestic Credit & -13.7 & 58.3 & 34.4 & 30.9 & 10.3 & -3.4 \\
\hline Central government (net) ${ }^{3}$ & -16.7 & 42.1 & 13.1 & 4.8 & -5.4 & -25.2 \\
\hline Private sector & 3.0 & 16.2 & 21.3 & 26.1 & 15.7 & 21.8 \\
\hline Prime lending rate (percent; end of period) & 12.5 & 16.5 & 11.5 & 11.0 & 10.5 & 12.5 \\
\hline Interest rate on 12-month time deposits (percent; end of pe & 6.3 & 9.5 & 4.2 & 4.1 & 3.5 & 8.5 \\
\hline Discount rate (end of period) & 9.5 & 13.5 & 8.0 & 7.5 & 7.5 & 9.0 \\
\hline Gross national savings & 13.3 & 24.7 & 25.6 & 20.6 & 14.8 & 14.0 \\
\hline Of which: government & 5.0 & 3.0 & 3.4 & 3.6 & 6.5 & 12.8 \\
\hline Gross domestic investment & 17.6 & 19.9 & 18.8 & 18.4 & 18.0 & 16.9 \\
\hline Of which: government & 7.7 & 7.5 & 5.9 & 8.2 & 8.5 & 7.5 \\
\hline \multicolumn{7}{|l|}{ Central government finances (fiscal year) ${ }^{4}$} \\
\hline Total revenue and grants & 26.8 & 26.7 & 27.6 & 30.9 & 32.0 & 41.5 \\
\hline Of which: South African Customs Union (SACU) receipts & 12.9 & 12.6 & 13.3 & 17.7 & 18.1 & 27.5 \\
\hline Total expenditure and net lending & 29.7 & 31.3 & 30.4 & 35.5 & 33.5 & 31.3 \\
\hline Current expenditure and net lending & 21.9 & 23.7 & 24.3 & 27.4 & 25.7 & 24.1 \\
\hline Central government balance (including grants) & -3.0 & -4.6 & -2.9 & -4.6 & -1.5 & 10.2 \\
\hline Primary balance (including grants) & -2.1 & -3.3 & -1.6 & -3.5 & -0.4 & 11.0 \\
\hline Government debt & 23.9 & 21.8 & 22.3 & 17.8 & 15.9 & 16.8 \\
\hline Non-SACU fiscal balance & & & & -22.3 & -19.6 & -17.4 \\
\hline \multicolumn{7}{|l|}{ External sector } \\
\hline Current account balance & -4.3 & 4.8 & 6.8 & 2.2 & -3.1 & -2.9 \\
\hline Trade balance (merchandise goods) & -6.2 & 7.6 & 5.7 & 3.8 & -4.7 & -5.1 \\
\hline Capital and financial account balance & -9.4 & -12.5 & 2.8 & -10.5 & 3.2 & 10.2 \\
\hline Overall balance & -4.3 & -8.0 & -3.5 & -1.8 & -0.1 & 5.1 \\
\hline External debt & 21.9 & 29.5 & 22.7 & 20.4 & 16.6 & 15.8 \\
\hline \multicolumn{7}{|l|}{ Memorandum items: } \\
\hline GDP in current prices (millions of emalangeni) ${ }^{5}$ & 11,334 & 12,519 & 13,775 & 15,353 & 16,617 & 18,854 \\
\hline Balance of payments (millions of U.S. dollars) & 67 & -100 & 77 & -52 & -7 & 163 \\
\hline Gross official reserves (millions of U.S. dollars) & 267 & 260 & 265 & 262 & 231 & 364 \\
\hline (months of imports of goods and nonfactor services) & 2.4 & 2.7 & 2.1 & 1.5 & 1.3 & 2.2 \\
\hline Net official international reserves (millions of U.S. dollars) & 228 & 235 & 202 & 258 & 240 & 324 \\
\hline (months of imports of goods and nonfactor services) & 2.0 & 2.5 & 1.6 & 1.5 & 1.4 & 2.0 \\
\hline Total external debt (millions of U.S. dollars) & 288 & 351 & 413 & 485 & 435 & 441 \\
\hline \multicolumn{7}{|l|}{ Sources: Swazi authorities; and IMF staff projections. } \\
\hline \multicolumn{7}{|l|}{${ }^{1}$ IMF Information Notice System trade-weighted; end of period. } \\
\hline \multicolumn{7}{|c|}{${ }^{2}$ Data for 2007 pertain to the latest available actual information-September 2007.} \\
\hline \multicolumn{7}{|c|}{${ }^{3}$ Includes government holdings abroad. } \\
\hline \multicolumn{7}{|l|}{${ }^{4}$ The fiscal year runs from April 1 to March 31.} \\
\hline${ }^{5}$ The official GDP numbers from 1994 to 2006 y & & & & & & \\
\hline
\end{tabular}




\section{Swaziland: Fiscal Policy and Sustainability ${ }^{1}$}

\section{A. Introduction}

1. In the late 1990 s in Swaziland public finances deteriorated, although it had recorded sizable surpluses for much of the 1980s. The combination of expansionary public spending and declining revenues caused budget deficits. The considerable spending did not facilitate growth and did not benefit the poor. More recently, however, with augmented revenues from the Southern African Customs Unions (SACU), ${ }^{2}$ the fiscal situation has reversed even though spending has continued to grow. In the next few years, SACU revenues are likely to remain high because the South African economy is expected to perform well. Spending is also expected to increase substantially in line with the authorities' medium-term budget policy statement, 2008/09-2010/11, although domestic revenues will remain stagnant. Unfortunately, since most of the increase will be on current expenditures related to wages, transfers, and subsidies, growth is not likely to increase substantially.

2. The threat of falling SACU revenues in the medium term and the continued high spending pose risks for fiscal sustainability. This paper therefore proposes an alternative indicator to assess fiscal performance. The indicator would be a non-SACU fiscal balance that could provide policy makers with a less volatile tool by focusing on generating domestic revenues compatible with fiscal sustainability. A fiscal stance based more on domestic taxes and less on trade-related sources could provide enough resources to promote growth and prioritize social spending on health and education.

3. With credible political commitment, fiscal sustainability could be achieved with a combination of expenditure-reducing and revenue-enhancing measures. The measures would be complemented by firming up management of public finances and adhering to the medium-term fiscal framework. The measures could generate resources both to increase public investment and trigger more private sector participation.

4. In what follows, Section B reviews fiscal performance for 1996-2007. It also highlights the effects of fiscal spending on investment and growth. Section $\mathrm{C}$ describes the medium-term outlook for fiscal policy and growth. Section D discusses the non-SACU fiscal balance. Section E deals with the need to achieve fiscal sustainability to boost growth, by introducing revenue-enhancing and expenditure-cutting measures. Section F highlights the importance of effective public expenditure management to fiscal credibility, and Section $\mathrm{G}$ draws conclusion.

\footnotetext{
${ }^{1}$ Prepared by Alfredo Torrez.

${ }^{2}$ As a SACU member Swaziland receives a share of the SACU revenue pool, which is comprised of tariffs and excise taxes collected in the region.
} 


\section{B. Fiscal Performance 1997-2006}

5. In the late 1990s Swaziland started registering fiscal deficits owing mainly to growing expenditures, both recurrent and capital. The overall deficit including grants increased from 1.1 percent of GDP in 1996/97 to more than 4.5 percent of GDP in 2004/05. The deficits were financed primarily by drawing down international reserves, issuing domestic debt, and to a lesser degree borrowing from abroad. However, in spite of the increasing spending, economic

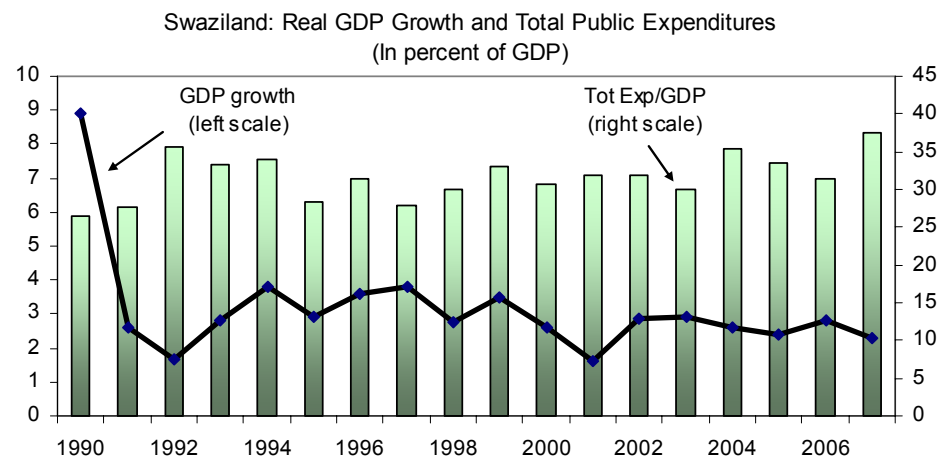
growth slowed from an annual average of 3.6 percent in the 1990s to just over 2 percent since 2000 .

\section{Expenditures}

6. Total expenditures increased from 24 percent of GDP in 1996/97 to more than 31 percent in 2006/07. A major reason was the wage bill, which increased from about 10 percent of GDP to 14 percent. Wage expenditures have grown by about 10 percent in real terms since 2004. Transfers and subsidies also rose to support: (i) the operations of some stateowned enterprises (SOE), including the Central Transport Administration; (ii) subsidies to health clinics; (iii) grants for tertiary education; and (iv) transportation and official travel.

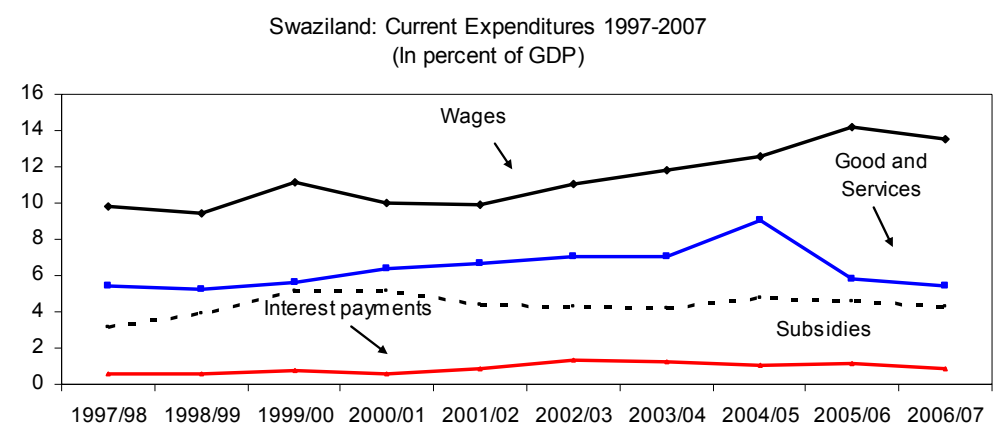

7. Despite the continued fiscal expansion and extensive poverty-69 percent of the population lives on less than US\$1 a day-expenditure on social sectors is low by regional standards. Expenditure on health is behind neighboring countries (Figure I.1), even though Swaziland has the highest prevalence rate of HIV/AIDS. Education outlays lag similarly. Since 2000 budgetary allocations have been kept at about 2.5 percent of GDP for 
health and 6.0 percent for education. Primary universal education is yet to be fully implemented; up to 23 percent of eligible children do not attend school. Even though spending on agriculture has been held at 4 percent of total expenditures and crop production has declined steadily. The result is that about 25 percent of the population require food assistance. The quality of spending also needs to improve so as to target the most vulnerable segments of the population. In spite of the growing recurrent expenditures, the quality of social services for poor households has not improved by much. Food security, which is largely

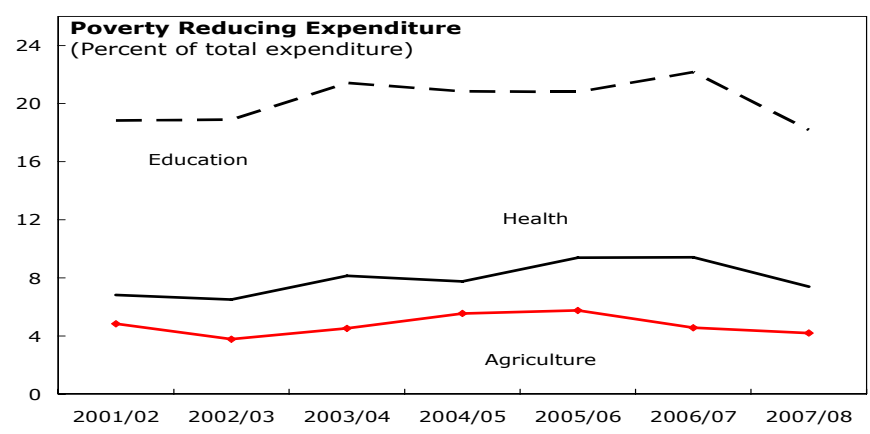
supported by donors, has not necessarily been distributed in a timely and effective manner due to gaps in the distributional organization. ${ }^{3}$

\section{Capital expenditures have been low compared with neighboring countries and} they have been only minimally effective supporting economic growth and poverty reduction. Low capital expenditure implies slower capital accumulation and hence little economic growth. (Figure I.1). In real terms capital spending increased on average by 1 percent annually for 2001/04-2006/07 even as current expenditures grew by 1.5 percent annually. The situation is complicated by low implementation capacity. On average only 82 percent of what the budget envisaged was actually spent. Capital expenditures are mostly associated with large programs, Swaziland: Current and Capital Expenditures 1997-2007 such as the Usuthu upstream (In percent of GDP) development and the Millennium Development Project. ${ }^{4}$ The latter was launched in 2000 to promote faster economic growth. However, not all its components attracted new international and domestic investments - nor were they progrowth.

\footnotetext{
${ }^{3}$ For instance, HIV/AIDS treatments could have been more effective combined with food assistance to the victims.

${ }^{4}$ The Millennium Development project, initially assessed at E2.4 billion, by 2007 had already used E0.9 billion, and it has been estimated that over the next three years an additional E0.6 billion will be needed. It comprises the construction of an airport, sports center, stadium, theme park, trade fair complex, and factory shells. The budget will support completion of the first two projects only; the rest is to be completed with the participation of investors other than the government.
} 
Figure I.1. SACU Countries: Revenue and Expenditure Indicators, 2000-06 (In percent of GDP)
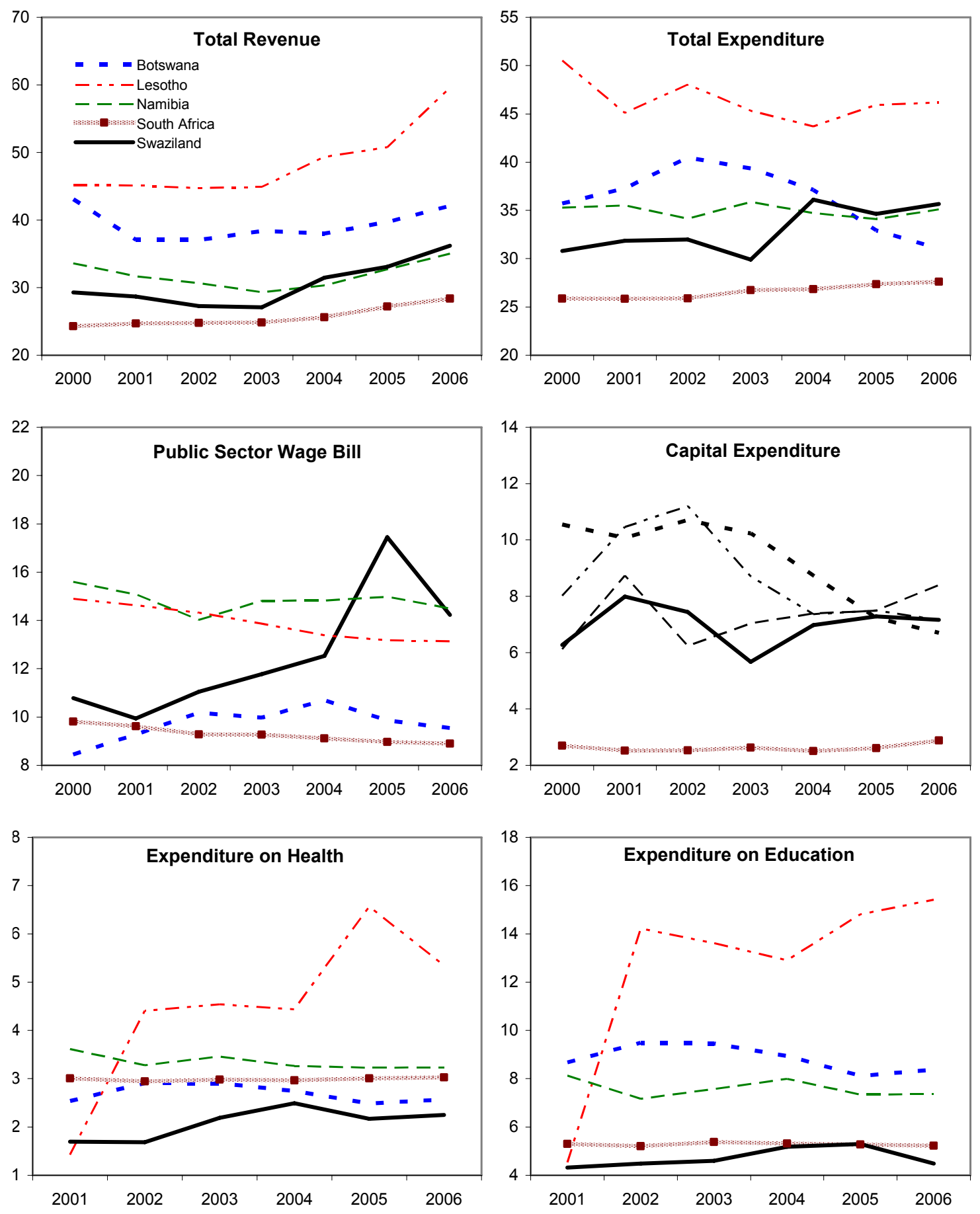

Sources: IMF staff estimates and country authorities. 


\section{The quality of capital expenditure needs improvement to ensure maximization} of social rates of return. Capital expenditures have not been carefully planned, and budget submission by line ministries usually exceeds the capital expenditure ceiling, forcing projects to compete across sectors.

However, project selection is not Swaziland: Capital Expenditure 1997-2007 supported by adequate technical and feasibility appraisals, with the result that financing went to many non-progrowth and non-propoor projects. For instance in 2006/07 up to 50 percent of capital spending was directed toward renovation of public buildings.

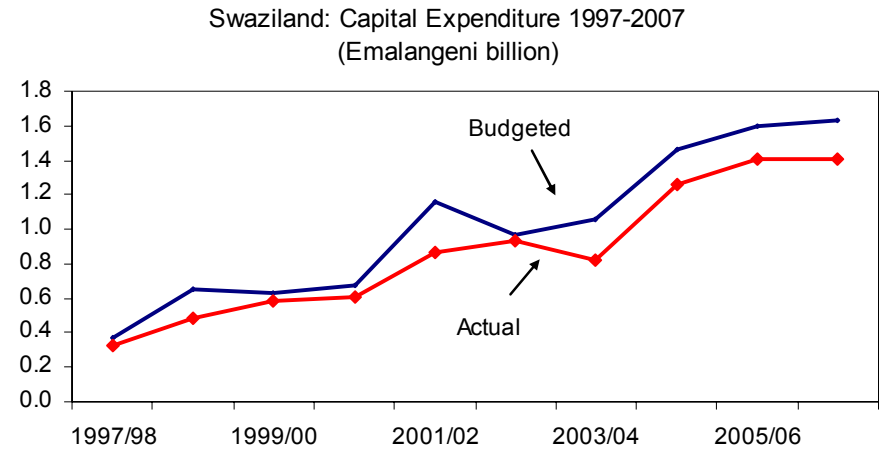

\section{Revenues}

\section{Total fiscal revenues increased from 35 percent of GDP in 1996/97 to more than} 40 percent in 2006/07. ${ }^{5}$ The increase was mainly driven by Swaziland: Fiscal Revenues (1997-2007) SACU revenues, which increased from 15 percent of GDP in $1997 / 98$ to about 28 percent in 2006/07.

Meanwhile, domestic efforts as reflected in tax revenues were almost flat at 12 percent of GDP. Moreover, nontax (In percent of GDP) revenue declined from about 2 percent of GDP in 1998/1999 to less than 1 percent in 2006/07. The share of domestic taxes in GDP is low compared with neighboring countries, and domestic revenue efforts introduced in this period (removal of tax exemptions on rental income, a sales tax amendment to close loopholes, and enforcement of tax collections) did not contribute significantly to government coffers. Moreover, current collection practices are inadequate, and the general sales tax is yet to be replaced by a VAT.

\footnotetext{
${ }^{5}$ SACU revenues contribution to Swaziland's total revenues increased from 40 percent in 1992/1993 to more than 65 percent in 2006/07.
} 


\section{Budget outturn}

11. Since $\mathbf{2 0 0 5}$ and after the introduction of a new SACU revenue-sharing formula, ${ }^{6}$ Swaziland and the other members of SACU have benefited from windfalls. ${ }^{7}$ For Swaziland, these accounted for additional revenues of between 5 and 8 percent of GDP.

12. In 2006/07 there was thus a large surplus after several years of deficits. The overall fiscal surplus (including grants) reached 10.2 of GDP because of augmented SACU revenues reflecting the performance of the South African economy. Moreover, in transforming fiscal performance buoyant SACU revenues have masked the inadequacy of domestic revenue generation. At the same time, spending fell short of budgeted amounts, because the early retirement voluntary scheme for public

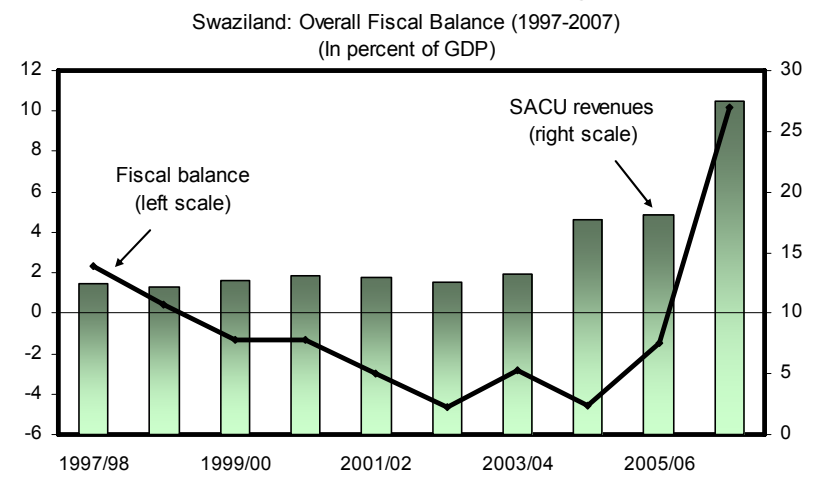
servants was not initiated and payments to the government pension fund were lower. The surplus allowed an accumulation of international reserves to an estimated 3.4 months of imports.

\section{Medium-Term Outlook for Fiscal Policy and Growth}

\section{Fiscal policy and growth}

13. The IMF in 2003 identified as sources of growth in Swaziland capital accumulation, employment, and total factor productivity. ${ }^{8}$ These factors contributed to rapid growth in the 1980s and early 1990s. In particular, capital formation increased significantly from foreign investment as businesses relocated to Swaziland to avoid South African trade sanctions. However, in the
Swaziland: Growth and Investment (In percent of GDP)

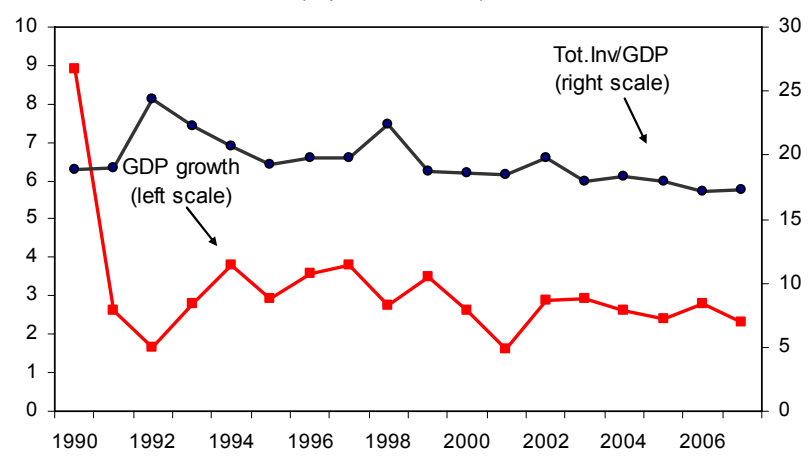

${ }^{6}$ The new formula has the following components: (i) customs, which comprises all customs duties collected by SACU; (ii) excise, which comprises all excise duties collected within SACU; and (iii) development, which has been set at 15 percent of total excise component. The new formula enhances the receipts of the smaller countries.

${ }^{7}$ SACU windfall (or SACU revenue adjustment) is defined as much higher actual SACU payments than estimated, owing to a higher actual value for imports than the one used in forecasting SACU payments.

${ }^{8}$ International Monetary Fund, 2003, Country Report No 3/22, Swaziland, Selected Issues, January. 
late 1990s political changes in South Africa, the emergence of HIV/AIDS, and sluggish and unproductive Swazi public capital investment took a toll on growth by undermining capital accumulation and employment.

\section{Swaziland's economic growth has been low compared with the region and with} other lower- and middle- income countries. Two factors appear to be at work: a slowdown in foreign investments and lower domestic investment as expectations about the economic outlook eroded and reform policies deteriorated. The Poverty Reduction Strategy and Action Plan (PRSAP) estimates that to meet some of the Millennium Development Goals (MDGs) by 2015, Swaziland needs an annual average growth of 5 percent. That is highly unlikely given the current environment.

\section{Swaziland has one of the lowest investment growth rates in the region}

(Figure I.1). This might hinder prospects for overcoming challenges like containing the HIV/AIDS epidemic and meeting the MDGs. Total investment for 1997-2001

Total Gross Capital Formation (In percent of GDP)

was slightly above the sub-Saharan average, but since 2003 it has fallen below the average. While other countries in the region benefited from net foreign inflows, Swaziland has experienced a substantial decline in foreign direct investment since the late 1990s. Total gross capital formation has also headed downward even as neighboring countries have maintained the level of investment in GDP terms. During the high economic growth of the 1980s and 1990s its capital expenditures were on average about 23 percent of GDP. In the last five years they have declined to about 18 percent of GDP, and GDP growth has been about 2 percent.
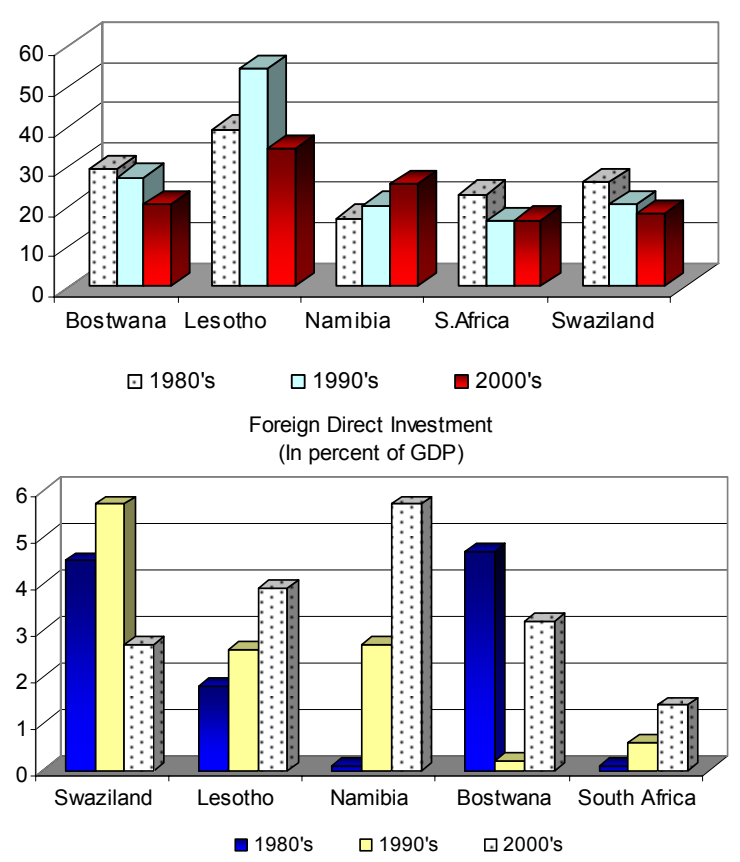

\section{Sound public finances are a prerequisite for growth, but the foundational} economic and policy conditions have not improved sufficiently. Because progress in reforming the economy and strengthening macroeconomic policies has been sluggish, investment dynamics have not improved and growth has decelerated. Elsewhere, rising investments and productivity have underpinned growth, a probable result of efficiency gains from structural reforms, improvements in the business climate, and better economic policies. To facilitate growth fiscal policy must be more effective to safeguard macroeconomic stability while providing for high-quality public investment, particularly on propoor spending. 
17. The authorities should use fiscal policy to boost growth. Because growth has remained elusive, it is necessary to reorient public spending from nonpriority areas toward higher-yield capital expenditures and areas like health and education that could help restore growth. ${ }^{9}$ High-quality public investment can crowd in private sector initiatives, especially in infrastructure. ${ }^{10}$ The productivity gains required to reach the growth target suggest the need for significant progress in privatizing public enterprises, removing impediments to private activity, reinforcing the domestic financial sector, and improving infrastructure. Spending more on education and health could also boost factor productivity. This could be done by reassigning expenditures from e.g., subsidies to inefficient SOEs, to priority tasks, such as training unskilled workers.

\section{Fiscal outlook 2007/08-2011/12}

18. SACU revenues are expected to remain high at least until 2010. However, Swaziland has not used these resources to steer the economy toward long-term fiscal sustainability. The country needs to restore fiscal discipline and achieve fiscal consolidation to safeguard macroeconomic stability and provide fiscal space to engender growth and reduce poverty.

\section{The main source of fiscal revenues for Swaziland over the medium term will} continue to be SACU revenues, which rely heavily on South Africa's GDP and import level. There could be positive shocks resulting from South Africa's hosting of the 2010 World Cup (WC), which could have spill-over revenue effects for Swaziland. Between 2007-2010 South Africa will spend an estimated R17.4 billion in preparation for the WC, building and renovating WC stadiums, upgrading airports, and transforming urban transport infrastructure. The more than 300,000 foreign visitors expected for the finals are expected to spend about R9.0 billion. ${ }^{11}$ The intended infrastructure investment and the foreign demand seem to reinforce the prospects that the South African economy will grow briskly through 2010. Imports are also forecasted to surge, which would imply higher tariff collection for the customs pool and spillover effects on the fiscal revenues of the other SACU members.

\section{SACU payments as a share of South Africa's GDP were on average about} 0.8 percent of GDP (2000-04). Estimates through 2010 are for an increase to about 1.2 percent of GDP. If that happens annual SACU payments to Swaziland would average about R27 billion. Including the World Cup effect, the SACU pool might thus increase by

\footnotetext{
${ }^{9}$ Studies on the link between higher social or public investment spending and per capital growth found that an increase in capital outlays of 1 percent of GDP increases growth by 0.7 percent over a five-year period. IMF, Regional Economic Outlook, May 2007.

${ }^{10}$ See, e.g., IMF, May 2006,Sub-Saharan Africa, Regional Economic Outlook.

${ }^{11}$ This could prompt hotels in South Africa and the neighboring countries to plan expansion of their accommodation facilities, in particular in cities where some of the participating teams will be staying.
} 
about R78 million a year (2007 to 2011). For Swaziland, whose share of the total pool averages about 20 percent, this could bring in an extra R16-20 million a year $(0.09$ percent of GDP). While the extra revenues would be small, the estimate confirms that SACU revenues for Swaziland would continue to be high through 2010/11, (Appendix I) after which they might be subject to declining pressures from factors like increasing trade liberalization. To consolidate the fiscal space and achieve a sustainable fiscal path, the authorities must therefore work to generate more domestic revenues and target spending prudently toward a sustainable fiscal path.

\section{Fiscal outlook}

\section{Increasing SACU revenues have facilitated a brisk expansion in government} spending that could undermine the stability of the economy in the medium term. A balanced budget is expected for 2007/08 despite anticipated record expenditures of 37.6 percent of GDP, with a further rise in the wage bill to 14.4 percent of GDP. Mediumterm budget policy through $2010 / 11$ is again largely expansionary. The authorities plan to increase spending on education, heath, and agriculture in order to reach some of the MDG's. ${ }^{12}$ If they do, however, without offsetting cuts total spending could rise to a record 39 percent of GDP starting in 2008/09, with the wage bill escalating to above 15 percent. Even allowing for some expected improvements in domestic revenue collections, the projected decline of SACU revenues would bring about a deficit of almost 7 percent of Swaziland GDP by 2012/13.

\section{Nevertheless, the possible} impact on growth of the increased spending will probably be limited. Most will be channeled to recurrent expenditures with a large share to the wage bill. ${ }^{13}$ And over the last three decades private gross capital formation has consistently declined, compared to other countries in the region, considerably affecting growth prospects.

\section{Fiscal policy can become more}

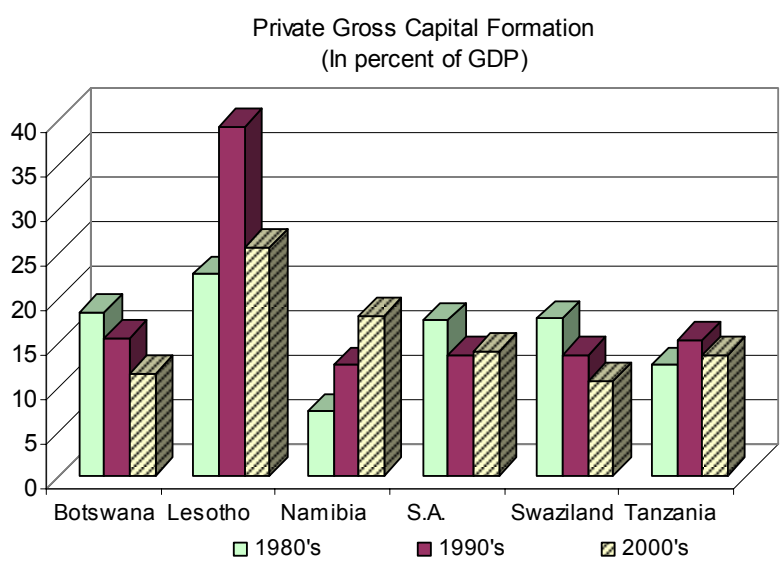
complicated as SACU revenues increase and the government scales up the spending

\footnotetext{
12 The draft Comprehensive Agricultural Strategy, if implemented properly, would help address the food security situation by boosting agriculture production (improving yields through irrigation programs). Most of the spending on food security is financed by donors.

${ }^{13}$ Expenditures on health and education could be growth-enhancing, but much will depend on the quality of spending.
} 
associated with hiring workers, delivering services to the public, and maintaining new infrastructures. Swaziland must now decide what to do when SACU revenues dry up. If the government finds it difficult to reduce expenditures, especially on wages, the pressure for deficit financing could undermine macro-stability. This scenario underlines the importance of formulating a prudent and sustainable fiscal path for the country after SACU revenues fall to more normal levels.

\section{The Non-SACU Fiscal Balance}

24. To better assess the performance of fiscal policy by giving a sharper focus to the domestic revenue effort and a financeable expenditure path, a non-SACU fiscal balance would be a preferred indicator. ${ }^{14}$ This measure will help to put in context the current fiscal surpluses that have engendered higher spending. The non-SACU indicator would be similar to that used by mineral-rich countries that experience sudden inflows to derive a sustainable fiscal stance. It would capture the extent to which the government uses SACU windfalls to finance an increase in expenditure or a reduction in taxation. The indicator would provide policy makers with a less volatile tool (one that eliminates factors that are not fully under their control, such as the performance of the South African economy), while focusing on generating domestic revenues to achieve a non-SACU deficit compatible with fiscal sustainability. Moreover, the indicator will facilitate measurement of the economic impact of the augmented SACU revenues, since the overall fiscal balance, though in surplus, does not truly portray the fiscal stance (e.g., while the overall fiscal balance indicates an average surplus of 3 percent of GDP between 2005/06 and 2007/08, the non-SACU fiscal deficit is an average of 20 percent of GDP).

25. The adoption of a medium-term fiscal framework based on a non-SACU fiscal balance will help policy makers focus on a sustainable fiscal stance. Budgetary projections based on a non-SACU deficit would minimize the downside risks to SACU revenues over the medium term and ensure fiscal sustainability, by allocations for saving during the years of above-trend SACU revenues and then, using savings to smooth spending when that falls.

26. A sustainable non-SACU fiscal deficit could be based on a median of SACU revenues for 1996/97-2004/05, before the recent surges. This "normal" SACU revenue is about 14 percent of GDP. Sustainability was implied by the relatively low debt/GDP ratio for the period that did not create an unbearable burden to the economy, and a sufficient level of international reserves to support the peg.

27. On this basis, estimates of a non-SACU sustainable fiscal deficit would be about 16 percent of GDP. Any SACU revenues above 14 percent of GDP could be used for

\footnotetext{
${ }^{14}$ Defined as the overall fiscal balance less SACU revenues.
} 
progrowth capital investments, propoor priority expenditure, and building international reserves while better projects to boost growth are being identified. Targeting the non-SACU revenues will also give the authorities the space they need to implement domestic revenueenhancing measures. Otherwise, if policies are unchanged, the non-SACU deficit will continue to deteriorate, leading to a deficit of 26 percent of GDP by 2012/13, accelerating debt levels, crowding out the private sector, and speedily depleting international reserves.

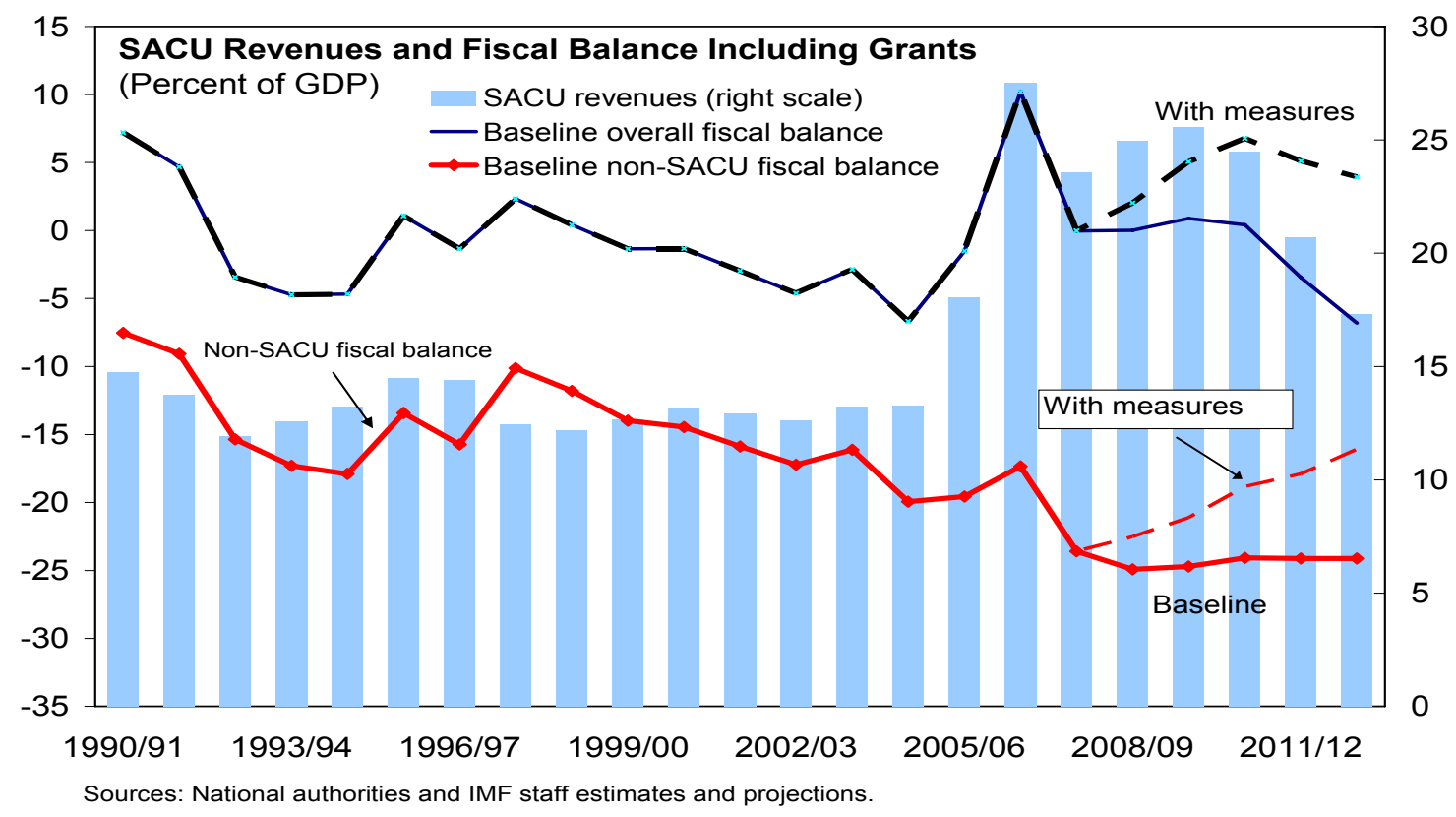

\section{E. Fiscal Sustainability}

28. Fiscal sustainability is usually linked to sound economic fundamentals. Fiscal sustainability can be restored by implementing measures to boost domestic revenues and reduce expenditures, targeting a non-SACU fiscal deficit of about 16 percent of GDP over the medium term. This should put public finance on a path conducive to growth. Revenues higher than the target may be used to boost progrowth capital expenditures and recurrent expenditures that are compatible with the PRSAP.

\section{Durable fiscal adjustment has been found to rely primarily on reducing}

expenditures. ${ }^{15}$ Reducing capital and current spending equally, with emphasis on a durable lowering of the wage bill, worked best. There are also cases of durable fiscal adjustments based on revenue enhancement, particularly for countries with low initial revenue-to-GDP ratios where the pace of adjustment was more gradual. This allowed for sustained implementation over time of tax policy and administrative reforms.

\footnotetext{
${ }^{15}$ IMF, 2006, Experience with Large Fiscal Adjustments, Occasional Paper 246.
} 
30. Large fiscal adjustments generally had a positive macroeconomic impact, and more gradual implementation seems to have brought more favorable economic outcomes. Large adjustments - over 5 percent of GDP — have occurred relatively often over the past 30 years, including in Swaziland in 1974, 1979, and 1987. This time Swaziland would need to introduce measures to reduce expenditures by about 6 percent of GDP over five years.

\section{Revenue reform}

31. To offset the projected decline in SACU revenues, the authorities should take prompt action to generate more domestic revenue. At about 12 percent of GDP tax collection is low compared with other countries. The authorities should introduce measures to strengthen tax collection, establish large-taxpayer units, broaden the tax base, introduce the VAT, and establish a Revenue Authority. The impact of these measures would probably be small in 2008/09 (0.2 percent of GDP) but could increase to more than 2.0 percent of GDP by 2012/13 (Appendix II).

32. If Swaziland were to adopt a VAT rate similar to that in South Africa (at 14 percent), that could yield the equivalent of about 6.8 percent of GDP (the current yield in South Africa). This would be about 3 percent of GDP higher than the revenues currently generated by sales taxes (3.5 of GDP on average). Thus, introducing a VAT could partially offset the revenue decline when SACU income decreases over the medium term.

\section{Expenditure reform}

Wage policy and civil service reform

33. The continued escalation of the wage bill extracts resources from priority spending and uses almost all the domestic revenue collected. The high civil service wage bill is the result of both higher employment and wage growth. Although a civil service reform was approved in 2004/05 that would have eliminated 3,000 positions in three years, the number of government employees has increased from 25,000 to 30,000. Nominal wages have also increased at a rate equal to or above inflation rates. The wage bill is now among the highest in Africa. 


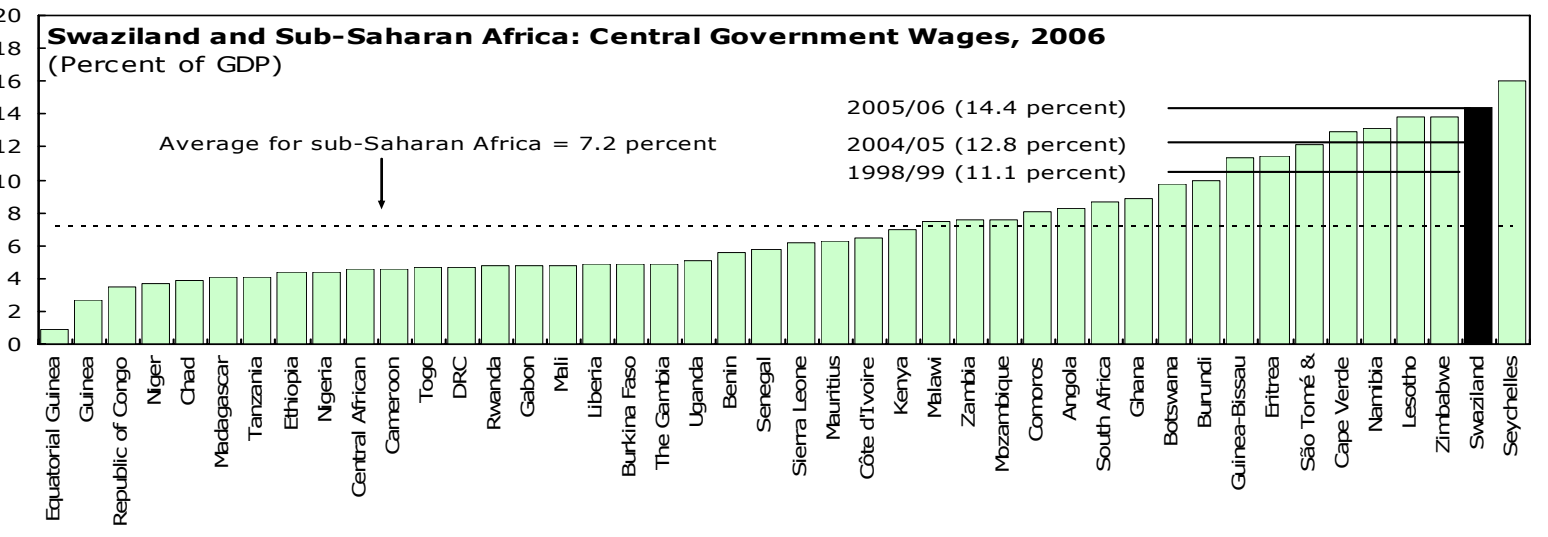

34. Moreover, higher public wages may increase pressure on private wages. Since a large part of social sector employment (education and health) is in the public sector, when public sector wages rise, the pressure to raise wages elsewhere in the domestic economy (for example, manufacturing) may also rise; higher manufacturing wages could reduce export competitiveness. An excessive wage bill also makes the budget more rigid and more vulnerable to shocks. Studies on experience with large fiscal adjustment indicate numerous cases where unsustainable wage bills contribute to fiscal crisis.

\section{There are short-term options for containing the wage bill and reducing the size} of the civil service. Among them are combining attrition with a selective hiring freeze; better centralizing recruitment; regularly auditing the payroll system to maintain its integrity; and avoiding across-the-board salary increases. The pay scale should be decompressed gradually to facilitate recruitment and retention of skilled personnel. To improve budgetary transparency and decision making, in-kind benefits and allowances should gradually be merged into the pay scale.

\section{Other expenditure adjustments}

36. The $\mathbf{2 0 0 4}$ privatization policy still needs to be translated into action. Meanwhile, improving oversight of SOEs to avoid excessive subsidies and transfers, needs to be given priority. ${ }^{16}$ Over the medium term privatization of SOEs can significantly reduce spending while it can potentially reduce service costs and generate private sector activities. Other adjustments should include streamlining foreign travel and transportation costs, eliminating unproductive transfers, reducing subsidies to tertiary education, and to a lesser degree cutting back on goods and service. The World Bank's study indicates that in 2004/5 official foreign travel accounted for more than the entire budget for primary education.

\footnotetext{
${ }^{16}$ On average the government spends about 4 percent of GDP on transfers and subsidies. Since the financial situation of the SOEs depends on pricing, the government should allow pricing practices in accordance with a market mechanism that calls for a move to full cost recovery in a timely fashion.
} 
37. The authorities could reorient expenditures to those that best support private sector driven-growth and poverty reduction. The budget proposal should be aligned to the goals of the PRSAP. ${ }^{17}$ Decisive actions to reduce wage bills, unproductive spending on goods and services, and on subsidies and transfers to SOEs would help to reduce current expenditures by about 2.4 percent of GDP in 2008/09 and 6.0 percent by 2012/13 (Appendix II).

38. The investment climate could be enhanced by reducing the role of the government in the economy. When the public sector is ill equipped to expand its delivery services, an alternative is to work with the private sector. Public-private partnerships could also be explored. But it is important to ensure that such arrangements are adequately monitored and that costs and benefits are carefully analyzed.

\section{F. Fiscal Management and Fiscal Credibility}

39. How effective public expenditure spending is depends on the quality of both policies and institutions. Efficient use of government resources is critical, supported by sound public financial management and good governance. Dealing with Swaziland's remaining challenges in the public expenditure management (PEM) area will require political buy-in for reform at all levels of government to ensure efficient use of limited public resources.

\section{Public expenditure management}

40. If spending is to be productive in achieving growth and reducing poverty, PEM must be able to control and monitor its effectiveness. It is well known that weak policies and institutions, as well as risks of conflict and political instability weigh heavily on many countries with low growth.

\section{The World Bank's 2006 Public Expenditure Review (PER) found that PEM in} Swaziland suffers from systemic weaknesses in most critical stages of the budget process. The PER stresses the need to improve budget preparation, budget execution, reporting and transparency, and coordination with donors. Other areas needing work are management of commitments and prevention of arrears, payroll controls, internal and external audits, and quality of reporting. Unfortunately, a major factor behind poor performance is limited capacity at all levels of government. Well-focused technical assistance could help deal with this issue. The budget exercise, for instance, is distorted by enactment of supplementary budgets to cover unbudgeted expenditures by line departments. Strict adherence to budgetary rules would prevent future arrears.

\footnotetext{
${ }^{17}$ The PRSP also proposes far-reaching reforms to restore macroeconomic stability and boost economic growth.
} 
42. Improvements in the computerized commitment control system have somewhat strengthened PEM, but more comprehensive monitoring is needed. The system prevents budget overruns through a computerized commitments control system. However, not all spending categories (e.g., transfers) and budgetary units (regional administrations and local governments) are automated. Thus, some expenditure arrears still take place and need to be resolved. Furthermore, the ongoing improvement of procurement system, with the assistance of Crown Agents, also plays an important role in ensuring efficient use of budget. Better PEM is crucial for a successful fiscal adjustment.

43. Better PEM is crucial for a successful fiscal adjustment. Weak controls on line ministry expenditures have caused budget overruns and accumulation of arrears. Containing the fiscal deficit will necessitate improved budget discipline and accountability, reform of the public procurement system, and firmer control of expenditure commitments, as the PER envisages. The authorities need to strengthen formulation, execution, and monitoring of the medium-term expenditure framework to enhance fiscal transparency.

\section{Medium-term fiscal expenditure framework (MTEF)}

44. The MTEF needs to be reinforced. Introduced in 2003/04 as part of the fiscal restructuring project financed by the European Union, it has guided the ministry of finance and line ministries in preparing a three-year budget outlook on which one-year budgets are based. Still needed, however, are a public expenditure tracking system aligning the annual budget with the PRSA and better project evaluation. The monitoring system should also cover delivery of services.

45. The improvements in the transparency, quality, and depth of the budgeting process for ministries and departments envisaged by the MTEF would allow for better prioritization of spending. The composition of current expenditure in Swaziland is less growth-enhancing than that in other SACU members. A review of the capital expenditure program is needed to focus on projects directly linked to more productive areas with a high social rate of return (e.g., irrigation programs). Project evaluation is critical for ensuring that public investment projects do not jeopardize debt sustainability; priority should be given to high-return, progrowth, and propoor projects where bottlenecks to be resolved by such projects have been clearly identified.

46. Well-functioning PEM systems and the MTEF help improve governance by ensuring that public resources are used transparently and efficiently. Greater transparency, tighter rules governing budget procedures and reporting, and preparation of medium-term expenditure plans would not only enhance the productivity and accountability of public policy, they could have a positive impact on business climate.

47. Empirical evidence shows that good governance is essential if spending is to be effective. The adverse impact of corruption and poor governance on economic and social outcomes is well recognized Corruption tends to be associated with poorly enforced property 
rights, weak rule of law, and few incentives for productive investment, all which damage economic growth.

\section{G. Conclusions}

48. Although Swaziland has been spending heavily, economic growth has been slow, large increases in recurrent expenditures seems not to have done much for the poor. Fiscal consolidation and improvements in the quality of spending are needed to better facilitate economic growth. Progress on poverty reduction, which still affects much of the population has been scanty because economic growth has been so low. The medium-term fiscal outlook, though expansionary, will not sufficiently promote growth because most of the increases are concentrated on recurrent expenditures. It is necessary to reorient spending toward priority areas like health and education.

49. The authorities should use the opportunity of the current high SACU revenues to implement fiscal measures to secure fiscal sustainability and support economic growth to at least 5 percent per year, as proposed by the PRSAP. Developing fiscal policy stance using the non-SACU balance should help policy makers to put in context a fiscal path that is under their control and provide an estimate of the magnitude of adjustments to secure fiscal sustainability. Hence, a combination of revenue and expenditure measures could be specified. Restarting the stalled civil service reform, overhauling the tax administration, introducing the VAT, privatizing public enterprises, and targeting a nonSACU fiscal balance will all help attain and preserve fiscal sustainability.

50. In the medium term, fiscal consolidation and structural reforms should help improve the business climate, promote private sector growth, and a stronger current account. To support fiscal consolidation the PEM and the MTEF must be strengthened to ensure that fiscal resources are used efficiently and for the purpose they were intended. Timely implementation of all measures might attract donor assistance and concessional financing to support social needs. Implementing structural reforms over the medium term could also improve the perception of the international community toward Swaziland, and lead to higher foreign investment and more efficient public investment. If they do not aim for fiscal consolidation, the authorities could miss an opportunity to have a good fiscal foundation for accomplishing everything that is currently needed. 


\section{Appendix I}

\begin{tabular}{|c|c|c|c|c|c|c|c|c|}
\hline \multicolumn{9}{|c|}{ Swaziland: SACU Revenues ${ }^{1}$} \\
\hline & 2003/04 & 2004/05 & 2005/06 & $2006 / 07$ & $2007 / 08$ & 2008/09 & $2009 / 10$ & $2010 / 2011$ \\
\hline 1. South Africa, GDP (billions of rand) & 1,289 & 1,431 & 1,586 & 1,783 & 2,002 & 2,230 & 2,459 & 2,724 \\
\hline 2. SACU payments (billions of rand) & 9.7 & 13.3 & 14.1 & 25.2 & 24.7 & 28.4 & 32.1 & 36.8 \\
\hline 3. SACU/GDP ( in percent) $(2 / 1)$ & 0.75 & 0.93 & 0.89 & 1.41 & 1.23 & 1.27 & 1.31 & 1.20 \\
\hline 4. Swaziland's SACU share (billions of Emalangani) ${ }^{2}$ & 1.9 & 2.8 & 3.1 & 5.3 & 4.99 & 5.73 & 6.44 & 6.93 \\
\hline 5. Swaziland's SACU share (in percent of total) $(4 / 2)$ & 19.3 & 20.8 & 22.2 & 21.1 & 20.2 & 20.2 & 20.1 & 18.8 \\
\hline \multicolumn{4}{|l|}{ 6. World Cup spending effect on GDP (in percent) ${ }^{3}$} & 0.07 & 0.28 & 0.27 & 0.36 & 0.41 \\
\hline \multicolumn{4}{|c|}{ 7. Estimated SACU increase due to improved GDP (billions of Rand) $(1 * 3 * 6)$} & 0.02 & 0.07 & 0.08 & 0.11 & 0.13 \\
\hline \multirow{2}{*}{\multicolumn{4}{|c|}{$\begin{array}{l}\text { 8. Swaziland's share in new SACU's pool (billions of Rand) }(7 * 20 \%) \\
\text { 9. Forecasted Swaziland's share ( in percent) }\end{array}$}} & 0.004 & 0.014 & 0.015 & 0.023 & 0.027 \\
\hline & & & & & 20.2 & 20.2 & 20.0 & 20.0 \\
\hline \multicolumn{5}{|l|}{ 10. Forecasted Swaziland's share to the pool (in percent) ${ }^{4}$} & 4.99 & 5.74 & 6.42 & 7.36 \\
\hline \multicolumn{5}{|c|}{ 11. Adjusted SACU revenues for Swaziland (billions of Rand) ${ }^{5}$} & 5.00 & 5.75 & 6.44 & 7.39 \\
\hline
\end{tabular}

Sources: South Africa's Treasury Review, Swaziland authorities, and staff estimates.

${ }^{1}$ Data from the South Africa's Treasury Review various issues

${ }^{2}$ Data for fiscal years 2007/08 -2009/10 are from Swaziland's budget estimates.

${ }^{3}$ Spending on infrastructure and estimated spending of foreign visitors

${ }^{4}$ Estimates of Swaziland SACU revenues from data released by South Africa on October 2007

${ }^{5}$ Estimates of Swaziland's SACU revenues including additional World Cup effect 


\section{Appendix II}

\section{Key Measures to Restore Fiscal Sustainability}

In anticipation of SACU revenue decline after 2010/11 that would threaten fiscal sustainability, the following measures should be implemented to consolidate the fiscal stance.

\section{Revenue measures}

Establish a large taxpayer unit by mid-2008 (0.01-0.3 percent of GDP).

Implement the Revenue -Authority bill, and introduce VAT within the following two years (0.1-1.5 percent of GDP).

Simplify the tax structure by eliminating some taxes that are not productive and use staff resources to focus on higher yield taxes.
Restore budget credibility, avoid supplementary budget and eliminate unbudgeted expenditures and arrears

Strengthen expenditure management and procurement system $(0.3-0.9$ percent of GDP $)$.

Implement the voluntary exit retirement scheme, reallocate resources to high priority sectors, and freeze hiring $(0.8-1.8$ percent of GDP).

Prioritize expenditures to support pro-poor and productive projects.

Reduce excessive transportation and foreign travel $(0.1-0.3$ percent of GDP).

Accelerate implementation of privatization programs and approve all pending bills $(0.1-1.1$ percent of GDP).

Reduce subsidies and transfers particularly through improving the operations of the Central Transport Administration (1.5 percent of GDP). 


\section{References}

Budget Review 2007, February 2007, Republic of South Africa, National Treasury.

Central Bank of Swaziland, Annual Report April 2006-March 2007.

Henriksson, Jens, “Ten Lessons about Budget Consolidation,” Bruegel Essay and Lectures Series, 2007.

International Monetary Fund, 2006, Sub-Saharan Africa, Regional Economic Outlook, May and September issues.

International Monetary Fund, 2007, Country Report No 07/278, Ghana: Selected Issues, June (Washington: IMF).

International Monetary Fund, 2003, Country Report No 3/22, Swaziland, Selected Issues, January (Washington: IMF).

Ministry of Finance of Swaziland, Budget Speech 2007.

The World Bank, Swaziland Public Expenditure Review, August 31, 2006, Report No. 35318-SW, (Washington: The World Bank).

Tsibouris, George C.; Horton, Mark A.; Flanagan, Mark J.; Maliszewski, Wojciech S., "Experience with Large Fiscal Adjustment", IMF, Occasional Paper 246, 2006. 


\section{Swaziland’s Financial Sector Development and Future Strategies ${ }^{1}$}

\section{A. Introduction}

1. Swaziland is undergoing a significant change in its financial sector. In recent years, deposit-taking Savings and Credit Cooperatives (SCCOs) have grown substantially and have increased access to finance for many low income individuals. However, growth of SCCOs is taking place without sufficient regulation and supervision, posing risks to the stability of the financial sector. On the other hand, recent reforms that open up the insurance sector to foreign competition and require insurance and pension funds increase their domestic investment holdings have the potential to deepen Swaziland's financial sector, increase its efficiency and boost economic growth, but they also pose regulatory challenges and risks of low returns. The banking system is financially sound and a large fully-owned government commercial bank that received a sizable recapitalization in the past faces a challenging task of meeting a dual objective of being both a commercial and a development bank while competing with other banks that are largely private.

2. Swaziland's shallow financial markets constrain economic growth, resulting in little progress in reducing high rates of poverty and inequality. Experience and research have demonstrated that finance matters for promoting growth, reducing poverty and inequality. However, Swaziland's financial intermediation through the banking system, low by regional and international standards, has actually declined over time using standard measures of banking system depth (Figure II.1). Real per capita GDP growth has fallen from about 3 percent a year over the 1980-1994 period to about 1/2 percent a year since mid-1990s, one of the lowest growth rates in the region and well below low income and lower middle income countries. Meanwhile, high inequality is persistent and poverty has risen from 66 percent in 1995 to 69 percent in 2001 and is perhaps higher today because of lower growth and high unemployment.

\footnotetext{
${ }^{1}$ Prepared by Hamid R. Davoodi.
} 
Figure II.1. Banking Sector Depth and Economic Growth (in percent)

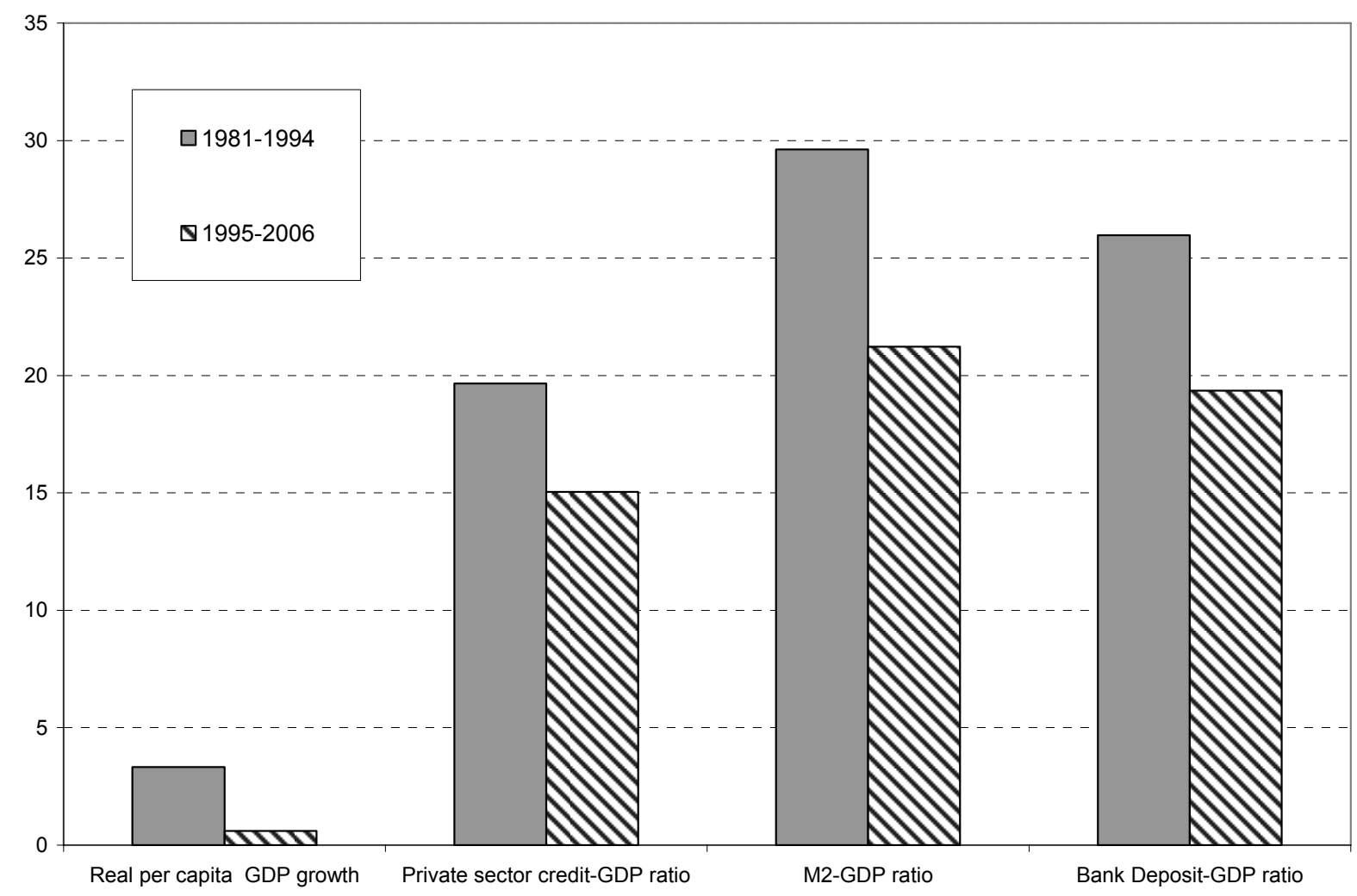

Sources: International Financial Statistics, World Development Indicators, and staff estimates.

3. Financial development and financial stability are therefore two main challenges confronting Swaziland's financial sector. This chapter explores the performance of Swaziland's financial sector using peer group analyses and benchmarking, identifies potential sources of vulnerability and developmental obstacles, reviews ongoing reforms that are to meet the challenges and concludes by discussing steps that could address the major obstacles. ${ }^{2}$ Accordingly, the chapter addresses the following four issues:

- $\quad$ financial structure and soundness;

- $\quad$ financial sector efficiency and profitability;

- $\quad$ key constraints to a deeper and healthier financial system; and

- $\quad$ key elements of a forward looking financial sector strategy.

\footnotetext{
${ }^{2}$ Swaziland has not yet benefited from a Financial Sector Assessment Program (FSAP), but has received considerable technical assistance from the IMF Monetary and Capital markets Department (MCM) and others.
} 


\section{B. Benchmarking and Peer Group Analyses}

4. Peer group analyses is used to assess quantitatively the performance of various aspects of Swaziland's financial sector. Peer group analysis sets out various benchmarks with which Swaziland's financial performance can be compared, including its own past history. It is therefore of particular relevance to the objective of the chapter. The analysis is also helpful for assessing financial stability and financial deepening since an annual regular benchmarking exercise of Swaziland's financial sector against its peer groups can help identify the success of a financial sector strategy and the main constraints in meeting its objectives.

5. That said, Swaziland's performance is benchmarked against several peer groups which offer different insights. The following factors are used to define peer groups: stage of economic development, economic and financial integration as well as a regional focus. Understandably these groups are not mutually exclusive and commonalities will be discussed. Research has shown that financial structure is strongly shaped by stage of economic development as proxied by per capita income (Demirgüç-Kunt and Levine, 2001):

- $\quad$ According to World Bank classification, Swaziland is a lower middle income country. Therefore, the lower middle income group forms a natural peer group to compare Swaziland with;

- $\quad$ The upper middle income and low income groups are two other peer groups, which can be used to determine if Swaziland's financial sector is underperforming vis-à-vis countries with higher per capita income or overperforming relative to countries with lower per capita income, respectively;

- $\quad$ Swaziland is also compared with other African countries with which its has close financial, trade and historical links through the Southern African Customs Union (SACU) - consisting of Swaziland, South Africa, Namibia, Lesotho and Botswanaand the Common Monetary Area (CMA) - the SACU countries excluding Botswana. ${ }^{3}$ The CMA countries provide a natural peer group since as part of the CMA Swaziland's currency is pegged to the South African rand and Swaziland's financial structure is closely integrated with that of South Africa. Moreover, SACU and CMA countries are at different stages of economic development thus allowing for richer benchmarking while controlling for some common factors (a customs union and common currency, respectively); and

\footnotetext{
${ }^{3}$ According to World Bank classification, South Africa and Botswana are upper middle income countries while the remaining SACU countries are lower middle income countries.
} 
- $\quad$ Sub-Saharan Africa (SSA) is the final peer group as it provides a larger regional focus than the SACU and the CMA, and is a distinct group than low, lower and upper middle income groups that cover disparate continents.

\section{Financial Sector and Soundness}

\section{Overview}

6. The financial sector is small, but includes numerous informal financial entities. The financial sector consists of the Central Bank of Swaziland (CBS), four commercial banks, one building society, two unit trusts, two development finance institutions, 56 SCCOs, a stock exchange, over 200 pension funds (private and public), six life and insurance companies, and over 100 micro finance institutions (MFIs). In terms of GDP, as of end-2006, total assets of the financial sector - consisting of banks, SCCOs, pension funds and life and insurance companies - is estimated at 105 percent of GDP as compared with 160 percent of GDP for Namibia at end-2004 and 118 percent of GDP for Botswana at end-2006. ${ }^{4}$ In US Dollar terms, the estimated size of Swaziland's financial sector at end-2006 stood at about US\$3 billion as compared with \$US 10.7 billion for Namibia at end-2004 and US\$12 billion for Botswana at end-2006.

\section{The banking system}

\section{The depth of the Swazi banking system is at the lowest end of the spectrum} among its peer groups based on three widely-used measures of financial depth (Figure II.2). Ratios of M2, M3 and bank deposits to GDP are well below all income groups, the SSA average as well as other members of the SACU. ${ }^{5}$ However, Swaziland's banking sector, as measured by the ratio of private sector credit to GDP — another widely used measure of financial depth - is deeper, exceeding levels recorded by the SSA and low income countries. This overperformance is a recent phenomenon. Between 1998 and 2004, Swaziland's credit-GDP ratio was below both the SSA and low income countries while it has been trending down consistently till 2001. Swaziland's eventual catch-up and overtaking of these groups since 2004 occurred as a result of the combination of low interest rates and strong prospects for Swaziland's textile and sugar industries.

8. However, Swaziland's financial depth, as measured by the ratio of M1 to M2, is comparable to upper middle income countries and South Africa and better than Namibia and Lesotho among SACU countries (Figure II.3; Table II.1). A low ratio of M1 to M2 reflect, among other things, less reliance on cash for transactions, higher reliance

\footnotetext{
${ }^{4}$ Excluding specialized financial institutions (e.g., development banks, agricultural banks) across these countries for which comparable data are not available.

${ }^{5}$ Estimates of M3 for Swaziland includes SCCOs.
} 
on term deposits, a low inflation environment and confidence in the banking system.

Therefore, financial development is generally associated with a decline in the ratio. There has been a steady decline in the ratio across all income categories. At end-2006, Swaziland's ratio is less than half the SSA level while the SSA continues to have the highest ratio in the world. Swaziland's ratio declined from 37 percent in 1980 to 31 percent in 2006 against a much larger decline of 10 percent to 59 percent for the SSA. However, Swaziland's ratio has been rising recently reflecting in part disintermediation from the banking system by SCCOs, which tend to have lower charges and fees than commercial banks and may offer higher interest rates.

Table II.1. Indicators of Financial Depth by Income Group and SACU, 2006

\begin{tabular}{|c|c|c|c|c|c|c|}
\hline & $\begin{array}{c}\text { Bank deposits- } \\
\text { GDP ratio }{ }^{1}\end{array}$ & $\begin{array}{c}\text { Private sector } \\
\text { credit-GDP ratio }^{1}\end{array}$ & M2-GDP ratio & M3-GDP ratio ${ }^{2}$ & $\begin{array}{c}\text { Ratio of M1 to } \\
\text { M2 }\end{array}$ & $\begin{array}{c}\text { Memo: } \\
\text { Gross National } \\
\text { Income per } \\
\text { capita US\$ }\end{array}$ \\
\hline Swaziland & 21.7 & 22.5 & 23.0 & 25.0 & 31.3 & 2,430 \\
\hline Botswana & 33.2 & 19.6 & 32.5 & 40.8 & 21.0 & 5,900 \\
\hline Namibia & 25.0 & 58.4 & 47.9 & 52.2 & 60.8 & 3,230 \\
\hline Lesotho & 30.7 & 8.9 & 30.5 & 35.1 & 76.6 & 1,030 \\
\hline South Africa & 57.4 & 70.7 & 61.4 & 65.8 & 29.7 & 5,390 \\
\hline \multicolumn{7}{|l|}{ Other peer groups } \\
\hline Low income countries & 24.4 & 20.9 & 56.1 & 61.7 & 53.7 & 650 \\
\hline Sub-Saharan Africa & 26.6 & 19.8 & 41.8 & 46.2 & 59.1 & 842 \\
\hline Lower middle income countries & 48.6 & 43.8 & 114.5 & 123.3 & 39.9 & 2,037 \\
\hline Upper middle income countries & 55.8 & 52.3 & 44.9 & 48.4 & 35.1 & 5,913 \\
\hline
\end{tabular}

Sources: Beck, Demirgüç-Kunt and Levine, (2007 updated), "A New Database on Financial Development and Structure" World Bank; World Development Indicators; International Financial Statistics; and Fund staff estimates.

${ }^{1}$ Deposit money banks.

${ }^{2}$ Currency plus demand and interest bearing liabilities of deposit money banks and nonbank financial intermediaries. 
Figure II.2. Indicators of Banking System Depth: Swaziland and Various Peer Groups (In percent)


Source: International Financial Statistics and World Development Indicators. For Swaziland, M3 includes SCCOs. 
Figure II.3. Indicators of Banking System Depth: Swaziland and Other SACU Countries (In percent)
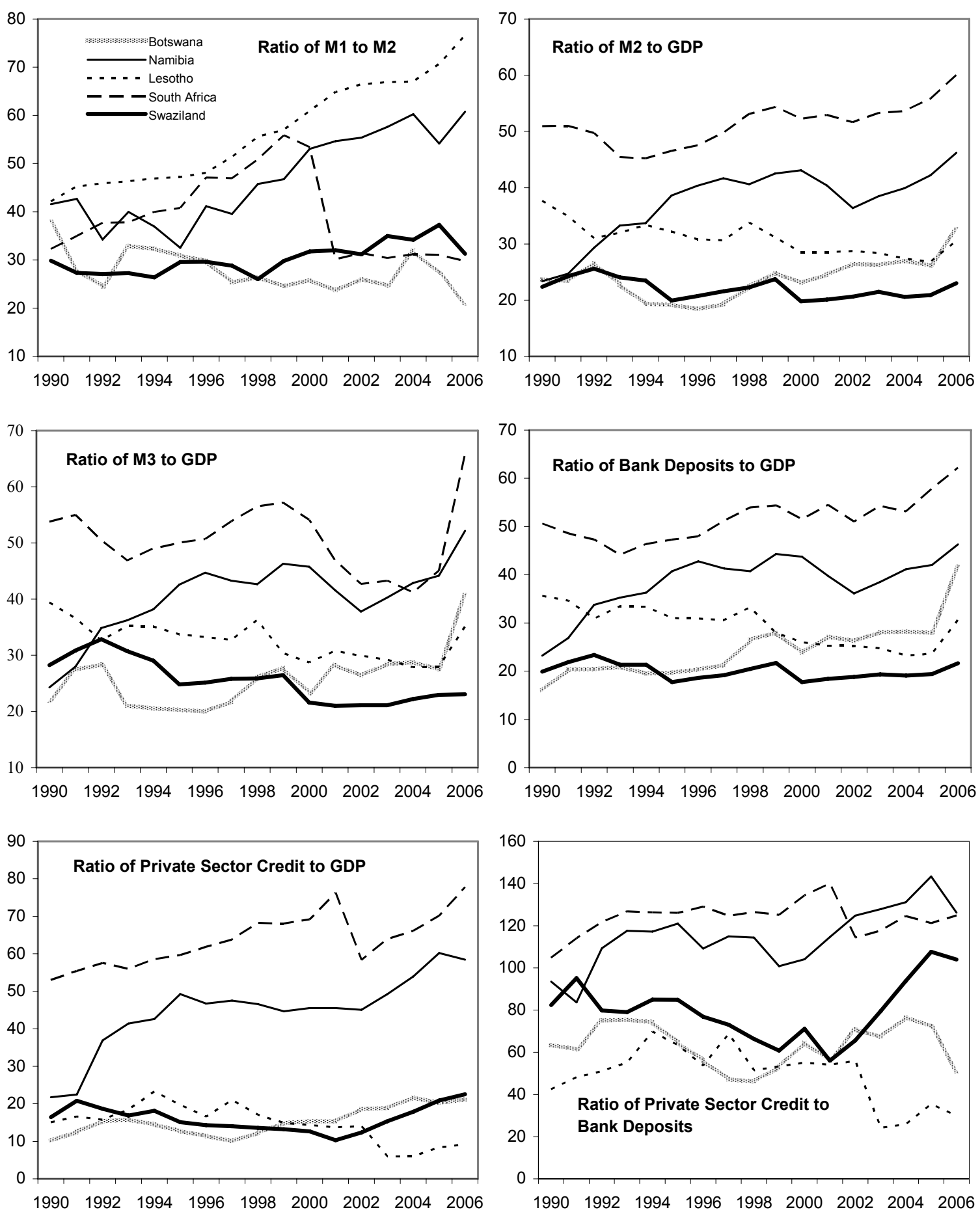

Source: International Financial Statistics, World Development Indicators and staff estimates.For Swaziland, M3 includes sccos. 
9. The banking system is largely foreign owned. Three banks, the Standard Bank, the First National Bank and the Nedbank are subsidiaries of South African banks. The largest bank is the Standard Bank while the government-owned Swazibank is the third largest commercial bank. All commercial banks have branch networks around the country offering both personal and corporate banking services. The Swaziland Building Society is a deposittaking financial institution which offers mortgage loans, accounting for about 80 percent of its loan portfolio, and savings and investment accounts; loans are secured and are mostly residential. All five financial institutions are regulated and supervised by the CBS.

Table II.2. Swaziland's Banks: Ownership Structure and Size

(in percent)

\begin{tabular}{lcccc}
\hline & & Ownership & & Size \\
\cline { 2 - 4 } \cline { 3 - 4 } & Government & Foreign & Public & Asset-GDP ratio \\
\hline Standard Bank Swaziland Ltd & 25 & 65 & 10 & 12.2 \\
First National Bank Swaziland Ltd. & & 100 & & 6.2 \\
Swazibank & 100 & & 10 & 5.7 \\
Nedbank Swaziland Ltd & 23 & 67 & 100 & 5.4 \\
Swaziland Building Society & & & 3.2 \\
\hline
\end{tabular}

Source: CBS Annual Report 2006/07 and Banks' Annual Reports.

10. The Swazi banking system is sound, well capitalized with low nonperforming loans though higher than the rest of the SACU countries. Many banks have low nonperforming loans, except for one bank. The central bank is actively working with the bank to improve compliance. Loans of the banking system are skewed towards sugar-related industries (70 percent of all loans). However, the exposure requirements on large and sectoral-clients are met by all banks. In addition, the three largely South African-owned banks, which have the most exposure to sugar-related industries, conduct regular risk assessments and hedge their risks through their parent companies. 
Figure II.4. Ratio of Nonperforming Loans to Total Loans in SACU Countries in 2006 (in percent)

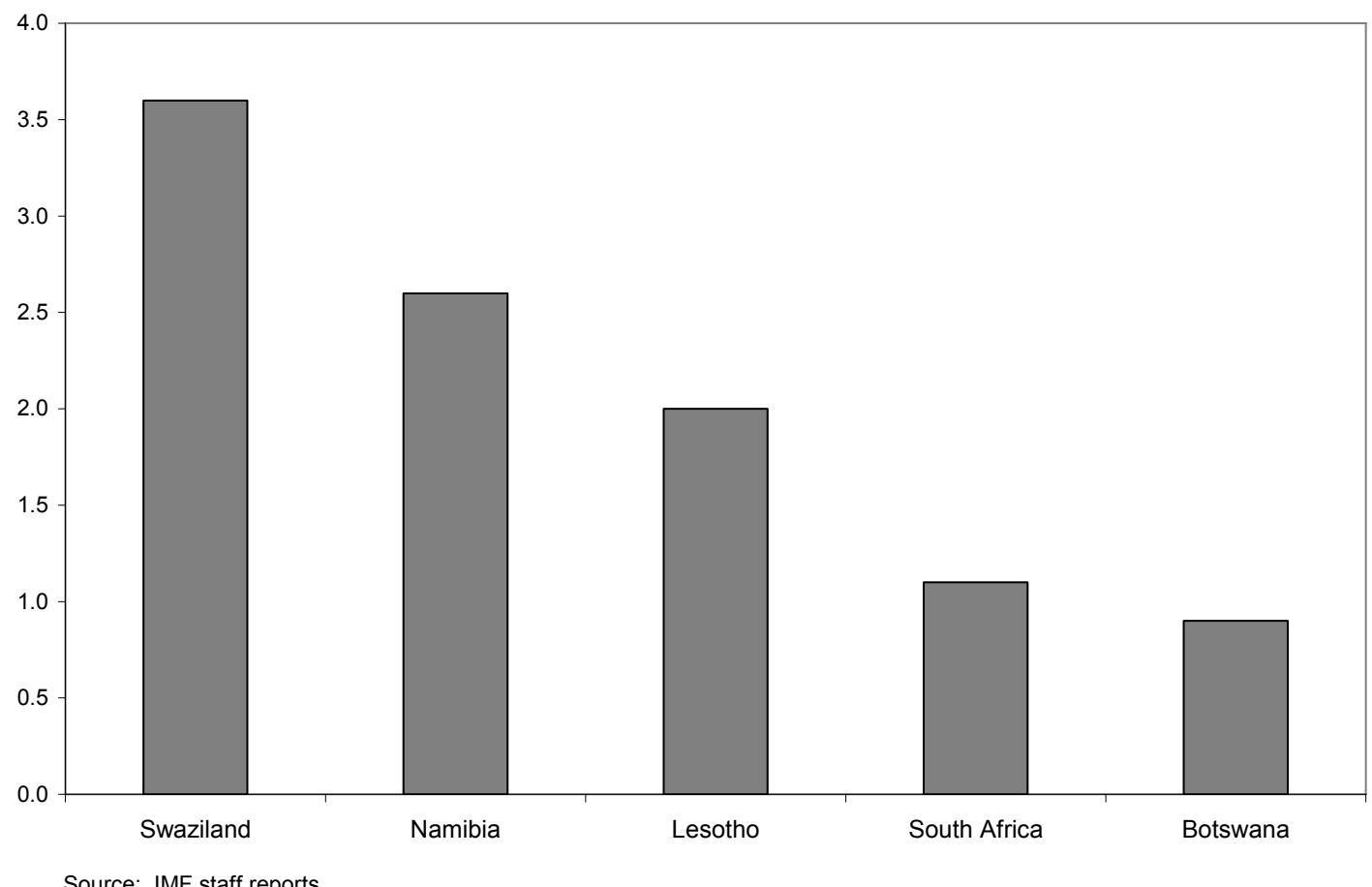

Table II.3. Swaziland: Banking System Prudential Indicators

(in percent)

\begin{tabular}{|c|c|c|c|c|c|c|}
\hline & Dec-2003 & Dec-2004 & Dec-2005 & Dec-2006 & Mar-2007 & Jun-2007 \\
\hline & \multicolumn{6}{|c|}{ (in percent) } \\
\hline \multicolumn{7}{|l|}{ Performance Ratios: } \\
\hline Basle capital ratio (Tier 1 ) & 14 & 14 & 15 & 19.5 & 18.6 & 22.5 \\
\hline Basle capital ratio (Tier 2) & 20 & 16 & 17 & 26.1 & 21.0 & 22.5 \\
\hline \multicolumn{7}{|l|}{ Asset Quality: } \\
\hline Loans to deposit ratio ${ }^{1}$ & 75 & 73 & 83 & 85.5 & 91.5 & 87.9 \\
\hline Earning assets to total assets & 90 & 87 & 92 & 64.5 & 69.2 & 66.7 \\
\hline Nonperforming loans to total loans ${ }^{1}$ & 2 & 3 & 2 & 3.6 & 3.9 & 3.6 \\
\hline Reserve for losses to total loans & 9 & 8 & 7 & 9.6 & 8.5 & 9.2 \\
\hline \multicolumn{7}{|l|}{ Liquidity Ratios: } \\
\hline Liquid assets to total deposits & 19 & 18 & 17 & 20.4 & 17.9 & 19.8 \\
\hline Available reserves to total deposits & 18 & 19 & 20 & 9.9 & 9.7 & 11.7 \\
\hline Liquid assets to total assets & 14 & 14 & 13 & 14.5 & 12.7 & 13.6 \\
\hline \multicolumn{7}{|l|}{ Profitability Ratios: } \\
\hline $\begin{array}{l}\text { Net income to average total assets } \\
\text { (return on assets) }\end{array}$ & 4 & 3 & 3 & 5.9 & 1.5 & 2.5 \\
\hline $\begin{array}{l}\text { Net income to average total equity } \\
\text { (return on equity) }\end{array}$ & 29 & 20 & 20 & 52.0 & 13.4 & 26.0 \\
\hline Total expenses to total income & 60 & 64 & 68 & 70.6 & 73.3 & 73.9 \\
\hline
\end{tabular}

Source: Central Bank of Swaziland.

${ }^{1}$ Excluding the Swazibank, which is owned by the government and offers both development finance and commercial banking services since its recapitalization and reliance by the government in 2001. 
11. Access to finance is limited. According to the World Bank (2007), only 35 percent of the Swazi adult population has access to an account with a financial intermediary. In general access to credit and its availability go hand in hand. However, this does not appear to be the case in Swaziland as it has a higher access than Namibia, but lower ratio of private sector credit to GDP. Similarly, Swaziland has a lower access than Botswana, but higher ratio of credit to GDP. Differences in type of restrictions that limit credit availability, access or both may explain some of these differences.

Figure II.5. Access to Credit

(in percent)



Sources: Word Bank (2007), International Financial Statistics, World Development Indicators, and staff estimates.

\section{The nonbank financial sector: savings and credit cooperatives}

12. The credit cooperative sector in Swaziland was established with a focus on agricultural cooperative concept and is governed by the Cooperative Societies Act (2003) and the Cooperative Societies Regulations (2005) promulgated in 2006. These acts empower Commissioner of the Department of Cooperatives of the Ministry of Agriculture and Cooperatives (MoAC) to regulate and supervise the cooperative sector, including SCCOs. The main responsibility of the Department is to promote and implement the Government Policy on the formation of cooperatives and their development through guidance on the Cooperative Act in line with the National Development Strategy for 
Swaziland to empower its citizens. Responsibility for regulating, monitoring and supervising credit cooperatives rests with the Cooperatives Department, which could be in conflict with its responsibility to promote and develop cooperatives.

13. SCCOs are the more prosperous cooperatives in Swaziland. Fifty five SCCOs were active in Swaziland as of end-2006 with 39,592 members (4 percent of the population): ${ }^{6}$

- $\quad$ Each member is a depositor and can take out a loan only after establishing a history of regular depositing-making to the SCCO, which may take up to two years. SCCOs are formed by workers with a common goal. Examples are the police, army, prison services, hotel service providers, town councils, and teachers;

- At any point in time some cooperatives may can inactive. For example, as of end2006, there were 10 inactive SCCOs and 49 inactive farmers/multipurpose cooperatives;

- $\quad$ SCCOs tend to charge higher interest rates than commercial banks, but have much lower overhead costs, charges and fees and provide credit to individuals who may find it difficult to get access to credit from banks; and

- $\quad$ Some 41 SCCOs are members of Swaziland Association of Savings and Credit Cooperatives (SASCCO), an Apex organization formed under section 40 of the Act, which educates the management of each SCCO and provides training and auditing standards based on best practices as advocated by the World Council of Credit Unions.

\section{SCCOs have grown significantly without sufficient regulation and supervision.}

Their lending and deposit operations have increased from less then $1 / 2$ percent of GDP each in 2002 to $1 \frac{1}{2}$ and 2 percent of GDP, respectively by end-2006. The deposit and lending operations of SCCOs have grown much faster than Swaziland's four commercial banks. Deposits of SCCOs have grown from 3 percent of commercial banks' deposits in 2002 to 10 percent in 2006. Credit extended by SCCOs grew by 116 percent a year since 2002 as compared with 25 percent by banks. SCCOs are required to submit annual audited accounts to MoAC, but MoAC does not seem to scrutinize these accounts systematically. Moreover, some audits do not follow internationally accepted accounting standards. Computers are not used extensively for book keeping though some SCCOs have acquired them recently (e.g., the teachers' SCCO). Monetary accounts currently compiled by the CBS do not include SCCOs.

\footnotetext{
${ }^{6}$ As of end-2006, there were also 60 active farmers/multipurpose cooperatives with an additional 3,549 members. Activities of these cooperatives include consumer shops, vegetable farming, maize production and milling, tractor hire services and sale of farm inputs.
} 
Figure II.6. Swaziland: Lending by Banks and SCCOs
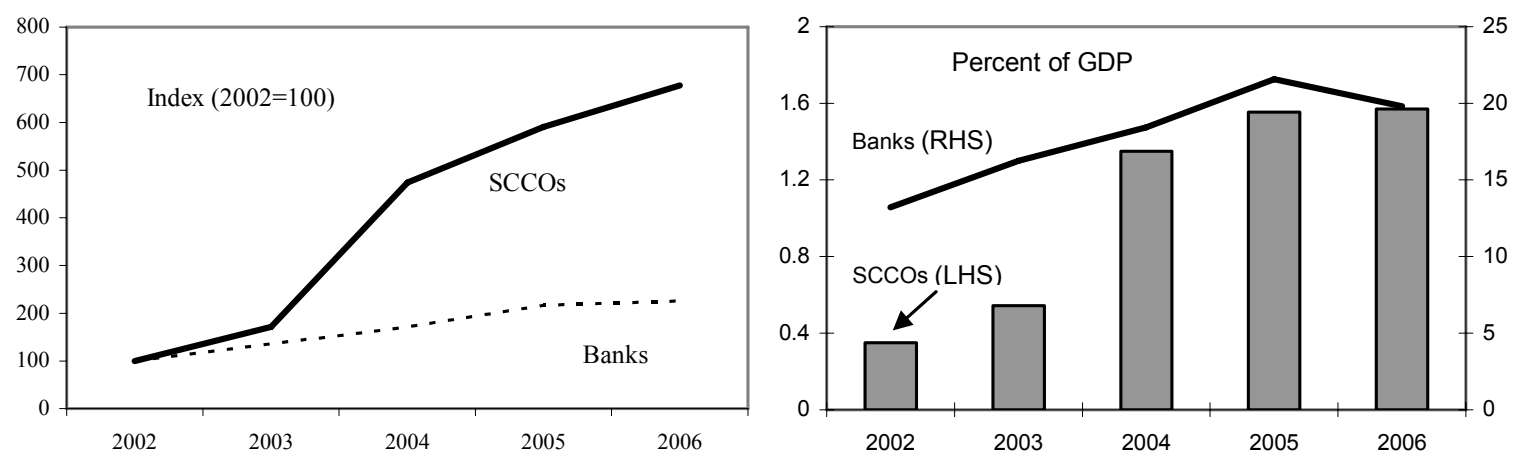

15. SCCOs are highly concentrated in terms of total value of deposits and lending and some face financial difficulties. Prosperous cooperative societies are the SCCOs, which are run more effectively by members who have regular incomes. The top three SCCOs account for almost 50 percent of deposits or lending of all SCCOs. At end-2006, the deposits of SCCOs that may face financial difficulties accounted for almost 1 percent of GDP, equivalent to 4 percent of commercial banks' deposits; their membership is about 2 percent of the population. Currently, no prudential indicators exist for SCCOs.

\section{The nonbank financial sector: pension funds and insurance funds}

16. Pension funds dominate Swaziland's financial sector. There are over 200 pension funds, but the largest funds are Public Service Pension Fund (PSPF) for civil servants and the Provident Fund for the private sector employees. The PSPF alone accounts for almost 55 percent of the financial sector. At end March-2007, its assets stood at E7.4 billion (59 percent of GDP), equivalent to US\$1 billion, which exceeds the combined assets of the four commercial banks. The rate of return on the fund's assets for the financial year ending on March 31, 2007 was 30 percent against 42 percent the previous year with a 10-year historical return of 25 percent. The investment objective of the Fund is to earn at least 5 percent real return on its assets. Under CMA rules, investment managers may invest up to 15 percent of the Fund's assets offshore (i.e., outside the CMA); investments in unlisted shares and unlisted debt instruments may only be made in Swaziland at the discretion of the Board. Between 70 to 85 percent of the assets have to be placed in South Africa, primarily in equities. At its inception in 1991, the Fund was gross underfunded. However, the net actuarial liabilities of the Fund has fallen over time, in large part due to superior investment performance, from E3.2 billion in 2004/05 to E1.4 billion in 2005/06 and to E343 million in 2006/07.

17. Since 2007, the authorities are opening up the local market for insurance and pensions and have enacted a number of legislations. Under the Insurance Act (2005) and the Retirement Act (2005), the Registrar of Insurance Companies and Retirement Funds 
(RIRF) has the responsibility for regulating insurance and pension funds. These acts will provide the framework for creating investment instruments that pension and insurance funds could be invested. Until recently, the insurance market was the monopoly of Swaziland Royal Insurance Company (SRIC). Most life insurance policies were written by South African companies operating via brokers or "briefcase agents" in Swaziland, reflecting the lack of competitiveness of the SRIC. With the passage of supporting regulations of the two acts, five new insurance firms, mostly from South Africa, have entered the local market. The size of the insurance market is estimated at E2 billion (16 percent of GDP) at end-2006.

\section{Established in September 2006, the RIRF is responsible for licensing and} supervising all insurance intermediaries and retirement funds. Few members of the office of the registrar have had any experience in financial system supervision. Technical assistance needs are extensive and MCM has a program in place to assist the authorities.

\section{The legislations require a portion of insurance and pension assets be invested in} Swaziland, starting with 10 percent in November 2007 and rising to 30 percent in three years. The authorities intend to channel domestic savings into the domestic economy, thus spurring investment and deepening capital markets. Over time, this plan is to be supported by privatization of state assets and listing on the stock exchange. Insurers also have to be incorporated in Swaziland, have a physical presence there, and be partly owned by Swazis.

\section{However, at present the opportunities for insurance and retirement funds to} invest their assets locally are limited. The economy is not diverse, the demand for funds by businesses is weak apart from sugar-related industries, and the international financial institutions reportedly offer more attractive terms for infrastructure projects than would be available in the open market. Medium- and long- term debt instruments are unavailable, and the government appears unlikely to create a market by issuing such instruments beyond that needed to finance a residual deficit. The Swazi stock market is small and largely illiquid, limiting domestic investment (see below).

\section{The domestic investment requirement poses certain risks to the financial sector} and real sectors and could complicate the conduct of monetary policy. The requirement could lead to excess liquidity, if funds are repatriated from abroad (primarily from South Africa) and the market is unable to absorb them. The financial performance and solvency of insurers and retirement funds could suffer if high domestic returns are sought with excessive risks. Local incorporation and physical presence requirements could deter some foreign companies from entering the market, limit competition, and increase the operating costs of those that do decide to enter. Each of these risks, if realized, would ultimately have adverse effects on Swazi consumers. Monetary policy also faces challenges. The excess liquidity may get deposited with banks, due to lack of suitable investment vehicles, with the central bank having to mop up the excess liquidity and bear the costs accordingly, which can be large as shown by the experience of other countries with similar requirements (e.g., Botswana). 


\section{The authorities are mindful of these risks and challenges for monetary policy.}

They are exercising flexibility in the application of the requirement while precise regulations are being worked out, including investment of these assets in companies that may be dual listed in Swaziland's Stock Exchange and the Johannesburg Stock Exchange. The central bank is currently taking stock of various options to ensure that liquidity is managed prudently for monetary policy purposes without adverse effects on its balance sheet.

\section{The nonbank financial sector: Swaziland's stock exchange}

\section{The stock exchange is small, illiquid and underperforming relative to regional} stock markets, holding little prospects as an avenue for the domestic investment requirement. The Swaziland Stock Exchange (SSX) was established in 1990 to provide citizens with the opportunity to invest in the economy. There are only six stocks listed on the SSX of which only one is dual listed with the Johannesburg Stock Exchange. At US\$200 million, it has the smallest market capitalization among other SACU countries (South Africa, Namibia, and Botswana) and has been underperforming relative to all. A Security Bill has been in the works since 1993 and is yet to be enacted. Once passed into law, the Bill should promote and facilitate the development of the country's capital market and will empower the authorities to license, authorize, and regulate all securities markets, participants and activities.

Figure II.7. Stock Markets in SACU Countries

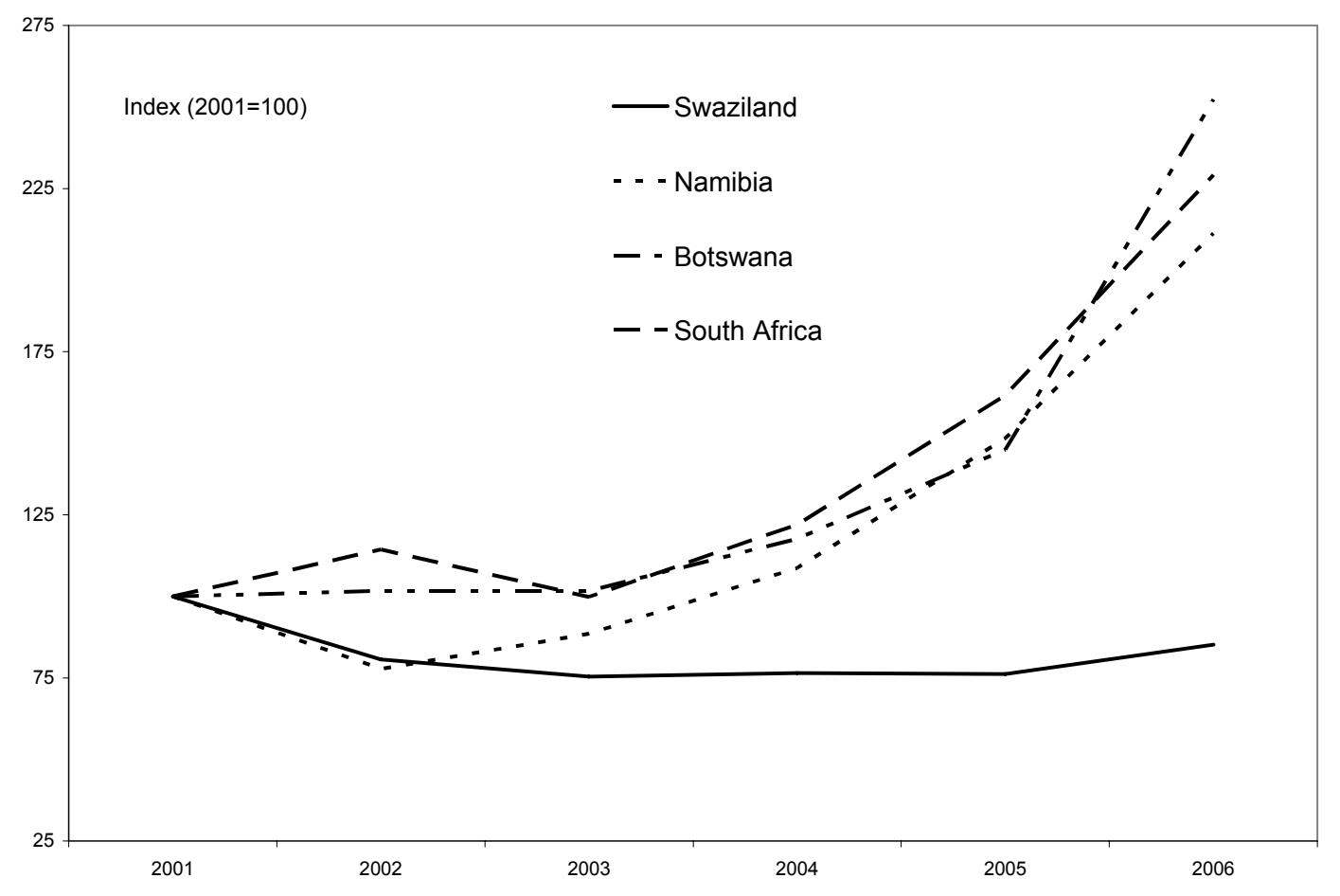




\section{Financial Sector Efficiency and Profitability}

\section{Swaziland's banks do not appear to be as efficient or cost effective as banks in}

Namibia and Botswana. High interest margins and overhead costs generally reflect less efficiency. Based on these criteria, Botswana and Namibia do much better than Swaziland though such cross-country comparisons should be treated with care. ${ }^{7}$ High bank concentration generally leads to less competition, which allows banks to enjoy their market power by earning high interest margins and operating with high overhead costs. In this regard, Swaziland's more concentrated banking system than Namibia, the lowest among the SACU countries, may account for its higher overhead costs and higher net interest margin.

Table II.4. Banking System Efficiency Profitability ${ }^{1}$

\begin{tabular}{|c|c|c|c|c|c|}
\hline & $\begin{array}{l}\text { Net interest margin } \\
\text { (percent of assets) }\end{array}$ & $\begin{array}{l}\text { overhead costs } \\
\text { (percent of assets) }\end{array}$ & $\begin{array}{l}\text { Return on assets } \\
\quad \text { (percent) }\end{array}$ & $\begin{array}{l}\text { Return on equity } \\
\quad \text { (percent) }\end{array}$ & $\begin{array}{l}\text { Bank concentration }{ }^{2} \\
\text { (percent) }\end{array}$ \\
\hline Swaziland & 6.2 & 7.1 & 5.9 & 30.3 & 81.7 \\
\hline Namibia & 5.3 & 3.7 & 1.5 & 19.9 & 77.5 \\
\hline Botswana & 3.6 & 3.9 & 6.1 & 62.3 & 94.4 \\
\hline Lesotho & 3.5 & 12.0 & 2.0 & 27.0 & 100 \\
\hline South Africa & 8.2 & 5.2 & 1.4 & 18.6 & 98.5 \\
\hline Sub-Saharan Africa (mean) & 8.2 & 6.1 & 2.1 & 20.1 & 82.1 \\
\hline Sub-Saharan Africa (median) & 5.9 & 5.5 & $\ldots$ & $\ldots$ & 88.6 \\
\hline Foreign banks in Africa & $\ldots$ & $\ldots$ & 2.8 & 26.7 & $\ldots$ \\
\hline
\end{tabular}

\footnotetext{
Sources: Honohan and Beck (2007); African Department Regional Outlook (May 2006); IMF staff reports; and Beck, Demirgüç-Kunt Levine ( 2007 updated).

${ }^{1}$ Latest available data (2005 or 2006) or averages over 2004-06.

${ }^{2}$ Assets of three largest banks as a share of assets of all commercial banks.
}

\section{Banks in Swaziland are earning more from noninterest income than interest}

income. Although commercial banks in Swaziland compete for customers, their noninterest income (with reportedly high bank charges) has become more important over time, rising from 36 percent of their total income in 2001 to over 45 percent in 2006 . This trend increase raises some concerns about future prospects for lending as it could result in disintermediation from the banking system, slowing down the deepening of domestic financial markets at least through the banking system. In fact, some disintermediation may have already taken place as SCCOs have grown in size significantly.

26. Despite the high overhead costs, banks are profitable with Swaziland's banking system enjoying the second highest level of profitability among SACU countries. This is based on either rate of return on equity or on assets. It is not clear why overhead costs are so different across SACU countries since the three foreign banks that operate in Swaziland are also present in Namibia and Botswana and these countries having similar population sizes.

\footnotetext{
${ }^{7}$ For example, Lesotho's banking system is the most efficient, based on net interest margin, but least efficient based on overhead costs.
} 
Differences in population density and unionization of workers in the banking sector may explain part of the difference, but further work on bank-level analysis may shed more light on the issue.

\section{E. Key Constraints to a Deeper and Healthier Financial System}

27. Delays in enacting several financial bills constrain development of a deeper and healthier financial system. While progress has been made regarding the insurance and pension funds, passage of three important financial laws are still pending; the Securities Bill (1993), aimed at developing the security market; the Financial Services and Regulatory Authority Bill (FSRA 2003), aimed at consolidated supervision and regulation of nonbank financial institutions, including SCCOs, insurance and pension funds; and the National Clearing and Settlement Systems Bill (NCSS, 2004) that has allowed smooth operation of the payment system but has no legal basis, which may subject the central bank and commercial banks to potential lawsuits.

28. The existing regulatory and supervisory agency in charge of the SCCOs, MoAC, faces weak capacity and resource constraints:

- $\quad$ No prudential standards have been established by the regulator;

- $\quad$ Lack of capacity leads to insufficient monitoring and supervision;

- Financial institution expertise is sorely lacking at all levels of the cooperative sector. In particular, the inability to manage credit risk will lead to a continued deterioration of the sector;

- $\quad$ The audited financial statements of credit cooperatives do not meet international audit and accounting standards;

- $\quad$ The capacity, both in terms of manpower and expertise, within the Cooperatives Department to conduct effective off-site and on-site monitoring is extremely limited;

- $\quad$ Given the size of the SCCOs, no credit cooperative in Swaziland has adopted a comprehensive banking computer software system to track its deposits and lending operations;

- $\quad$ The SCCO's Apex organization (SACCO) also faces capacity constraints in enforcing best practices in risk management among its members; and

- $\quad$ Delays in implementing the FSRA bill and unclear laws may have prevented the CBS from assisting with the supervision of the SCCOs. 
29. Surveys of investment climate show a persistent pattern of weaknesses that constrain decisions to invest and access financial markets. According to the World Bank's Doing Business 2008, Swaziland is ranked 175 out of 178 countries in the category called protecting investors, which consists of financial disclosure, Directors' rights, shareholders' rights and investor protection, all of which are essential factors that add depth to financial markets and can safeguard a healthy financial sector. According to the World Bank's Enterprise Survey (2006) the top constraint cited by business firms was anticompetitive or informal practices while access to finance was cited as the fourth most binding constraint. The Doing Business 2008 shows that obtaining credit is easy vis-à-vis the rest of the world as Swaziland is ranked 36 out of 178 countries, but the same survey also shows that once credit is granted, protection of investors' rights is not guaranteed.

30. Restrictions on land ownership limit financial depth as well as efficiency of investment in the real sector. Ownership rights to the Swazi Nation Land, which accounts for 60 percent of the land is severely restricted, thus preventing any individual from using it as a collateral for accessing the financial sector. High poverty, high inequality and a sizable informal sector impose further constraints on financial depth.

31. Low economic growth is a reflection of many factors, but weak growth prospects limits growth of the financial sector and vice versa. Research has shown that higher financial depth is causal to the growth process, at least in a temporal sense, i.e., other things being equal, countries that start with a high initial financial depth have grown faster subsequently. In Swaziland's case, low growth and low financial depth have coexisted for almost ten years now. Although efficiency in use of funds also matters to the growth process, the lack of investment opportunities outside the textile and sugar sectors has also constrained growth.

\section{F. Conclusion}

32. The authorities need to formulate a financial sector strategy that addresses Swaziland's twin challenges of enhancing financial development and ensuring financial stability. Key elements of a forward looking financial sector strategy could include:

- Legislation: Pass the three financial sector laws to improve the investment climate and send a signal to potential investors by enforcing the laws;

- SCCOs: Improve supervision of SCCOs to safeguard their financial viability and allow SCCOs to fulfill their potential in providing financial access to the public at competitive costs. Given the serious limits of financial expertise, considerations should be given to consolidated supervision of all deposit-taking cooperatives to maximize synergy by passing the FRA bill. The monetary survey compiled by the CBS should start including accounts of SCCOs and be extended over time to include other cooperatives; 
- $\quad$ Restrictions on the financial sector: Opt for gradual phasing of the domestic investment requirements for insurance and pension funds; explore Public Private Partnerships as a way of developing viable projects that could be financed by use of the domestic investment requirement; and over time securitization should be an option; expand the availability of long lease arrangements (99 years or more) for the Swazi Nation land and allow these leases to be used as collateral;

- Insurance and pension funds: Continue building up the regulatory capacity of the Registrar of Insurance Companies and Retirement Funds in areas of legislation, supervisory policy and staff development per action plan agreed with the MCM;

- Access to finance: Promote competition and disclosure in the financial sector with an eye toward reducing bank charges and SCCO's informal charges; consider removing restrictions on women's access to finance;

- Growth strategy: Swaziland needs a growth strategy that removes binding constraints on its growth; in many cases removal of these constraints also deepens the financial sector;

- Basel II: Seek technical assistance that enables the staff of the supervision department at the CBS to monitor compliance of the three subsidiaries of South African banks with Basel II, although these banks will continue to prepare their accounts under Basel I as well; and

- Stock market: This is by far the most developmental and challenging component of a future financial sector strategy as it requires progress in many areas of reform outlined above. In time, development of a secondary bond market should also be considered.

33. The above strategy should be sequenced and prioritized. Reforms that safeguard financial stability should be tackled first, thus limiting any possible systemic effects on the financial sector, followed by reforms that increase the depth of Swaziland's financial markets. Some reforms, such as the domestic investment requirement, will be more challenging in the short to medium term than others in deepening financial markets and therefore in need of more urgent attention. 


\section{References}

Beck, Thorsten, Asli Demirgüç-Kunt and Ross Levine, 2007, "Finance, Inequality and the Poor," Journal of Economic Growth, vol. 12, issue 1, pp. 27-49

Demirgüç-Kunt, Ali and Ross Levine, 2001, eds, Financial Structure and Economic Growth. The MIT Press.

Gelbard, Enrique A. and Sergio Pereira Leite, 1999, "Measuring Financial Development in Sub-Saharan Africa," IMF Working Paper 99/105 (Washington D.C: International Monetary Fund)

Honohan, Patrick and Thorsten Beck, 2007, Making Finance Work for Africa. (World Bank: Washington D.C.)

World Bank, 2007, Finance for All? Policies and Pitfalls in Expanding Access. (World Bank: Washington D.C.) 


\section{Responding to The Challenges in the Global Trading Regimes for SWAZILAND's TEXTILES AND SUGAR SECTORS ${ }^{1}$}

\section{A. Introduction}

1. Over the past six years, Swaziland's export sector has performed well, relying increasingly on developments in the textile and sugar sectors. Beginning in 2000 , the textile sector saw rapid growth and a major inflow of foreign direct investment with a consequent increase in employment levels. At the same time, sugar production rose steadily benefiting from heavy investments in irrigation systems and other infrastructure development. Only soft drink concentrate did better than these sectors in terms of foreign exchange earnings, but their combined contribution to the overall economy and employment levels far outstripped that of the soft drink concentrate.

2. Traditionally, Swaziland has received trade preferences from the United States, primarily for apparel exports under the African Growth and Opportunity Act (AGOA), ${ }^{2}$ and from the EU, for sugar exports. ${ }^{3}$ Under these agreements, both apparel and sugar exports flourished. Between 2000 and 2005, apparel exports jumped more than 258 percent while sugar exports grew steadily by more than 50 percent over the same period.

3. However, exports of these commodities, which accounted for 31.2 percent of total exports in $\mathbf{2 0 0 6}$ are seriously threatened by changes in the global trade regime and trade liberalization. These developments has seen the removal of trade preferences for textiles (Multi Fiber Agreement (MFA) in December 2004), and the phasing out of the preferential prices for sugar to the EU market. In July 2004, the EU announced a phased reduction, over four years, of prices for sugar imports by 36 percent.

\section{Since the changes, exports of both textiles and sugar have been adversely}

affected. In 2006, textile exports fell by 9 percent over the 2005 level the first time in five years, and that despite the extension of AGOA to 2015. Sugar exports also failed to register their usual strong growth as the industry began to grapple with the drop in the EU preferential prices.

\footnotetext{
${ }^{1}$ Prepared by Thomson Fontaine.

2 The African Growth and Opportunity Act (AGOA) were signed into law on May 18, 2000 as Title 1 of The Trade and Development Act of 2000. The Act offers tangible incentives for African countries to continue their efforts to open their economies and build free markets. President Bush signed amendments to AGOA, also known as AGOA II, into law on August 6, 2002 as Sec. 3108 of the Trade Act of 2002. AGOA II substantially expands preferential access for imports from beneficiary Sub-Saharan African countries.

${ }^{3}$ The EU sugar protocol with several African Caribbean and Pacific (ACP) countries was first signed in 1975.
} 
5. A further challenge complicating these most recent developments is Swaziland's membership in the Southern African Customs Union (SACU) and the Southern African Development Community (SADC), which largely determines that country's external trade policy. In addition, Swaziland is seeking to reconcile its participation in the Common Market for Eastern and Southern Africa (COMESA) free trade area with its SACU membership. It is unclear for instance how a SACU-US free trade area currently under negotiation would impact apparel exports since other SACU-member countries also produce apparel. The same goes for efforts at attainment of a full SADC FTA by 2008.

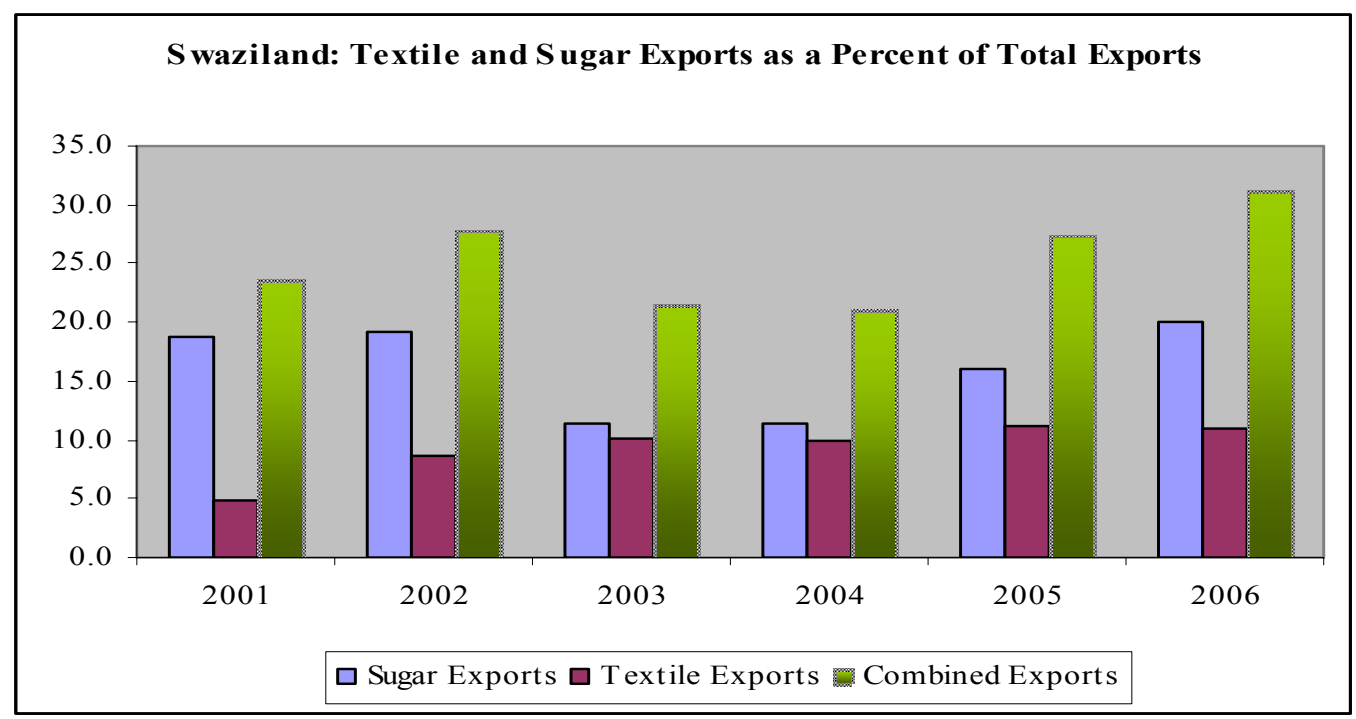

Source: Central Bank of Swaziland and IMF staff estimates

6. The rest of the paper is organized as follows: the challenges currently facing the textile and sugar sectors are defined, followed by efforts currently underway to respond to those challenges, and concludes with a look at the way forward for that country.

\section{B. Defining the Challenges}

7. With two of Swaziland's three main exports under threat, the country will have to find ways to address this challenge. Compounding the threat to exports of sugar and textiles is the looming issue of remaining competitive in a quickly changing global environment. The situation is made worse by issues of governance, the high cost of doing business, falling labor productivity and the impact of the HIV/AIDS epidemic.

\section{The textile sector in Swaziland}

8. Under the MFA, which came into force at the start of 1974, countries were allowed to negotiate bilateral treaties that permitted them to tailor quantitative restrictions on imports differentially according to their own particular requirements. The United States and European countries moved to impose quota restrictions on all countries in order to protect their own industries. A review of the MFA in 1986 removed 
provisions that could have provided the basis for a further tightening of existing quotas. Finally, in 1991, the Agreement on Textiles and Clothing (ATC) was negotiated as part of GATT's Uruguay Round of trade negotiations, and a final version negotiated in 1995 allowed for the structured removal of global quotas on textiles and clothing.

9. Despite the introduction of the ATC, in the late 1990's, sub-Saharan African countries including Swaziland were particularly favored for investments in textiles because of unfilled quotas under the MFA. As such, Swaziland attracted large investments in the textile sector, mainly from Asia and South Africa. The country's position was also helped by the fact that its exchange rate was favorable with that of the US dollar; there was duty free access to the United States under the AGOA, and a relatively stable political environment. Manufacturers were able to import fabric from Asia under the third country fabric provision of AGOA to be used in the manufacturing of garments exported to the United States.

\section{Consequently, between 1998 and 2005 textile exports from Swaziland jumped} from US \$15.2 million to US \$181.0 million, and in 2006 represented 11 percent of total exports, most of it going to the US. Also, more than 30,000 workers found employment in newly opened factories-about one quarter of formal sector jobs.

\section{The phasing out of the MFA quotas on January 1, 2005 under the ATC,} combined with significant currency appreciation had a damaging impact on the textile sector of Swaziland. No longer constrained by quotas, several Asian companies left to return to their countries of origin. ${ }^{4}$ The impact on employment was particularly severe as employment levels dropped by two-thirds to below 10,000, with a subsequent drop in exports.

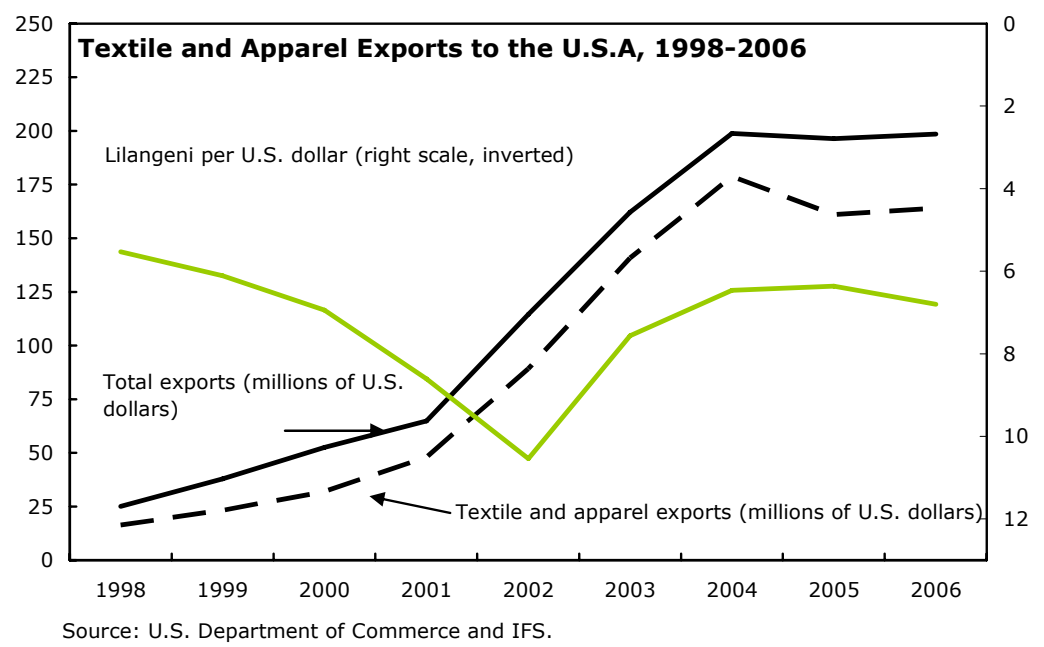

\footnotetext{
${ }^{4}$ The United States and the European Union subsequently negotiated new, temporary quota arrangements with China.
} 


\section{The continuing appreciation of the South African rand (to which Swaziland's}

currency is pegged 1:1) against the US dollar poses another obstacle to the growth and expansion of the textile sector. Between 2000 and 2002 when most of the companies set up shop in that country, the exchange rate was hugely advantageous. Since then it has appreciated from a level in 2003 of R12 to $\$ 1$ to its current level of about R7.2 to \$1. Indeed, such a currency appreciation could not have come at a worse time even as the battle continues to save the textile sector following the expiration of the MFA.

\section{There are other challenges currently facing the apparel sector including high} utility and transport costs, and strong and consistent wage demands. These factors all negatively impact the textile sector. Wages in the garment sector are already considered high compared to neighboring countries with the exception of South Africa. Beyond 2012, it is expected that there will be increased competition from other Asian countries including China, India, Bangladesh and Vietnam, countries known to produce textiles at lower costs than Swaziland. Additionally, the rising incidence of HIV/AIDS adversely impacts productivity. Discussions are ongoing on ways to better position the sector to deal with these mounting challenges.

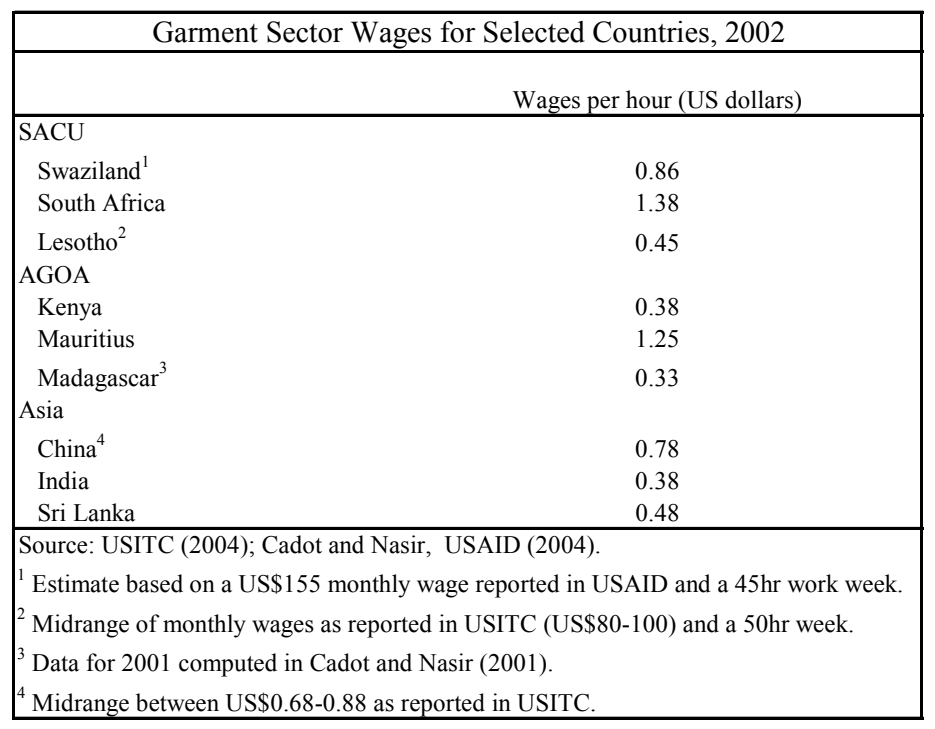




\section{The sugar sector in Swaziland}

14. Swaziland has invested heavily in the sugar sector. Sugar cane is harvested both on Swazi Nation Land (SNL) and Title Deed Land (TDL). SNL accounts for 60 percent of land area and one fourth of agricultural production and is held in trust by the king and allocated by tribal chiefs according to traditional arrangements. The land is rain-fed and is mainly used for subsistence farming. On the other hand, TDL, which accounts for most of the commercial sugar production, is held by freehold tenure, has exclusive access rights, and is well irrigated. The Maguga dam project was completed in 2006/07, which allowed for the irrigation of over 6,000 hectares of sugar and benefited well over 30,000 households. The Lower Usuthu Smallholder Irrigation Project (LUSIP) is expected to become operational in September 2008, further impacting sugar production.

Swaziland: Sugar Cultivation Production and Exports

\begin{tabular}{|lcccccc|}
\hline & $2001 / 02$ & $2002 / 03$ & $2003 / 04$ & $2004 / 05$ & $2005 / 06$ & $2006 / 2007$ \\
\hline & & & & & & \\
Area under cultivation (hectares) & 47,256 & 48,307 & 49,932 & 50,932 & 52,196 & 52,233 \\
Production (tonnes) & 500,680 & 583,014 & 628,191 & 597,563 & 652,735 & 623,357 \\
Exports (US \$ million) & 196.5 & 197.5 & 157.9 & 204.4 & 259.4 & 298.6 \\
EU & 71.8 & 85.0 & 56.7 & 76.1 & 86.7 & 93.2 \\
SACU & 101.1 & 86.4 & 83.1 & 105.9 & 130.5 & 144.4 \\
Other & 23.6 & 26.2 & 18.2 & 22.3 & 42.2 & 61.0 \\
\hline
\end{tabular}

Source: Central Bank of Swaziland and IMF staff estimates

15. Sugar production has greatly benefited Swaziland. With access to the EU and regional sugar markets, export earnings increased by over 50 percent in just five years. Infrastructural works including the two large irrigation projects have provided a much needed boon to the economy and allowed several thousand farmers to actively engage in sugar production. Vibrant communities have arisen around the sugar plantations with the Swaziland Sugar Association providing social and health services to households. Sugar also contributes as much as 8 percent on average to GDP.

\section{Traditionally, the sugar regime in} the EU have accounted for three-fourths of Swaziland's sugar exports (excluding SACU exports), with the exception of 2006/07 when it fell to about 60 percent. Under the African, Caribbean, and Pacific (ACP) Trade Protocol agreement, the EU purchases and imports specific quantities of cane sugar that originates in the ACP states

\begin{tabular}{|c|c|c|}
\hline \multicolumn{3}{|c|}{ Changes in prices for ACP Sugar Protocol } \\
\hline Year & Price per & $\%$ change \\
\hline & tonne & (cummulative) \\
\hline Previous regime & $€ 523.70$ & 0 \\
\hline $2006 / 07$ & $€ 496.80$ & -5.1 \\
\hline $2007 / 08$ & $€ 496.80$ & -5.1 \\
\hline $2008 / 09$ & $€ 434.10$ & -17.1 \\
\hline $2009 / 10$ & $€ 335.00$ & -36.0 \\
\hline
\end{tabular}
at guaranteed prices that are well above market prices. Under this arrangement, Swaziland 
benefited greatly from selling its sugar to the EU at above the world market price. However, in July 2004, the EU announced a phased reduction in the price paid for sugar imports and in September 2007 formally denounced the agreement. After the 5.1 percent reduction in 2007/08, the price will fall a further 12.0 percent in 2008/09, and a final price cut of 19 percent will be effected in 2009/10.

\section{Already, Swaziland is feeling the effect of the price cut under the ACP Trade}

Protocol Agreement. During 2007, several small (subsistence) farmers faced with falling yields due to a drought and escalating costs were unable to meet their loan obligations as the price fell. A few lending agencies also refused to extend further credit to these farmers. In 2006/07 sugar production dropped by 4.5 percent and overall sugar exports dipped by just under 1 percent. With the anticipated 12 percent drop in EU prices in 2008/09 it is expected that export earnings will decline further and that there will be a continuing adverse impact on employment, the economy and on agriculture production in Swaziland. The EU's granting of monitored duty free-quota free access under its new global trading regime is sure to increase competition on that market amongst sugar suppliers. A situation, which will only intensify after the granting of full duty free-quota free access beyond 2015.

\section{Questions however persist as to whether Swaziland's sugar industry will be able} to compete at world market prices. The reality of increased competition from lower cost producers like Brazil and Thailand, partially during the transition, and fully from October 2015 will pose a serious challenge to the continued viability of Swaziland's sugar industry. While the country will enjoy unlimited access to the EU market beyond 2015, it does not mean that it will be able to export unlimited quantities. It therefore remains to be seen whether the sector can be competitive while receiving much lower prices than traditionally paid. A recent European Research Office note on the ACP sugar trade with the EU highlights that by 2015 the price offered for ACP/LDC sugar on the EU market could fall to $€ 261.85$ per ton, a further 22 percent drop in price from the anticipated 2009/10 level.

\section{Declining competitiveness}

19. Swaziland continues to face the daunting challenge of remaining competitive in a rapidly changing global environment. Linked to this competitiveness challenge is the ability to attract and sustain foreign direct investment. In particular, new investment flows into the ailing textile industry is sorely needed. Swaziland is however saddled by the high cost of doing business, and the continuing drop in worker productivity linked to the high incidence of HIV/AIDS. The recent depreciation of the rand has resulted in a moderate depreciation of the lilangeni in real effective terms. The inability to contain rising inflation (for example, by controlling wage and fiscal pressures), could very well further erode competitiveness vis-à-vis South Africa and other trading partners. ${ }^{5}$ As such, competitiveness-

\footnotetext{
${ }^{5}$ An overwhelming majority of Swaziland's trade flows are accounted for by South Africa, which therefore plays a crucial role in determining the real effective exchange rate.
} 
enhancing reforms to increase productivity, reduce the cost of doing business, and improve governance are needed to complement macro-policies. Indeed, the survival of the critical textile and sugar sectors rests on the country's ability to adequately address this issue and reverse the downward trend in competitiveness.

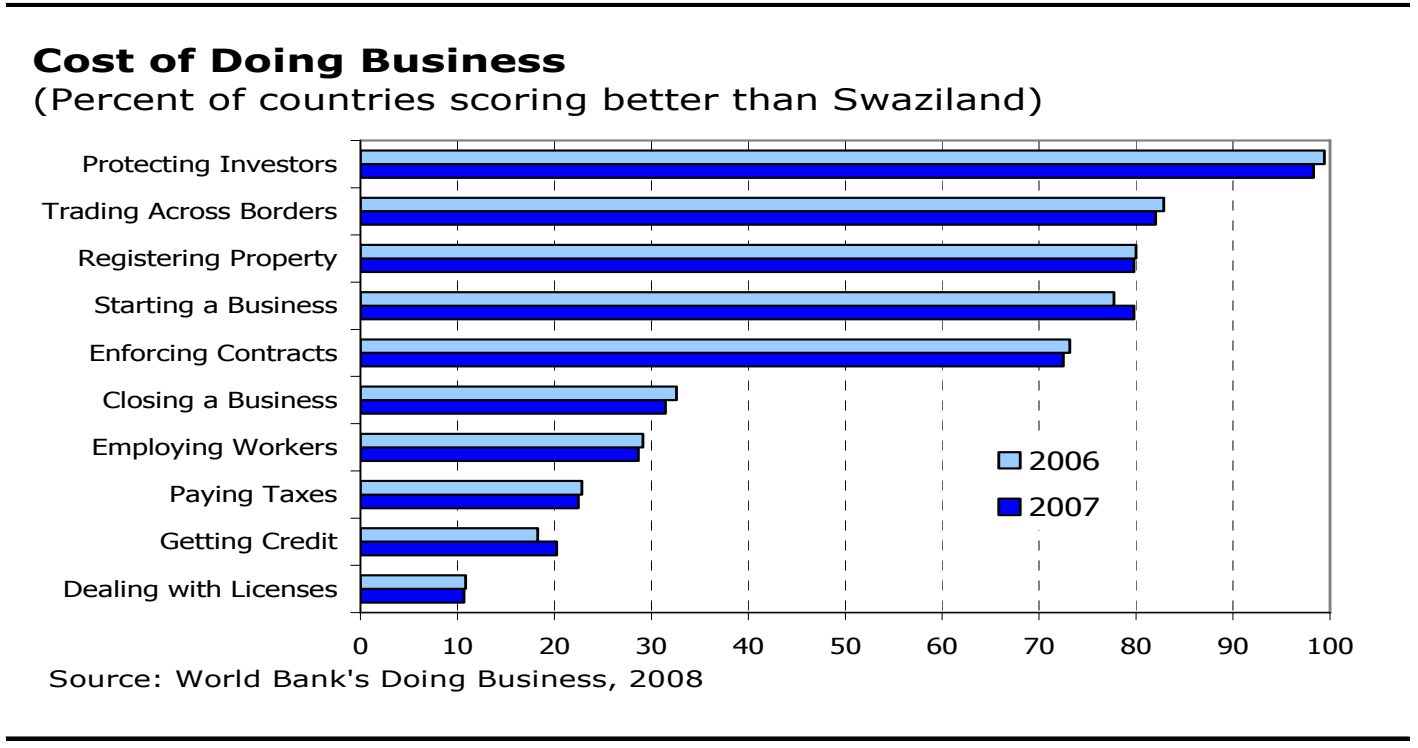

\section{Responding to the Challenges}

\section{Diversification and new opportunities}

20. In the face of the mounting pressure on the textile sector, the focus have been on restoring exports, attracting new investments and seeking to promote organic cotton. Stringent efforts are currently underway by the Swazi authorities to revitalize what's left of the ailing textile sector by attempting to attract new investment and increase the local production of organic cotton. There is a belief in Swaziland that organic cotton provides a niche market. An ongoing organic cotton project is focused on growing cotton on lands currently unsuited for sugar production. The plan is to cultivate up to 4,000 hectares in the South of the country. This would satisfy the AGOA requirement for sourcing materials from Africa, and would also complete a full vertical integration of that sector. ${ }^{6}$ Further opportunities were provided to the sector when the US government agreed to extend duty free access under AGOA to 2015 instead of allowing access to expire as previously agreed in September 2007. Swaziland can however only benefit from sourcing fabric from third countries through 2012.

\footnotetext{
${ }^{6}$ Success in this project would serve to revive a particularly disadvantageous section of Swaziland and contribute much in the fight against rural poverty.
} 
21. Greater efforts must be pursued in diversifying Swaziland's economy. Already, the tourism sector holds out potential in helping drive foreign exchange earnings and in generating significant employment. However, for this potential to be realized, there is need for greater efforts at promoting the country overseas, improving the tourism infrastructure and committing more resources in that regard. Other opportunities such as crop diversification, the development of agribusinesses, and small business development should be pursued.

\section{A recently initialed Economic Partnership Agreement (EPA) between SADC and} the EU may provide continued market access following the denunciation of the ACP Trade Protocol agreement. The EPA agreement that was formally adopted by the EU in December, 2007 agreed for market access regulation that granted duty and quota free access to the EU market from 1 January 2008, with transition periods for sugar and rice. ${ }^{7}$ For sugar a three phased transitional arrangement is envisaged:

- $\quad$ Phase 1 (January 2008-October 2009): a continuation of the sugar protocol, with a substantial improvement of LDC market access for marketing year 2008/09; initial market access for ACP non-LDCs not party to the Sugar Protocol and additional market access for ACP non-LDCs party to the sugar protocol;

- $\quad$ Phase 2 (October 2009-October 2015): duty free and quota free access subject to safeguard arrangements; and

- $\quad$ Phase 3 (October 2015 onwards) full duty free and quota free access to the EU market will be granted.

\section{Seeking alternative trading arrangements}

23. Without a guaranteed and protected EU market access, efforts have shifted to expanding trade within regional markets. While these markets are not as lucrative as the EU market, Swaziland's ability to compete effectively on cost could go a long way in mitigating the negative impact of the loss of EU preferences. Already, the SACU market accounts for nearly 50 percent of sugar exports with $\mathrm{COMESA}^{8}$ and the rest of the world market accounting for a further 25 percent, and there are opportunities for expansion. Currently, there is a concerted effort underway to further reduce production costs and to

\footnotetext{
${ }^{7}$ In addition to Swaziland, other SADC countries that initialed the agreement were Botswana, Lesotho, Mozambique and Namibia.

${ }^{8}$ Swaziland recently benefited from a one year derogation with COMESA, which allowed increased trade, but it is not clear if this will again be granted by SACU. In the meantime, COMESA is moving to a customs union during 2008.
} 
move Swaziland from the third least cost producer of sugar in the world to a more advantageous position. ${ }^{9}$

\section{Several ongoing negotiations for various trade deals with different trading} blocks and countries also holds out the prospects for increasing sugar, textiles and other exports. Among these:

- Negotiations have concluded on a SACU-EFTA (European Free Trade Association) free trade agreement, ${ }^{10}$ and await implementation after ratification by all parties-The agreement aims to achieve substantial liberalization of trade in both agricultural and nonagricultural goods, in conformity with the GATT. For Swaziland it is expected to increase market access into the European countries of Switzerland, Norway, Liechtenstein, and Iceland;

- $\quad$ SACU is negotiating with the US on a Trade and Investment Cooperation Agreement (TICA) with a view to implementation by early 2008. This is largely viewed as a prelude to a FTA agreement with the US;

- $\quad$ SACU is negotiating a preferential Trade Agreement with the Latin American trading block MERCOSUR. ${ }^{11}$ It is anticipated that the first phase of the agreement would entail a fixed preferential tariff agreement to allow some goods easy access to each other's markets. The second phase would entail a full Free Trade Area;

- India recently indicated an interest in signing an FTA with SACU, and studies into the impact of a trade arrangement with China are still continuing;

- Negotiations are currently underway to broaden SACU to include other SADC members; and

- Negotiations at the technical level continue on the SADC FTA by 2008 and Customs Union by 2010. It is not certain whether the target dates would be met.

\section{Efforts at improving competitiveness}

25. Reducing the high cost of doing business, land and labor productivity, attracting FDI, and creating an enabling environment for private sector-led growth are all critical in improving Swaziland's competitiveness. Key elements should include skills-training

\footnotetext{
${ }^{9}$ Swaziland is considered to be behind Brazil and Australia in terms of cost per ton of producing sugar.

${ }^{10}$ The negotiations were started in May 2003 and concluded in November 2007.

${ }^{11}$ The Common Market of the South (MERCOSUR) is composed of member states Brazil, Argentina, Uruguay, and Paraguay, and associate states Bolivia, Chile, Colombia, Ecuador, and Peru.
} 
combined with policies to alleviate the productivity-eroding impact of skill mismatches, labor market rigidities, and HIV/AIDS. To attract investment there should be a focus on: (i) simplifying business licensing requirements and procedures; (ii) improving transportation, energy, and telecommunication infrastructures; and (iii) increasing land productivity, partly by a land reform strategy.

26. Ongoing efforts by the authorities to help improve competitiveness will help in preparing the country for the challenges ahead. The parliamentary passage of an anticorruption bill and the establishment of a Business Economic Advisory Panel to help improve the country's image are useful first steps. Also, The Swaziland Investor Roadmap 2005 prepared by the USAID and the World Bank's Investment Climate Assessment Survey has highlighted the complications caused by government regulations and identified concrete steps to improving the investment climate. Implementation of the recommendations contained in both studies will go a long way in helping Swaziland survive in this changing environment.

\section{Conclusion}

\section{Recent changes in the global trading regimes have forced Swaziland to reassess} its external position. The continuing momentum by various trading blocks towards full trade liberalization means that this country can no longer rely on having protected access to foreign markets. As such, in this new environment, the emphasis is on tackling productivity issues, improving competitiveness, and working to secure mutually beneficial trading arrangements with various countries and trade blocks.

28. The success or failure of this strategy will have far reaching implications for the Swazi economy, employment and the fight against poverty reduction. Sugar cultivation has served the country well in attempting to tackle rural poverty. The survival of this sector is therefore critical in helping win the fight against poverty. Efforts at expanding cotton production within Swaziland are also key in helping against that fight. Ultimately, the country has too much to lose to not at lest work vigorously to mitigate the impact of a changing global environment. 


\section{References}

Cadot O. and Nasir J. (2001) Incentives and Obstacles to Growth: Lessons from Manufacturing Case Studies in Madagascar. Washington DC World Bank Regional Program on Enterprise Development Discussion Paper no. 17.

Central Bank of Swaziland, April 2006-March 2007, Annual Report, (Mbabane).

European Research Office, July 2007, “ The ACP Sugar Trade with the EU,” (Brussels).

Fontaine, Thomson, July 2007, "End of Quotas Hits African Textiles,” in IMF Survey.

Naumann, Eckart, April 2006, “The Multifibre Agreement-WTO Agreement on Textiles and Clothing,” Tralac Working Paper, No 4/2006. 
Statistical APPEndix TABles

Table 1. Swaziland: Gross Domestic Product by Sector of Origin at 2000 Constant Prices, 2001-06

\begin{tabular}{|c|c|c|c|c|c|c|}
\hline & 2001 & 2002 & 2003 & 2004 & 2005 & 2006 \\
\hline & \multicolumn{6}{|c|}{ (In millions of emalangeni) } \\
\hline Primary production & 977.0 & $1,031.5$ & $1,074.6$ & $1,044.4$ & $1,093.8$ & $1,071.6$ \\
\hline Agriculture and livestock & 894.8 & 945.3 & 993.2 & 956.4 & $1,009.3$ & 986.9 \\
\hline SNL crops ${ }^{1}$ & 72.9 & 57.8 & 55.0 & 64.3 & 64.1 & 54.8 \\
\hline $\mathrm{TDL}_{\text {crops }^{2}}$ & 747.6 & 803.8 & 855.0 & 828.2 & 867.6 & 853.3 \\
\hline Livestock and other & 74.3 & 83.7 & 83.2 & 63.9 & 77.7 & 78.8 \\
\hline Forestry & 54.5 & 55.4 & 56.8 & 61.2 & 63.4 & 60.4 \\
\hline Mining & 27.7 & 30.8 & 24.6 & 26.8 & 21.1 & 24.4 \\
\hline Secondary production & $2,809.8$ & $2,841.6$ & $2,979.8$ & $2,993.5$ & $2,975.3$ & $3,042.6$ \\
\hline Manufacturing & $2,422.8$ & $2,474.9$ & $2,519.6$ & $2,544.8$ & $2,567.7$ & $2,619.1$ \\
\hline Electricity and water & 96.1 & 109.8 & 112.3 & 109.6 & 113.7 & 119.5 \\
\hline Construction & 290.9 & 256.9 & 347.8 & 339.1 & 293.8 & 304.1 \\
\hline Services & $3,314.8$ & $3,405.0$ & $3,495.1$ & $3,714.8$ & $3,881.5$ & $4,060.3$ \\
\hline Wholesale and retail & 457.9 & 419.8 & 414.2 & 456.2 & 492.3 & 547.4 \\
\hline Hotels and restaurants & 115.9 & 120.8 & 124.5 & 128.7 & 140.6 & 151.8 \\
\hline Transport & 216.7 & 223.0 & 252.9 & 267.1 & 278.3 & 265.7 \\
\hline Communications & 324.2 & 394.1 & 395.2 & 493.6 & 561.4 & 589.8 \\
\hline Banking, finance, and insurance & 265.8 & 297.0 & 317.5 & 328.2 & 337.8 & 352.2 \\
\hline Real estate & 288.9 & 299.4 & 310.5 & 318.8 & 326.2 & 336.4 \\
\hline Government services & $1,503.0$ & $1,520.4$ & $1,563.6$ & $1,614.6$ & $1,636.9$ & $1,712.1$ \\
\hline Other services & 114.0 & 116.3 & 118.6 & 121.0 & 123.8 & 126.8 \\
\hline Owner-occupied dwellings & 207.9 & 214.8 & 212.6 & 208.4 & 212.4 & 216.2 \\
\hline Imputed bank service charge & -179.6 & -200.7 & -214.5 & -221.7 & -228.3 & -238.0 \\
\hline GDP at factor cost & $7,101.6$ & $7,278.1$ & $7,549.5$ & $7,752.7$ & $7,950.5$ & $8,174.6$ \\
\hline Indirect taxes less subsidies & $1,847.0$ & $1,863.0$ & $1,935.3$ & $1,976.8$ & $2,008.1$ & $2,065.6$ \\
\hline \multirow[t]{2}{*}{ GDP at market prices ${ }^{3}$} & $8,948.6$ & $9,141.1$ & $9,484.8$ & $9,729.4$ & $9,958.7$ & $10,240.2$ \\
\hline & \multicolumn{6}{|c|}{ (Annual percentage change) } \\
\hline Agriculture and livestock & -9.2 & 5.6 & 5.1 & -3.7 & 5.5 & -2.2 \\
\hline Forestry & 2.8 & 1.6 & 2.7 & 7.8 & 3.5 & -4.8 \\
\hline Mining & -19.9 & 11.2 & -20.1 & 9.0 & -21.5 & 15.8 \\
\hline Manufacturing & 0.9 & 2.1 & 1.8 & 1.0 & 0.9 & 2.0 \\
\hline Electricity and water & 5.4 & 14.2 & 2.3 & -2.5 & 3.8 & 5.1 \\
\hline Construction & 19.5 & -11.7 & 35.4 & -2.5 & -13.3 & 3.5 \\
\hline Services & 2.6 & 2.7 & 2.6 & 6.3 & 4.5 & 4.6 \\
\hline \multirow[t]{2}{*}{ GDP at market prices } & 0.9 & 2.2 & 3.8 & 2.6 & 2.4 & 2.8 \\
\hline & \multicolumn{6}{|c|}{ (In percent of GDP at factor cost) } \\
\hline Agriculture and livestock & 12.6 & 13.0 & 13.2 & 12.3 & 12.7 & 12.1 \\
\hline Forestry & 0.8 & 0.8 & 0.8 & 0.8 & 0.8 & 0.7 \\
\hline Mining & 0.4 & 0.4 & 0.3 & 0.3 & 0.3 & 0.3 \\
\hline Manufacturing & 34.1 & 34.0 & 33.4 & 32.8 & 32.3 & 32.0 \\
\hline Electricity and water & 1.4 & 1.5 & 1.5 & 1.4 & 1.4 & 1.5 \\
\hline Construction & 4.1 & 3.5 & 4.6 & 4.4 & 3.7 & 3.7 \\
\hline Services & 46.7 & 46.8 & 46.3 & 47.9 & 48.8 & 49.7 \\
\hline
\end{tabular}

Source: Central Statistical Office.

${ }^{1}$ Swazi Nation Land (SNL).

${ }^{2}$ Title Deed Land (TDL).

${ }^{3}$ Under review by the CSO; data on indirect taxes used for estimation of GDP may contain errors and are subject to downward revisions based on the review. 
Table 2. Swaziland: Gross Domestic Product by Sector of Origin at Current Prices, 2001-06 (In millions of emalangeni, unless otherwise indicated)

\begin{tabular}{|c|c|c|c|c|c|c|}
\hline & 2001 & 2002 & 2003 & 2004 & 2005 & 2006 \\
\hline Primary production & $1,035.5$ & $1,144.9$ & $1,123.9$ & $1,140.7$ & $1,183.3$ & $1,208.2$ \\
\hline Agriculture and livestock & 922.8 & $1,018.4$ & 993.1 & 997.2 & $1,038.7$ & $1,041.2$ \\
\hline SNL crops ${ }^{1}$ & 92.1 & 70.8 & 74.1 & 101.6 & 102.3 & 87.8 \\
\hline TDL $_{\text {crops }}{ }^{2}$ & 752.0 & 859.1 & 838.6 & 813.5 & 859.0 & 865.4 \\
\hline Livestock and other & 78.7 & 88.5 & 80.4 & 82.1 & 77.4 & 88.0 \\
\hline Forestry & 78.1 & 79.2 & 80.4 & 86.5 & 100.4 & 110.5 \\
\hline Mining & 34.6 & 47.3 & 50.4 & 57.0 & 44.2 & 56.6 \\
\hline Secondary production & $4,308.6$ & $4,712.7$ & $5,325.1$ & $5,600.6$ & $5,742.3$ & $6,525.3$ \\
\hline Manufacturing & $3,794.1$ & $4,176.6$ & $4,577.6$ & $4,820.2$ & $5,042.0$ & $5,798.3$ \\
\hline Electricity and water & 81.2 & 101.4 & 108.0 & 124.6 & 132.1 & 138.9 \\
\hline Construction & 433.3 & 434.7 & 639.6 & 655.8 & 568.3 & 588.2 \\
\hline Services & $3,983.1$ & $4,447.5$ & $4,851.2$ & $5,389.7$ & $5,875.1$ & $6,453.3$ \\
\hline Wholesale and retail & 626.5 & 656.4 & 669.2 & 813.5 & 919.8 & $1,048.6$ \\
\hline Hotels and restaurants & 175.8 & 200.5 & 205.5 & 206.9 & 211.4 & 264.2 \\
\hline Transport & 312.5 & 348.2 & 374.8 & 396.8 & 424.1 & 395.9 \\
\hline Communications & 341.8 & 469.8 & 532.6 & 607.6 & 662.7 & 736.0 \\
\hline Banking, finance, and insurance & 242.3 & 285.1 & 314.2 & 382.4 & 443.6 & 491.6 \\
\hline Real estate & 430.9 & 480.2 & 523.9 & 559.3 & 597.6 & 637.3 \\
\hline Government services & $1,614.9$ & $1,783.3$ & $2,003.0$ & $2,222.5$ & $2,434.3$ & $2,711.8$ \\
\hline Other services & 171.2 & 195.5 & 214.9 & 226.5 & 242.0 & 251.4 \\
\hline Owner-occupied dwellings & 230.9 & 221.2 & 225.4 & 232.7 & 239.4 & 248.6 \\
\hline Imputed bank service charge & -163.7 & -192.6 & -212.3 & -258.4 & -299.7 & -332.1 \\
\hline GDP at factor cost & $9,327.2$ & $10,305.1$ & $11,300.2$ & $12,131.1$ & $12,800.7$ & $14,186.8$ \\
\hline Indirect taxes less subsidies & $2,007.1$ & $2,213.8$ & $2,474.4$ & $3,222.3$ & $3,816.0$ & $4,667.2$ \\
\hline GDP at market prices ${ }^{3}$ & $11,334.3$ & $12,518.9$ & $13,774.6$ & $15,353.4$ & $16,616.6$ & $18,854.1$ \\
\hline \multicolumn{7}{|l|}{ Memorandum items: } \\
\hline GDP deflator (index, $2000=100$ ) & 126.7 & 137.0 & 145.2 & 157.8 & 166.9 & 184.1 \\
\hline (percent change) & 6.9 & 8.1 & 6.0 & 8.7 & 5.7 & 10.3 \\
\hline
\end{tabular}

Source: Central Statistical Office.

${ }^{1}$ Swazi Nation Land (SNL).

${ }^{2}$ Title Deed Land (TDL).

${ }^{3}$ Under review by the CSO; data on indirect taxes used for estimation of GDP may contain errors and are subject to downward revisions based on the review. 
Table 3. Swaziland: Gross Domestic Product by Expenditure Category at Current Prices, 2001-06

\begin{tabular}{|c|c|c|c|c|c|c|}
\hline & 2001 & 2002 & 2003 & 2004 & 2005 & 2006 \\
\hline & \multicolumn{6}{|c|}{ (In millions of emalangeni) } \\
\hline Final consumption expenditure & $11,003.3$ & $10,065.9$ & $10,903.5$ & $12,919.1$ & $15,114.3$ & $15,081.0$ \\
\hline Private & $9,080.7$ & $7,731.2$ & $8,222.4$ & $9,496.4$ & $11,665.3$ & $11,397.0$ \\
\hline Government & $1,922.6$ & $2,334.7$ & $2,681.0$ & $3,422.6$ & $3,449.1$ & $3,683.9$ \\
\hline Capital formation & $1,996.4$ & $2,486.4$ & $2,590.4$ & $2,831.6$ & $2,983.3$ & $2,987.4$ \\
\hline Gross fixed capital formation & $1,996.4$ & $2,486.4$ & $2,590.4$ & $2,831.6$ & $2,983.3$ & $2,986.4$ \\
\hline Public & $1,129.3$ & $1,550.9$ & $1,772.6$ & $1,572.6$ & $1,573.6$ & $1,574.6$ \\
\hline Private & 867.1 & 935.5 & 817.8 & $1,259.0$ & $1,409.7$ & $1,411.8$ \\
\hline Increases in stocks & 0.0 & 0.0 & 0.0 & 0.0 & 0.0 & 1.0 \\
\hline Balance of trade for goods and nonfactor serv & $-1,665.4$ & -33.4 & 280.8 & -397.3 & $-1,481.0$ & $-1,451.7$ \\
\hline Exports & $9,954.1$ & $11,923.0$ & $11,953.9$ & $13,279.8$ & $12,062.8$ & $12,009.8$ \\
\hline Imports, f.o.b. ${ }^{1}$ & $-11,619.5$ & $-11,956.4$ & $-11,673.1$ & $-13,677.1$ & $-13,543.8$ & $-13,461.5$ \\
\hline \multirow[t]{2}{*}{ GDP at market prices ${ }^{2}$} & $11,334.3$ & $12,518.9$ & $13,774.6$ & $15,353.4$ & $16,616.6$ & $16,616.6$ \\
\hline & \multicolumn{6}{|c|}{ (In percent of GDP) } \\
\hline Final consumption expenditure & 97.1 & 80.4 & 79.2 & 84.1 & 91.0 & 90.8 \\
\hline Private & 80.1 & 61.8 & 59.7 & 61.9 & 70.2 & 68.6 \\
\hline Government & 17.0 & 18.6 & 19.5 & 22.3 & 20.8 & 22.2 \\
\hline Capital formation & 17.6 & 19.9 & 18.8 & 18.4 & 18.0 & 18.0 \\
\hline Gross fixed capital formation & 17.6 & 19.9 & 18.8 & 18.4 & 18.0 & 18.0 \\
\hline Public & 10.0 & 12.4 & 12.9 & 10.2 & 9.5 & 9.5 \\
\hline Private & 7.7 & 7.5 & 5.9 & 8.2 & 8.5 & 8.5 \\
\hline Increases in stocks & 0.0 & 0.0 & 0.0 & 0.0 & 0.0 & 0.0 \\
\hline Balance of trade for goods and nonfactor serv & -14.7 & -0.3 & 2.0 & -2.6 & -8.9 & -8.7 \\
\hline Exports of goods and services & 87.8 & 95.2 & 86.8 & 86.5 & 72.6 & 72.3 \\
\hline Imports of goods and services, f.o.b. & -102.5 & -95.5 & -84.7 & -89.1 & -81.5 & -81.0 \\
\hline GDP at market prices & 100.0 & 100.0 & 100.0 & 100.0 & 100.0 & 100.0 \\
\hline
\end{tabular}

Source: Central Statistical Office.

${ }^{1}$ All Southern African Customs Union receipts are treated as indirect taxes (and therefore deducted from imports, c.i.f. to get imports, f.o.b.), accounting for the significant difference between the trade figures in the national income accounts reported in this table and those in the balance of payments.

${ }^{2}$ Under review by the CSO; data on indirect taxes used for estimation of GDP may contain errors and are subject to downward revisions based on the review. 
Table 4. Swaziland: Population and Labor Force Estimates, 2001-06

\begin{tabular}{|c|c|c|c|c|c|}
\hline & 2002 & 2003 & 2004 & 2005 & 2006 \\
\hline Annual population growth ${ }^{1}$ & 2.5 & 2.4 & 2.17727 & 1.95889 & 1.74901 \\
\hline Population (in thousands) ${ }^{1}$ & $1,056.0$ & $1,081.2$ & 1104.71 & 1126.35 & 1146.05 \\
\hline Population density (per sq.km.) & 63.3 & 64.3 & 65.1 & 65.8 & 65.5 \\
\hline Labor force $^{2}$ & 314.9 & 319.1 & 322.3 & 331.8 & 337.2 \\
\hline Total employment $^{3}$ & 113.0 & 114.0 & 114.8 & 115.9 & 115.4 \\
\hline Formal employment & 92.2 & 92.6 & 93.1 & 93.4 & 92.1 \\
\hline Public sector & 29.3 & 27.4 & 27.8 & 28.0 & 27.5 \\
\hline Private sector & 62.9 & 65.2 & 65.3 & 65.4 & 64.6 \\
\hline Informal employment & 20.8 & 21.4 & 21.7 & 22.5 & 23.3 \\
\hline Unemployment rate (in percent) & 30.0 & 29.0 & 30.0 & 30.0 & 30.0 \\
\hline
\end{tabular}

Sources: Sources: World Bank's World Development Indicators; and staff estimates.

${ }^{1}$ National authorities, World Bank and staff estimates

${ }^{2}$ World Bank estimates.

${ }^{3}$ Ministry of Enterprise and Employment. 
Table 5. Swaziland: Developments in Crop Production, 2001/02-2006/07 ${ }^{1}$

\begin{tabular}{|c|c|c|c|c|c|c|}
\hline & $2001 / 02$ & $2002 / 03$ & $2003 / 04$ & $\begin{array}{r}2004 / 05 \\
\text { Proj. }\end{array}$ & $2005 / 06$ & $2006 / 07$ \\
\hline & \multicolumn{6}{|c|}{ (In thousands of metric tons) } \\
\hline \multicolumn{7}{|l|}{ Volume } \\
\hline Sugarcane & 4,179 & 4,609 & 5,046 & 4,884 & 5,144 & 4,931 \\
\hline Cotton & 3.9 & 3.5 & 2.8 & 5.0 & 0.9 & \\
\hline Maize & 67.7 & 62.5 & 71 & 75 & 67.1 & 69.2 \\
\hline $\mathrm{SNL}^{2}$ & 62.0 & 57.5 & 65.3 & 69.0 & 61.7 & 63.7 \\
\hline $\mathrm{TDL}^{3}$ & 5.7 & 5.0 & 5.7 & 6.0 & 5.4 & 5.5 \\
\hline Citrus fruit & 89.8 & 74.4 & 70.9 & 67.1 & 70.5 & 70.8 \\
\hline Tobacco & 0.1 & $\ldots$ & $\ldots$ & $\ldots$ & $\ldots$ & $\ldots$ \\
\hline & \multicolumn{6}{|c|}{ (In metric tons per hectare) } \\
\hline \multicolumn{7}{|l|}{ Yield } \\
\hline Sugarcane & 95.0 & 102.0 & 105.0 & 98.0 & 101.9 & 97.8 \\
\hline Cotton & 370.0 & 348.9 & $\ldots$ & & $\ldots$ & \\
\hline Maize & & & & & $\ldots$ & \\
\hline $\mathrm{SNL}^{2}$ & & $\ldots$ & $\ldots$ & $\ldots$ & $\ldots$ & ... \\
\hline $\mathrm{TDL}^{3}$ & 0.9 & $\ldots$ & $\ldots$ & $\ldots$ & $\ldots$ & ... \\
\hline Citrus fruit & 40.6 & $\ldots$ & $\ldots$ & $\ldots$ & $\ldots$ & ... \\
\hline & \multicolumn{6}{|c|}{ (In millions of emalangeni) } \\
\hline \multicolumn{7}{|l|}{ Value } \\
\hline Sugarcane & $5,887.0$ & $\ldots$ & $\ldots$ & & $\ldots$ & ... \\
\hline Cotton & 9.8 & 8.6 & 6.9 & 12.3 & 2.2 & \\
\hline Maize & 51.6 & 47.6 & 54.1 & 57.2 & 51.1 & 52.8 \\
\hline $\mathrm{SNL}^{2}$ & 46.5 & 42.9 & 48.7 & 51.4 & 46.0 & 47.5 \\
\hline $\mathrm{TDL}^{3}$ & 5.1 & 4.8 & 5.4 & 5.7 & 5.1 & 5.3 \\
\hline Citrus fruit & 146.6 & 122.2 & 99.8 & 97.8 & 95.8 & 116.6 \\
\hline
\end{tabular}

Source: Central Statistical Office and Swaziland Sugar Association.

${ }^{1}$ Variable crop years.

${ }^{2}$ Swazi Nation Land (SNL).

${ }^{3}$ Title Deed Land (TDL). 
Table 6. Developments in Sugar Production, Processing, and Consumption, 2001/02-2006/07

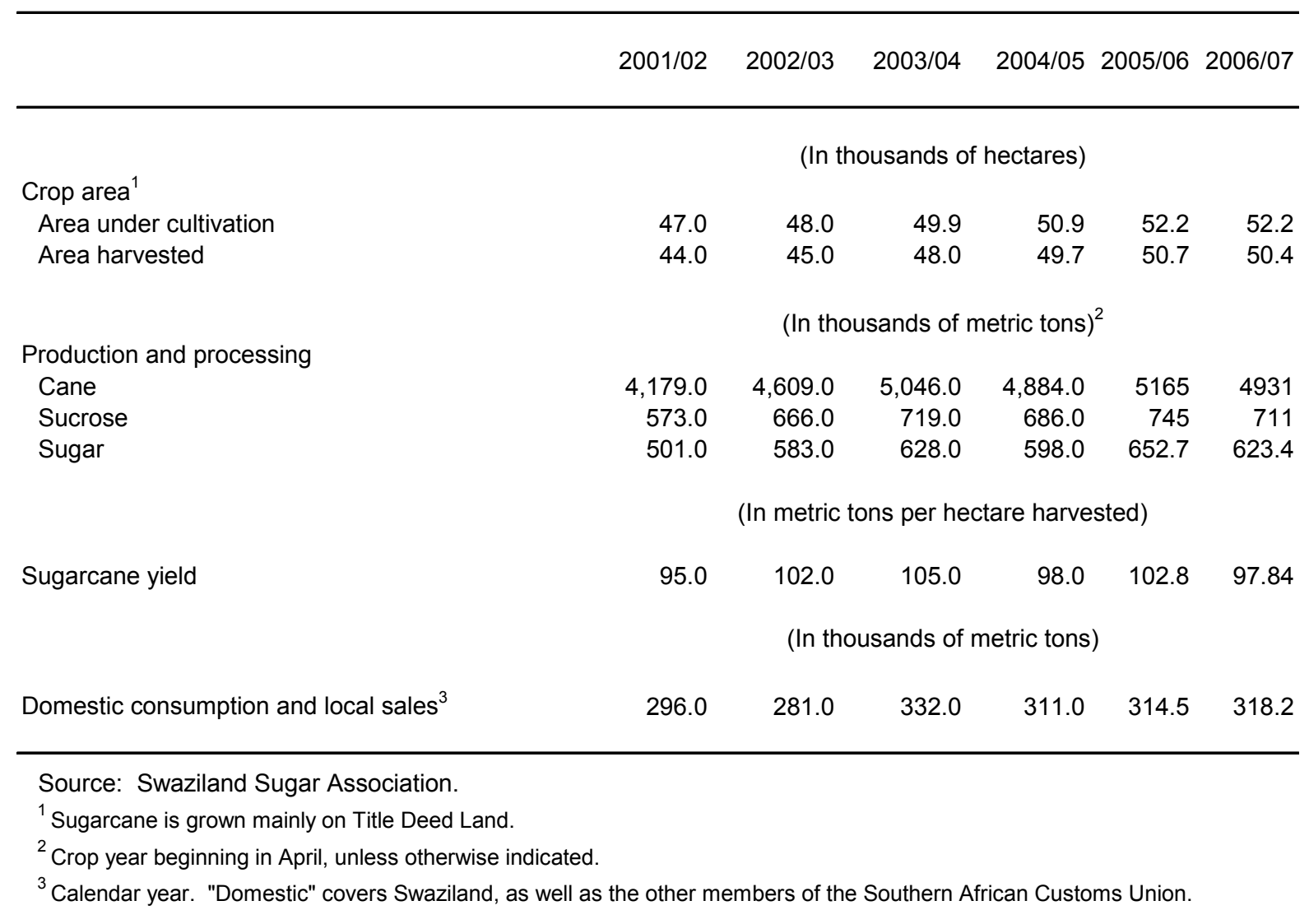


Table 7. Swaziland: Mineral Production and Exports, 2001-06

\begin{tabular}{|c|c|c|c|c|c|c|}
\hline & 2001 & 2002 & 2003 & 2004 & 2005 & 2006 \\
\hline & \multicolumn{6}{|c|}{ (In thousands of metric tons) } \\
\hline \multicolumn{7}{|l|}{ Production } \\
\hline Quarried stone $\left(\mathrm{M}^{3}\right)$ & & & & 230.1 & 566.8 & 534.7 \\
\hline Coal & 313.0 & $\begin{array}{l}553.4 \\
\text { (In th }\end{array}$ & $\begin{array}{l}448.7 \\
\text { ands of } E\end{array}$ & $\begin{array}{l}488.3 \\
\text { langeni) }\end{array}$ & 221.7 & 310.6 \\
\hline Exports & & & & & & \\
\hline Quarried stone & $\ldots$ & $\ldots$ & $\ldots$ & 12.4 & 15.3 & 18.4 \\
\hline Coal & 54.9 & 97.1 & 78.7 & 85.7 & 47.5 & 90.4 \\
\hline
\end{tabular}

Sources: Central Bank of Swaziland; and Geological Survey and Mines Department. 
Table 8. Swaziland: Electrical Power Generation and Demand, 2001-05

\begin{tabular}{|c|c|c|c|c|c|}
\hline & 2001 & 2002 & 2003 & 2004 & 2005 \\
\hline Total local production and imports ${ }^{1}$ & 846.9 & 893.0 & 994.1 & $1,020.3$ & 828.2 \\
\hline Local production ${ }^{2}$ & 205.6 & 203.7 & 123.0 & 103.5 & 159.5 \\
\hline Hydroelectric & 243.9 & 202.2 & 121.6 & $\ldots$ & 159.5 \\
\hline Diesel & 1.7 & 1.5 & 1.4 & $\ldots$ & $\ldots$ \\
\hline Imports (from ESKOM + STEM \& EDM) ${ }^{3}$ & 601.3 & 689.3 & 871.1 & 916.8 & 668.7 \\
\hline Total sales ${ }^{1}$ & 719.5 & 764.6 & 831.8 & 836.4 & 868 \\
\hline Household & 170.8 & 177.8 & 189.1 & 190.6 & 207.9 \\
\hline Commercial & 74.9 & 80.7 & 87.4 & 91.5 & 92.9 \\
\hline Irrigation power and bulk & 473.8 & 506.1 & 555.3 & 558.7 & 543.1 \\
\hline
\end{tabular}


Table 9. Swaziland: Retail Price Indices of Urban Families, 2002-06 ${ }^{1}$

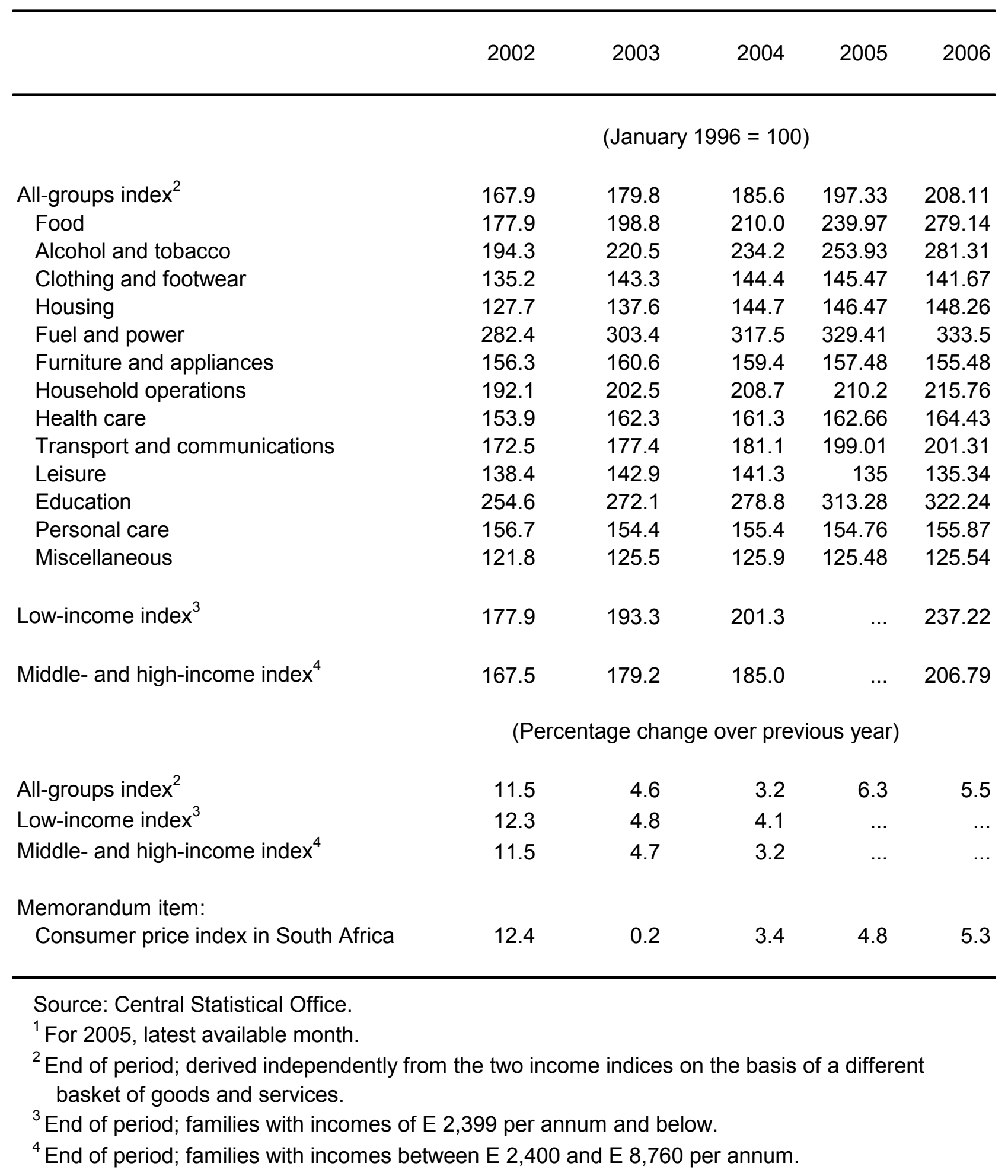


Table 10. Swaziland: Minimum Wages for General Workers in Selected Industries, 2001-06 ${ }^{1}$

\begin{tabular}{|c|c|c|c|c|c|}
\hline & 2002 & 2003 & 2004 & 2005 & 2006 \\
\hline \multicolumn{6}{|l|}{ Retail and wholesale } \\
\hline Mbabane and Manzini & 833.0 & 833.0 & 833.0 & 833.0 & 833.0 \\
\hline Elsewhere & 726.6 & 726.6 & 726.6 & 726.6 & 726.6 \\
\hline Manufacturing and processing & 131.1 & 131.1 & 131.1 & 131.1 & 131.1 \\
\hline Agriculture & 12.8 & 12.8 & 12.8 & 12.8 & 12.8 \\
\hline Building and construction & 4.1 & 4.1 & 4.1 & 4.1 & 4.1 \\
\hline Motor and engineering trades & 3.3 & 3.3 & 3.3 & 3.3 & 3.3 \\
\hline \multicolumn{6}{|l|}{ Retail and wholesale } \\
\hline Mbabane and Manzini & 0.0 & 0.0 & 0.0 & 0.0 & 0.0 \\
\hline Elsewhere & 0.0 & 0.0 & 0.0 & 0.0 & 0.0 \\
\hline Manufacturing and processing & 9.0 & 0.0 & 0.0 & 0.0 & 0.0 \\
\hline Agriculture & 0.0 & 0.0 & 0.0 & 0.0 & 0.0 \\
\hline Building and construction & 0.0 & 0.0 & 0.0 & 0.0 & 0.0 \\
\hline Motor and engineering trades & 0.0 & 0.0 & 0.0 & 0.0 & 0.0 \\
\hline
\end{tabular}

Source: Department of Labor.

${ }^{1}$ As of December of each year. 
Table 11. Swaziland: Paid Employment in the Private and Public Sectors by Industry, 2001-05 ${ }^{1}$ (In number of employees)

\begin{tabular}{|c|c|c|c|c|c|c|c|c|}
\hline & \multicolumn{2}{|c|}{2002} & \multicolumn{2}{|c|}{2003} & \multicolumn{2}{|c|}{2004} & \multicolumn{2}{|c|}{2005} \\
\hline & Private & Public & Private & Public & Private & Public & Private & Public \\
\hline Agriculture/forestry & 18,072 & 1,261 & 19,979 & 1,512 & 19,042 & 1,762 & 18,345 & 1,610 \\
\hline Mining and quarrying & 953 & 0 & 1,153 & 0 & 1,407 & 0 & 1,283 & 0 \\
\hline Manufacturing & 19,485 & 0 & 19,485 & 0 & 19,874 & 0 & 20,272 & 0 \\
\hline Electricity and water & 0 & 1,447 & 0 & 1,418 & 0 & 1,389 & & 859 \\
\hline Construction & 3,667 & 689 & 3,740 & 1,084 & 3,815 & 1,478 & 3,891 & 1,224 \\
\hline Distribution & 10,453 & 0 & 9,021 & 0 & 9,988 & 0 & 11,454 & 0 \\
\hline Transportation & 1,031 & 1,685 & 1,312 & 1,179 & 1,593 & 672 & 1,680 & 1,327 \\
\hline Finance & 6,546 & 1,095 & 5,508 & 914 & 4,470 & 732 & 5,583 & 847 \\
\hline Social services & 5,010 & 21,258 & 5,098 & 21,660 & 5,185 & 22,062 & 5,613 & 21,615 \\
\hline Total & 65,217 & 27,435 & 65,296 & 27,767 & 65,374 & 28,095 & 68,121 & 27,482 \\
\hline
\end{tabular}

Source: Ministry of Enterprise and Employment.

${ }^{1}$ Paid employment (including part-time) as of June of each year. 
Table 12. Swaziland: Summary of Central Government Operations, 2002/03-2006/07

\begin{tabular}{|c|c|c|c|c|c|}
\hline & $2002 / 03$ & $2003 / 04$ & $2004 / 05$ & $2005 / 06$ & $2006 / 07$ \\
\hline & \multicolumn{5}{|c|}{ (In millions of emalangeni) } \\
\hline Total revenue and grants & $3,425.9$ & $3,908.4$ & $4,841.8$ & $5,499.1$ & $8,021.0$ \\
\hline Tax revenue & $3,107.4$ & $3,660.5$ & $4,627.8$ & $5,189.5$ & $7,683.3$ \\
\hline SACU receipts & $1,618.6$ & $1,878.1$ & $2,772.8$ & $3,101.1$ & $5,321.8$ \\
\hline Non-SACU revenue & $1,488.8$ & $1,782.4$ & $1,855.0$ & $2,088.4$ & $2,361.5$ \\
\hline Nontax revenue & 155.4 & 110.2 & 98.0 & 137.3 & 172.1 \\
\hline Total expenditure and net lending & $4,018.2$ & $4,314.0$ & $5,557.0$ & $5,757.7$ & $6,052.1$ \\
\hline Current expenditure & $3,045.0$ & $3,437.2$ & $4,295.0$ & $4,416.3$ & $4,661.8$ \\
\hline Wages and salaries & $1,417.1$ & $1,668.9$ & $1,964.0$ & $2,443.0$ & $2,621.8$ \\
\hline Goods and services & 905.6 & $1,003.0$ & $1,421.0$ & 995.8 & $1,051.6$ \\
\hline Interest payments & 167.3 & 173.8 & 168.0 & 194.4 & 163.4 \\
\hline Subsidies and transfers & 555.0 & 591.5 & 742.0 & 783.1 & 824.9 \\
\hline Capital expenditure & 935.5 & 817.8 & $1,259.0$ & $1,409.7$ & $1,411.8$ \\
\hline Net lending & 37.7 & 59.0 & 3.0 & -68.3 & -21.6 \\
\hline Primary balance & -425.0 & -231.8 & -547.2 & -64.2 & $2,132.4$ \\
\hline Overall balance (including grants) & -592.3 & -405.6 & -715.2 & -258.7 & $1,969.0$ \\
\hline Overall balance (excluding grants) & -755.4 & -543.3 & -831.2 & -430.9 & $1,803.3$ \\
\hline Financing & 592.3 & 405.6 & 715.2 & 258.7 & $-1,969.0$ \\
\hline Foreign (net) & 218.4 & 77.0 & 255.0 & 211.5 & $-1,090.0$ \\
\hline Domestic (net) 2/ & 373.9 & 328.6 & 460.3 & 47.1 & -879.0 \\
\hline Government debt & $2,850.1$ & $2,955.3$ & $2,800.7$ & $2,729.9$ & $3,251.7$ \\
\hline Foreign & $2,499.7$ & $2,455.0$ & $2,293.3$ & $2,303.0$ & $2,742.3$ \\
\hline \multirow[t]{2}{*}{ Domestic } & 350.4 & 500.2 & 507.4 & 426.9 & 509.4 \\
\hline & \multicolumn{5}{|c|}{ (In percent of GDP, unless otherwise specified) } \\
\hline Total revenue and grants & 26.7 & 27.6 & 30.9 & 32.0 & 41.5 \\
\hline Tax revenue & 24.2 & 25.8 & 29.5 & 30.2 & 39.8 \\
\hline SACU receipts & 12.6 & 13.3 & 17.7 & 18.1 & 27.5 \\
\hline Non-SACU revenue & 11.6 & 12.6 & 11.8 & 12.2 & 12.2 \\
\hline Nontax revenue & 1.2 & 0.8 & 0.6 & 0.8 & 0.9 \\
\hline Grants & 1.3 & 1.0 & 0.7 & 1.0 & 0.9 \\
\hline Total expenditure and net lending & 31.3 & 30.4 & 35.5 & 33.5 & 31.3 \\
\hline Current expenditure & 23.7 & 24.3 & 27.4 & 25.7 & 24.1 \\
\hline \multicolumn{6}{|l|}{ Of which: } \\
\hline Wages and salaries & 11.0 & 11.8 & 12.5 & 14.2 & 13.6 \\
\hline Goods and services & 7.1 & 7.1 & 9.1 & 5.8 & 5.4 \\
\hline Interest payments & 1.3 & 1.2 & 1.1 & 1.1 & 0.8 \\
\hline Subsidies and transfers & 4.3 & 4.2 & 4.7 & 4.6 & 4.3 \\
\hline Capital expenditure & 7.3 & 5.8 & 8.0 & 8.2 & 7.3 \\
\hline Primary balance & -3.3 & -1.6 & -3.5 & -0.4 & 11.0 \\
\hline Overall balance (including grants) & -4.6 & -2.9 & -4.6 & -1.5 & 10.2 \\
\hline Overall balance (excluding grants) & -5.9 & -3.8 & -5.3 & -2.5 & 9.3 \\
\hline Financing & 4.6 & 2.9 & 4.6 & 1.5 & -10.2 \\
\hline Foreign (net) & 1.7 & 0.5 & 1.6 & 1.2 & -5.6 \\
\hline Domestic (net) & 2.9 & 2.3 & 2.9 & 0.3 & -4.5 \\
\hline Government debt & 22.2 & 20.9 & 17.9 & 15.9 & 16.8 \\
\hline Foreign & 19.5 & 17.3 & 14.6 & 13.4 & 14.2 \\
\hline Domestic & 2.7 & 3.5 & 3.2 & 2.5 & 2.6 \\
\hline \multicolumn{6}{|l|}{ Memorandum items: } \\
\hline Payment arrears & $\ldots$ & 0.8 & 2.0 & & \\
\hline GDP at current prices (in millions of emalangeni) & 12,833 & 14,169 & 15,669 & 17,176 & 19,323 \\
\hline Wages and salaries (in percent of current expenditure' & 46.5 & 48.6 & 45.7 & 55.3 & 56.2 \\
\hline
\end{tabular}

Sources: Ministry of Finance; and Fund staff projections.

${ }^{1}$ The fiscal year runs from April 1 to March 31 . 
Table 13. Swaziland: Central Government Revenue and Grants, 2002/03-2006/07

\begin{tabular}{|c|c|c|c|c|c|}
\hline & $2002 / 03$ & $2003 / 04$ & $2004 / 05$ & $2005 / 06$ & $2006 / 07$ \\
\hline \multicolumn{6}{|c|}{ (In millions of emalangeni) } \\
\hline Tax revenue & $3,107.4$ & $3,660.5$ & $4,627.8$ & $5,189.5$ & $7,683.3$ \\
\hline Taxes on net income and profits & 827.5 & $1,105.4$ & $1,164.0$ & $1,267.4$ & $1,534.0$ \\
\hline Companies & 259.6 & 322.4 & 324.0 & 472.5 & 598.0 \\
\hline Individuals & 494.1 & 698.7 & 742.0 & 761.7 & 891.9 \\
\hline Nonresident dividends and interest & 73.8 & 84.3 & 98.0 & 33.3 & 44.1 \\
\hline Taxes on property & 6.0 & 9.0 & 12.0 & 13.3 & 17.4 \\
\hline Taxes on goods, services, and international trad & $2,269.2$ & $2,540.8$ & $3,445.8$ & $3,894.4$ & $6,118.7$ \\
\hline Southern African Customs Union (SACU) recei & $1,618.6$ & $1,878.1$ & $2,772.8$ & $3,101.1$ & $5,321.8$ \\
\hline Sugar export levy & 21.8 & 12.1 & 22.0 & 21.1 & 33.1 \\
\hline Hotel and gaming taxes & 3.7 & 4.4 & 5.0 & 7.8 & 9.6 \\
\hline Licenses and other taxes & 96.6 & 98.5 & 97.0 & 29.4 & 134.0 \\
\hline Sales tax & 528.6 & 547.7 & 549.0 & 734.9 & 620.1 \\
\hline Road levy and oil tax & 0.0 & 0.0 & 0.0 & 0.0 & 0.0 \\
\hline Other taxes & 4.7 & 5.3 & 6.0 & 14.4 & 13.3 \\
\hline Nontax revenue & 157.1 & 104.9 & 98.0 & 137.3 & 172.1 \\
\hline Property income & 108.6 & 52.0 & 46.0 & 53.4 & 88.6 \\
\hline Fees, fines, and nonindustrial sales & 48.5 & 52.9 & 52.0 & 83.9 & 83.5 \\
\hline Total revenue & $3,264.5$ & $3,765.4$ & $4,725.8$ & $5,326.8$ & $7,855.4$ \\
\hline Grants & 163.0 & 137.7 & 116.0 & 172.2 & 165.6 \\
\hline \multirow[t]{2}{*}{ Total revenue and grants } & $3,427.6$ & $3,903.1$ & $4,841.8$ & $5,499.1$ & $8,021.0$ \\
\hline & \multicolumn{3}{|c|}{ (In percent of GDP) } & & \\
\hline Tax revenue & 24.2 & 25.8 & 29.5 & 30.2 & 39.8 \\
\hline Taxes on net income and profits & 6.4 & 7.8 & 7.4 & 7.4 & 7.9 \\
\hline \multicolumn{6}{|l|}{ Of which } \\
\hline Companies & 2.0 & 2.3 & 2.1 & 2.8 & 3.1 \\
\hline Individuals & 3.9 & 4.9 & 4.7 & 4.4 & 4.6 \\
\hline Taxes on property & 0.0 & 0.1 & 0.1 & 0.1 & 0.1 \\
\hline $\begin{array}{l}\text { Taxes on goods, services, and international trad } \epsilon \\
\text { Of which }\end{array}$ & 17.7 & 17.9 & 22.0 & 22.7 & 31.7 \\
\hline SACU receipts & 12.6 & 13.3 & 17.7 & 18.1 & 27.5 \\
\hline Sales tax & 4.1 & 3.9 & 3.5 & 4.3 & 3.2 \\
\hline Other taxes & 0.0 & 0.0 & 0.0 & 0.1 & 0.1 \\
\hline Nontax revenue & 1.2 & 0.7 & 0.6 & 0.8 & 0.9 \\
\hline Grants & 1.3 & 1.0 & 0.7 & 1.0 & 0.9 \\
\hline \multirow[t]{2}{*}{ Total revenue and grants } & 26.7 & 27.5 & 30.9 & 32.0 & 41.5 \\
\hline & \multicolumn{5}{|c|}{ In percent of total revenue and grants) } \\
\hline Tax revenue & 90.7 & 93.8 & 95.6 & 94.4 & 95.8 \\
\hline Taxes on net income and profits & 24.1 & 28.3 & 24.0 & 23.0 & 19.1 \\
\hline Of which & & & & & \\
\hline Companies & 7.6 & 8.3 & 6.7 & 8.6 & 7.5 \\
\hline Individuals & 14.4 & 17.9 & 15.3 & 13.9 & 11.1 \\
\hline Taxes on property & 0.2 & 0.2 & 0.2 & 0.2 & 0.2 \\
\hline Taxes on goods, services, and international trad $\epsilon$ & 66.2 & 65.1 & 71.2 & 70.8 & 76.3 \\
\hline Of which: SACU receipts & 47.2 & 48.1 & 57.3 & 56.4 & 66.3 \\
\hline Other taxes & 0.1 & 0.1 & 0.1 & 0.3 & 0.2 \\
\hline Nontax revenue & 4.6 & 2.7 & 2.0 & 2.5 & 2.1 \\
\hline Grants & 4.8 & 3.5 & 2.4 & 3.1 & 2.1 \\
\hline \multicolumn{6}{|l|}{ Memorandum item: } \\
\hline GDP at current market prices (in millions of emal: & $12,832.9$ & $14,169.3$ & $15,669.2$ & $17,176.0$ & $19,322.7$ \\
\hline
\end{tabular}

Source: Ministry of Finance.

${ }^{1}$ Fiscal year runs from April 1 to March 31. 
Table 14. Swaziland: Functional Classification of Central Government Expenditure and Net Lending, 2002/03-2006/07 ${ }^{1}$

\begin{tabular}{|c|c|c|c|c|c|}
\hline & $2002 / 03$ & $2003 / 04$ & $2004 / 05$ & $2005 / 06$ & $2006 / 07$ \\
\hline & \multicolumn{5}{|c|}{ (In millions of emalangeni) } \\
\hline Current expenditure & $3,045.0$ & $3,437.2$ & $4,295.0$ & $4,416.3$ & $4,661.8$ \\
\hline Wages and salaries & $1,417.1$ & $1,668.9$ & $1,964.0$ & $2,443.0$ & $2,621.8$ \\
\hline Of which: Health & 101.0 & 131.0 & 165.2 & 185.5 & 194.8 \\
\hline Education & 488.0 & 575.0 & 715.4 & 675.8 & 770.1 \\
\hline Other purchases of goods and services & 905.6 & $1,003.0$ & $1,421.0$ & 995.8 & $1,051.6$ \\
\hline Of which: Health & 93.0 & 119.0 & 142.8 & 152.9 & 130.8 \\
\hline Education & 39.0 & 64.0 & 69.1 & 75.4 & 86.0 \\
\hline Interest payments & 167.3 & 173.8 & 168.0 & 194.4 & 163.4 \\
\hline Domestic & 0.0 & 37.0 & 49.0 & 31.6 & 35.3 \\
\hline Foreign & 167.3 & 136.8 & 119.0 & 162.9 & 128.1 \\
\hline Subsidies and other current transfers & 555.0 & 591.5 & 742.0 & 783.1 & 824.9 \\
\hline Of which: subsidies to NFPEs ${ }^{2}$ & 246.5 & 200.7 & 213.2 & 287.2 & 289.0 \\
\hline Capital expenditure & 935.5 & 817.8 & $1,259.0$ & $1,409.7$ & $1,411.8$ \\
\hline Of which: Health & 22.0 & 60.0 & 82.6 & 47.8 & 95.4 \\
\hline Education & 48.0 & 13.0 & 27.9 & 18.9 & 32.9 \\
\hline Agriculture & 31.0 & 48.0 & 104.5 & 171.6 & 122.7 \\
\hline Transport and communications & 427.0 & 125.0 & 347.6 & 387.0 & 381.1 \\
\hline Other & 407.5 & 571.8 & 696.4 & 784.4 & 779.7 \\
\hline Net lending & 37.7 & 59.0 & 3.0 & -68.3 & -21.6 \\
\hline Gross lending & 44.3 & 68.3 & 10.0 & 0.0 & 0.0 \\
\hline Repayments & -6.5 & -9.3 & -7.0 & -68.3 & -21.6 \\
\hline \multirow[t]{2}{*}{ Total expenditure and net lending } & $4,018.2$ & $4,314.0$ & $5,557.0$ & $5,757.7$ & $6,052.1$ \\
\hline & \multicolumn{5}{|c|}{ (In percent of GDP) } \\
\hline Current expenditure & 23.7 & 24.3 & 27.4 & 25.7 & 24.1 \\
\hline Capital expenditure & 7.3 & 5.8 & 8.0 & 8.2 & 7.3 \\
\hline Net lending & 0.3 & 0.4 & 0.0 & -0.4 & -0.1 \\
\hline Total expenditure and net lending & 31.3 & 30.4 & 35.5 & 33.5 & 31.3 \\
\hline & \multicolumn{5}{|c|}{ (In percent of total expenditure an net lending) } \\
\hline Current expenditure & 75.8 & 79.7 & 77.3 & 76.7 & 77.0 \\
\hline Wages and salaries & 35.3 & 38.7 & 35.3 & 42.4 & 43.3 \\
\hline Other purchases of goods and services & 22.5 & 23.2 & 25.6 & 17.3 & 17.4 \\
\hline Interest payments & 4.2 & 4.0 & 3.0 & 3.4 & 2.7 \\
\hline Subsidies and other current transfers & 13.8 & 13.7 & 13.4 & 13.6 & 13.6 \\
\hline Capital expenditure & 23.3 & 19.0 & 22.7 & 24.5 & 23.3 \\
\hline Net lending & 0.9 & 1.4 & 0.1 & -1.2 & -0.4 \\
\hline \multicolumn{6}{|l|}{ Memorandum item: } \\
\hline GDP at current market prices (in millions of emalangeni) & $12,832.9$ & $14,169.3$ & $15,669.2$ & $17,176.0$ & $19,322.7$ \\
\hline
\end{tabular}

Source: Ministry of Finance.

${ }^{1}$ Fiscal year runs from April 1 to March 31.

${ }^{2}$ NFPEs (nonfinancial public enterprises). 
Table 15. Swaziland: Economic Classification of Government Current Expenditure, 2002/03-2006/07 ${ }^{1}$

\begin{tabular}{|c|c|c|c|c|c|}
\hline & $2002 / 03$ & $2003 / 04$ & $2004 / 05$ & $2005 / 06$ & $\begin{array}{c}2006 / 07 \\
\text { Est. }\end{array}$ \\
\hline & \multicolumn{5}{|c|}{ (In millions of emalangeni) } \\
\hline General public service & $1,213.0$ & $1,183.0$ & $1,448.4$ & 1379.9 & 1433.7 \\
\hline General administration & 907.0 & 495.0 & 962.9 & 789.0 & 830.31 \\
\hline Public order and safety & 306.0 & 688.0 & 485.4 & 590.9 & 603.4 \\
\hline Defense & 202.0 & 255.0 & 282.8 & 410.0 & 391.7 \\
\hline Social services & $1,047.6$ & $1,358.0$ & $1,653.0$ & $1,853.6$ & $2,089.7$ \\
\hline Education & 711.0 & 911.0 & $1,130.3$ & $1,178.5$ & $1,308.9$ \\
\hline Health & 239.6 & 291.0 & 348.0 & 492.8 & 521.67 \\
\hline Other & 97.0 & 156.0 & 174.7 & 182.3 & 259.1 \\
\hline Economic services & 415.4 & 507.2 & 742.7 & 578.4 & 583.3 \\
\hline Agriculture & 120.8 & 147.0 & 203.0 & 159.5 & 153.4 \\
\hline Manufacturing, mining, and construction & 46.8 & 58.0 & 69.0 & 13.3 & 13.1 \\
\hline Water and sewerage & 24.0 & 31.0 & 36.0 & 56.3 & 53.7 \\
\hline Transport and communications & 231.0 & 187.0 & 231.0 & 205.4 & 163.3 \\
\hline Other & -7.2 & 84.2 & 203.7 & 143.9 & 199.8 \\
\hline Interest payments & 167.0 & 134.0 & 168.0 & 194.4 & 163.4 \\
\hline \multirow[t]{2}{*}{ Total } & $3,045.0$ & $3,437.2$ & $4,294.9$ & $4,416.3$ & $4,661.8$ \\
\hline & \multicolumn{5}{|c|}{ (In percent of GDP) } \\
\hline General public service & 9.5 & 8.3 & 9.2 & 8.0 & 7.4 \\
\hline General administration & 7.1 & 3.5 & 6.1 & 4.6 & 4.3 \\
\hline Public safety and defense & 2.4 & 4.9 & 3.1 & 3.4 & 3.1 \\
\hline Defense & 1.6 & 1.8 & 1.8 & 2.4 & 2.0 \\
\hline Social services & 8.2 & 9.6 & 10.5 & & \\
\hline Education & 5.5 & 6.4 & 7.2 & 6.9 & 6.8 \\
\hline Health & 1.9 & 2.1 & 2.2 & 2.9 & 2.7 \\
\hline Other & 0.8 & 1.1 & 1.1 & 1.1 & 1.3 \\
\hline Economic services & 3.2 & 3.6 & 4.7 & 3.4 & 3.0 \\
\hline \multirow[t]{2}{*}{ Interest payments } & 1.3 & 0.9 & 1.1 & 1.1 & 0.8 \\
\hline & \multicolumn{5}{|c|}{ (In percent of total current expenditure) } \\
\hline General public service & 39.8 & 34.4 & 33.7 & 31.2 & 30.8 \\
\hline General administration & 29.8 & 14.4 & 22.4 & 17.9 & 17.8 \\
\hline Public safety and defense & 10.0 & 20.0 & 11.3 & 13.4 & 12.9 \\
\hline Defense & 6.6 & 7.4 & 6.6 & 9.3 & 8.4 \\
\hline Social services & 34.4 & 39.5 & 38.5 & 42.0 & 44.8 \\
\hline Education & 23.4 & 26.5 & 26.3 & 26.7 & 28.1 \\
\hline Health & 7.9 & 8.5 & 8.1 & 11.2 & 11.2 \\
\hline Other & 3.2 & 4.5 & 4.1 & 4.1 & 5.6 \\
\hline Economic services & 13.6 & 14.8 & 17.3 & 13.1 & 12.5 \\
\hline Interest payments & 5.5 & 3.9 & 3.9 & 4.4 & 3.5 \\
\hline \multicolumn{6}{|l|}{ Memorandum item: } \\
\hline GDP at current market prices (in millions of emalal & $12,832.9$ & $14,169.3$ & $15,669.2$ & $17,176.0$ & $19,322.7$ \\
\hline
\end{tabular}

Source: Ministry of Finance.

' Fiscal year runs from April 1 to March 31. 
Table 16. Swaziland: Capital Expenditure by Sector, 2002/03-2006/07 ${ }^{1}$

(In millions of emalangeni)

\begin{tabular}{|c|c|c|c|c|c|}
\hline & $2002 / 03$ & $2003 / 04$ & $2004 / 05$ & $2005 / 06$ & $2006 / 07$ \\
\hline General public services & 277.0 & 67.0 & 408.1 & 492.5 & 472.0 \\
\hline General administration & 225.0 & 28.0 & 365.6 & 398.2 & 149.9 \\
\hline Public safety and defense & 52.0 & 39.0 & 42.5 & 94.3 & 56.6 \\
\hline Social services & 137.0 & 282.0 & 360.0 & 291.4 & 232.6 \\
\hline Education & 48.0 & 13.0 & 28.0 & 18.9 & 32.9 \\
\hline Health & 22.0 & 60.0 & 83.0 & 47.8 & 48.5 \\
\hline Housing & 62.0 & 193.0 & 247.0 & 179.3 & 123.8 \\
\hline Recreation and culture & 0.0 & 7.0 & 1.1 & 13.2 & 18.1 \\
\hline Other & 5.0 & 9.0 & 0.9 & 32.2 & 9.3 \\
\hline Economic services & 521.5 & 468.8 & 490.9 & 625.7 & 707.3 \\
\hline Agriculture & 31.0 & 48.0 & 105.0 & 171.6 & 122.7 \\
\hline Industry and mining & 4.0 & 4.0 & 23.0 & 6.0 & 27.1 \\
\hline Water and sewage & 12.0 & 13.0 & 9.0 & 56.5 & 162.4 \\
\hline Transport and communications & 427.0 & 125.0 & 348.0 & 387.0 & 381.1 \\
\hline Other & 47.5 & 278.8 & 5.9 & 4.6 & 14.1 \\
\hline Total capital expenditure & 935.5 & 817.8 & $1,259.0$ & 1409.6 & 1411.8 \\
\hline
\end{tabular}

Source: Ministry of Finance.

${ }^{1}$ Fiscal year runs from April 1 to March 31. 
Table 17. Swaziland: Government Transfer Payments, 2002/03-2006/07 ${ }^{1}$

(In millions of emalangeni, unless otherwise indicated)

\begin{tabular}{|c|c|c|c|c|c|}
\hline & $2002 / 03$ & $2003 / 04$ & $2004 / 05$ & $2005 / 06$ & $2006 / 07$ \\
\hline Grants to students & 68.5 & 109.0 & 139.9 & 147.8 & 128.0 \\
\hline Grants to mission hospital & 37.2 & 42.1 & 41.9 & 39.0 & 41.6 \\
\hline Public assistance & 0.8 & 2.2 & 5.5 & 6.3 & 46.4 \\
\hline Grants to town councils & 30.1 & 38.7 & 39.7 & 47.8 & 56.9 \\
\hline Grants to youth and sports & 5.1 & 5.0 & 5.0 & 0.0 & 2.1 \\
\hline External transfers ${ }^{2}$ & 24.4 & 29.4 & 29.0 & 21.3 & 19.4 \\
\hline Swaziland National Treasury & 57.4 & 54.4 & 51.9 & 83.7 & 141.0 \\
\hline Cattle-dipping chemicals & 5.5 & 5.5 & 7.6 & 8.4 & 0 \\
\hline Swaziland Komati Project Enterprise & 7.8 & 9.2 & 9.2 & 8.3 & 13.2 \\
\hline Education Fund for Orphaned \& Disadvantaged Children & & & & & 47.1 \\
\hline Manzini Industrial Training Centre & & & & & 3.4 \\
\hline Other ${ }^{3}$ & 140.1 & 125.9 & 412.6 & 420.5 & 289.0 \\
\hline Total & 376.9 & 421.4 & 742.1 & 783.1 & 788.1 \\
\hline \multicolumn{6}{|l|}{ Memorandum item: } \\
\hline Transfers (in percent of GDP) & 2.9 & 3.0 & 4.7 & 4.6 & 4.1 \\
\hline Nominal GDP (in millions of emalangeni) & 12,833 & 14,169 & 15,669 & 17,176 & 19,323 \\
\hline
\end{tabular}

Source: Ministry of Finance.

${ }^{1}$ Fiscal year runs from April 1 to March 31.

${ }^{2}$ Subscriptions to international organizations.

${ }^{3}$ Includes transfers and subsidies to nonfinancial publlic enterprises. 
Table 18. Swaziland: Flow of Funds From the Government to Public Enterprises 2002/03-2006/2007 (In millions of emalangeni, unless otherwise indicated)

\begin{tabular}{|c|c|c|c|c|c|}
\hline & $2002 / 03$ & $2003 / 04$ & $2004 / 05$ & $2005 / 06$ & $2006 / 07$ \\
\hline Total subsidies to public enterprises & 306.5 & 200.7 & 213.2 & 287.2 & 289.0 \\
\hline Operating/Transport subsidy & 175.8 & 169.5 & 172.5 & 187.4 & \\
\hline Capital subsidy (flow) & 130.7 & 31.2 & 40.7 & 99.8 & \\
\hline Total subsidies to public enterprises & 306.5 & 200.7 & 213.2 & 287.2 & 289.0 \\
\hline Swaziland Development \& Savings Bank & 60.0 & 0.0 & 0.0 & 0.0 & 0.0 \\
\hline Subsidies to nonfinancial public enterprises & 246.5 & 200.7 & 213.2 & 287.2 & 289.0 \\
\hline Joint Venture Capital Fund & 0.0 & 0.0 & 0.0 & 0.0 & 0.0 \\
\hline Swaziland Water Services Corporation & 9.9 & 0.0 & 0.0 & 36.5 & 13.2 \\
\hline Swaziland Investment Promotion Authority & 4.6 & 3.9 & 4.7 & 7.8 & 25.2 \\
\hline Swaziland Television Authority & 10.1 & 10.1 & 10.1 & 32.6 & 29.3 \\
\hline Sebenta National Institute & 3.0 & 2.7 & 2.7 & 2.9 & 2.9 \\
\hline Swaziland National Trust Commission & 7.2 & 7.3 & 8.3 & 25.3 & 11.9 \\
\hline University of Swaziland & 92.4 & 109.3 & 109.3 & 109.3 & 130.8 \\
\hline Motor Vehicle Accident Fund & 28.0 & 0.0 & 0.0 & 0.0 & 0.0 \\
\hline Swaziland Water \& Agricultural Development Enterprise (wa: & 57.5 & 38.6 & 38.6 & 28.7 & 22.0 \\
\hline Commission for Mediation etc. & 2.2 & 2.6 & 5.4 & 7.2 & 5.8 \\
\hline National Emergency Response Committee & 20.0 & 20.0 & 20.0 & 20.0 & 30.3 \\
\hline Swailand Environment Authority & 0.0 & 0.0 & 0.0 & 0.0 & 1.5 \\
\hline Swaziland Tourism Authority & 0.0 & 0.0 & 0.0 & 3.8 & 7.8 \\
\hline Swaziland Cotton Board (Revolving Fund) & 0.0 & 0.0 & 0.0 & 0.0 & 1.0 \\
\hline Swaziland Standards Authority & 0.0 & 0.0 & 0.0 & 0.0 & 1.0 \\
\hline Small Enterprises Development Company & & & & 3.7 & 3.7 \\
\hline Other & 11.6 & 6.2 & 14.1 & 16.9 & 2.7 \\
\hline \multicolumn{6}{|l|}{ Memorandum item: } \\
\hline Total Subsidies (in percent of GDP) & 2.4 & 1.4 & 1.4 & 1.7 & 1.5 \\
\hline Nominal GDP (in millions of emalangeni) & 12,833 & 14,169 & 15,669 & $17,176.0$ & $19,322.7$ \\
\hline
\end{tabular}

Source: Ministry of Finance.

${ }^{1}$ Fiscal year runs from April 1 to March 31. 
Table 19. Swaziland: Outstanding Domestic Government Debt by Type of Instrument, 2002-November 2007 (In millions of emalangeni; end of period)

\begin{tabular}{|c|c|c|c|c|c|c|}
\hline & 2002 & 2003 & 2004 & 2005 & 2006 & Nov-07 \\
\hline Government bonds and stocks & 260.0 & 260.0 & 180.0 & 99.0 & 50.0 & 50.0 \\
\hline Central Bank of Swaziland & 0.0 & 0.0 & 0.0 & 19.0 & 0.0 & 0.0 \\
\hline Banks & 176.7 & 176.7 & 146.3 & 59.3 & 39.0 & 39.0 \\
\hline Other financial institutions & 53.9 & 53.9 & 14.5 & 6.5 & 5.0 & 5.0 \\
\hline Other & 29.4 & 29.4 & 19.2 & 14.2 & 6.0 & 6.0 \\
\hline Treasury bills ${ }^{1}$ & 40.0 & 217.7 & 374.0 & 427.3 & 422.0 & 381.7 \\
\hline Central Bank of Swaziland & 0.0 & 40.0 & 73.0 & 50.0 & 55.7 & 15.0 \\
\hline Banks & 40.0 & 160.0 & 280.0 & 234.4 & 337.2 & 354.1 \\
\hline Other & 0.0 & 17.7 & 21.0 & 143.0 & 29.1 & 12.6 \\
\hline $\begin{array}{l}\text { Total domestic government debt } \\
\text { By original maturity }\end{array}$ & 300.0 & 477.7 & 554.0 & 507.3 & 472.0 & 431.7 \\
\hline Less than one year & 40.0 & 217.7 & 374.0 & 427.3 & 422.0 & 381.7 \\
\hline From one to five years & 210.0 & 210.0 & 130.0 & 0.0 & 0.0 & 0.0 \\
\hline From five to ten years & 50.0 & 50.0 & 50.0 & 80.0 & 50.0 & 50.0 \\
\hline Over ten years & 0.0 & 0.0 & 0.0 & 0.0 & 0.0 & 0.0 \\
\hline
\end{tabular}

Source: Central Bank of Swaziland.

${ }^{1}$ The maturity of treasury bills is three months. 
Table 20. Swaziland: Monetary Survey, 2002-07 ${ }^{1}$

\begin{tabular}{|c|c|c|c|c|c|c|}
\hline & 2002 & 2003 & 2004 & 2005 & 2006 & $\begin{array}{r}2007 \\
\text { Oct. }\end{array}$ \\
\hline & \multicolumn{6}{|c|}{ (In millions of Emalangeni) } \\
\hline \multicolumn{7}{|l|}{ Monetary authorities } \\
\hline Net foreign assets & $1,873.5$ & $1,404.7$ & $1,450.2$ & $1,518.4$ & $2,292.6$ & $4,222.7$ \\
\hline Central Bank of Swaziland (CBS) & $1,863.3$ & $1,378.2$ & $1,243.3$ & $1,518.4$ & $2,257.2$ & $3,525.1$ \\
\hline Of which: Capital Investment Fund (CIF), managed by CBS. & $1,219.7$ & 712.9 & 666.7 & 0.0 & 0.0 & 0.0 \\
\hline Government $^{2}$ & 10.2 & 26.5 & 206.9 & 0.0 & 35.4 & 697.6 \\
\hline Net domestic assets & $-1,543.7$ & -974.8 & -973.2 & $-1,020.8$ & $-1,723.2$ & $-3,496.2$ \\
\hline Central government (net) & $-1,299.7$ & $-1,030.8$ & -933.2 & $-1,082.5$ & $-1,960.0$ & $-3,589.3$ \\
\hline CBS claims on government & 57.3 & 82.6 & 251.8 & 100.6 & 55.1 & 22.5 \\
\hline Government deposits & $-1,357.0$ & $-1,113.4$ & $-1,185.0$ & $-1,183.0$ & $-2,015.1$ & $-3,611.8$ \\
\hline Domestic & -127.1 & -374.0 & -311.3 & $-1,183.0$ & $-1,976.1$ & $-2,910.8$ \\
\hline Foreign $^{2}$ & $-1,229.9$ & -739.4 & -873.6 & 0.0 & -38.9 & -701.0 \\
\hline Private sector & 13.0 & 12.0 & 10.0 & 8.9 & 20.5 & 7.9 \\
\hline Commercial banks (net) & 0.0 & 0.0 & 0.0 & 2.3 & 313.8 & 276.1 \\
\hline Other items (net) & -257.0 & 44.0 & -50.0 & 50.5 & -97.5 & -190.9 \\
\hline Reserve money & 329.4 & 430.3 & 477.1 & 489.9 & 566.1 & 725.0 \\
\hline \multicolumn{7}{|l|}{ Commercial banks } \\
\hline Net foreign assets & 715.0 & 469.4 & 490.4 & 374.5 & 761.9 & $1,005.9$ \\
\hline Reserves & 176.0 & 194.0 & 211.0 & 210.5 & 353.6 & 500.3 \\
\hline Domestic credit & $1,985.3$ & $2,614.1$ & $3,344.2$ & $3,832.3$ & $4,581.2$ & $5,329.1$ \\
\hline Central government (net) & 215.2 & 286.4 & 331.0 & 301.7 & 305.5 & 203.4 \\
\hline Claims on Government & 215.4 & 286.7 & 332.5 & 315.0 & 369.4 & 368.2 \\
\hline Government deposits & 0.2 & 0.3 & 1.5 & 13.3 & 63.8 & 164.8 \\
\hline Private sector & $1,770.1$ & $2,327.7$ & $3,013.2$ & $3,530.6$ & $4,275.7$ & $5,125.7$ \\
\hline Other items (net) & -519.0 & -613.0 & $-1,100.0$ & $-1,196.1$ & $-1,588.6$ & $-1,581.3$ \\
\hline Private sector deposits & $2,357.0$ & $2,663.7$ & $2,945.9$ & $3,221.2$ & $4,088.2$ & $5,254.0$ \\
\hline \multicolumn{7}{|l|}{ Monetary survey } \\
\hline Net foreign assets & $2,588.5$ & $1,874.1$ & $1,940.6$ & $1,892.9$ & $3,054.6$ & $5,228.6$ \\
\hline Domestic credit & 698.7 & $1,595.3$ & $2,421.0$ & $2,758.7$ & $2,641.7$ & $1,747.6$ \\
\hline Central government (net) & $-1,084.5$ & -744.4 & -602.2 & -780.8 & $-1,654.4$ & $-3,385.9$ \\
\hline Private sector & $1,783.1$ & $2,339.7$ & $3,023.2$ & $3,539.5$ & $4,296.2$ & $5,133.5$ \\
\hline Other items (net) & -684.7 & -500.4 & $-1,083.6$ & $-1,180.5$ & $-1,354.4$ & $-1,470.9$ \\
\hline Broad money & $2,602.4$ & $2,969.0$ & $3,278.0$ & $3,471.0$ & $4,342.0$ & $5,505.3$ \\
\hline Currency in circulation ${ }^{3}$ & 155.4 & 213.5 & 235.8 & 242.1 & 250.5 & 249.9 \\
\hline \multirow[t]{2}{*}{ Deposits } & $2,447.0$ & $2,755.5$ & $3,042.2$ & $3,228.9$ & $4,091.4$ & $5,255.4$ \\
\hline & \multicolumn{6}{|c|}{ (Annual change in percent of beginning-of-period broad money) } \\
\hline Broad money & 13.1 & 14.1 & 10.4 & 5.9 & 25.1 & 26.8 \\
\hline Net foreign assets & -45.5 & -27.5 & 2.2 & -1.5 & 33.5 & 50.1 \\
\hline Domestic credit & 58.8 & 34.5 & 27.8 & 10.3 & -3.4 & -20.6 \\
\hline Central government (net) & 42.1 & 13.1 & 4.8 & -5.4 & -25.2 & -39.9 \\
\hline Private sector & 16.7 & 21.4 & 23.0 & 15.7 & 21.8 & 19.3 \\
\hline Other items (net) & -0.1 & 7.1 & -19.6 & -3.0 & -5.0 & -2.7 \\
\hline \multicolumn{7}{|l|}{ Memorandum items: } \\
\hline Currency/broad money (percent) & 6.0 & 7.2 & 7.2 & 7.0 & 5.8 & 4.5 \\
\hline Reserve money/deposits (percent) & 13.5 & 15.6 & 15.7 & 15.2 & 13.8 & 13.8 \\
\hline Money multiplier (broad money/reserve money) & 7.9 & 6.9 & 6.9 & 7.1 & 7.7 & 7.6 \\
\hline Velocity (GDP/period average broad money) & 5.1 & 4.9 & 4.9 & 4.5 & 4.4 & 4.2 \\
\hline
\end{tabular}

Sources: Central Bank of Swaziland (CBS); and Fund staff estimates.

${ }^{1}$ End-of-year data.

${ }^{2}$ Beginning in end-2006, includes government holdings abroad.

${ }^{3}$ Excludes rand in circulation. 
Table 21. Swaziland: Assets and Liabilities of the Central Bank of Swaziland, 2002-07

(In millions of emalangeni, end of period)

\begin{tabular}{|c|c|c|c|c|c|c|}
\hline & 2002 & 2003 & 2004 & 2005 & 2006 & $\begin{array}{r}2007 \\
\text { Oct. }\end{array}$ \\
\hline Foreign assets & 2,472 & 1,758 & 1,474 & 1,536 & 2,405 & 4,284 \\
\hline $\mathrm{CBS}_{\text {managed }}{ }^{1}$ & 2,462 & 1,732 & 1,267 & 1,536 & 2,370 & 3,587 \\
\hline Government & 10 & 27 & 207 & 0 & 35 & 698 \\
\hline Claims on government & 57 & 83 & 252 & 101 & 55 & 22 \\
\hline Claims on private sector & 13 & 12 & 10 & 9 & 20 & 8 \\
\hline Claims on commercial banks & 0 & 0 & 0 & 2 & 314 & 276 \\
\hline Assets $=$ liabilities & 2,543 & 1,853 & 1,736 & 1,648 & 2,795 & 4,591 \\
\hline Foreign liabilities & 371 & 355 & 25 & 18 & 113 & 62 \\
\hline Government deposits $^{2}$ & 1,347 & 1,087 & 978 & 1,183 & 2,015 & 3,612 \\
\hline Of which: holdings abroad & 1,220 & 713 & 667 & 0 & 39 & 701 \\
\hline Private sector deposits & 90 & 92 & 96 & 8 & 3 & 1 \\
\hline Commercial banks & 0 & 0 & 0 & 0 & 0 & 0 \\
\hline Reserve money & 329 & 430 & 477 & 490 & 566 & 725 \\
\hline Currency in circulation ${ }^{3}$ & 227 & 286 & 302 & 341 & 379 & 344 \\
\hline Commercial bank deposits & 102 & 145 & 175 & 149 & 188 & 381 \\
\hline Other items (net) ${ }^{4}$ & 406 & -111 & 159 & -50 & 98 & 191 \\
\hline
\end{tabular}

Source: Central Bank of Swaziland (CBS).

${ }^{1}$ Includes Capital Investment Fund, until 2005.

${ }^{2}$ Includes counterpart of government foreign assets.

${ }^{3}$ Excludes rand in circulation.

${ }^{4}$ Includes balances held with other banks in Swaziland, bills payable, unclassified assets, and unclassified liabilities. 
Table 22. Swaziland: Assets and Liabilities of Commercial Banks, 2002-07 ${ }^{1}$ (In millions of emalangeni, end of period)

\begin{tabular}{|c|c|c|c|c|c|c|}
\hline & 2002 & 2003 & 2004 & 2005 & 2006 & $\begin{array}{r}2007 \\
\text { Oct }\end{array}$ \\
\hline Foreign assets & 791 & 521 & 531 & 443 & 419 & 883 \\
\hline Claims on government & 215 & 287 & 332 & 315 & 309 & 363 \\
\hline Claims on private sector & 1,770 & 2,328 & 3,013 & 3,531 & 3,635 & 3,750 \\
\hline Reserves & 209 & 236 & 256 & 211 & 211 & 347 \\
\hline Balances with CBS & 104 & 121 & 146 & 111 & 111 & 225 \\
\hline Cash in tills ${ }^{2}$ & 72 & 72 & 66 & 99 & 99 & 123 \\
\hline CBS bills & 25 & 0 & 0 & 0 & 0 & 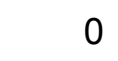 \\
\hline Other items (net) ${ }^{3}$ & -174 & -168 & -103 & 587 & 1,109 & 1,673 \\
\hline Assets $=$ liabilities & 2,812 & 3,204 & 4,030 & 5,087 & 5,683 & 7,017 \\
\hline Foreign liabilities & 76 & 52 & 41 & 69 & 124 & 50 \\
\hline Government deposits & 0 & 0 & 2 & 13 & 64 & 165 \\
\hline Private sector deposits & 2,357 & 2,664 & 2,946 & 3,898 & 4,088 & 5,254 \\
\hline Demand & 670 & 834 & 844 & 1,046 & 1,106 & 1,387 \\
\hline Time & 1,255 & 1,353 & 1,517 & 2,175 & 2,982 & 3,867 \\
\hline Savings & 431 & 476 & 585 & 677 & 0 & 0 \\
\hline Balances due to CBS & 0 & 0 & 34 & 0 & 20 & \\
\hline Capital accounts & 378 & 488 & 1,007 & 1,106 & 1,387 & 1,548 \\
\hline
\end{tabular}

Source: Central Bank of Swaziland (CBS).

1 Includes the Swaziland Development and Savings Bank.

${ }^{2}$ Excludes rand in circulation.

${ }^{3}$ Includes balances held with other banks in Swaziland, bills payable, unclassified assets, and unclassified liabilities. 
Table 23. Swaziland: Commercial Banks' Deposits by Sector, 2002-0 ${ }^{1}$ (In millions of emalangeni, end of period)

\begin{tabular}{|c|c|c|c|c|c|c|}
\hline & 2002 & 2003 & 2004 & $\begin{array}{r}2005 \\
\text { Dec } \\
\end{array}$ & $\begin{array}{r}2006 \\
\text { Dec }\end{array}$ & $\begin{array}{r}2007 \\
\text { Oct } \\
\end{array}$ \\
\hline Demand deposits & 670 & 834 & 845 & 1055 & 1110 & 1321 \\
\hline Central government & 3 & 3 & 1 & 6 & 1 & 5 \\
\hline Other public bodies ${ }^{2}$ & 50 & 49 & 23 & 63 & 37 & 59 \\
\hline Personal & 201 & 264 & 201 & 235 & 172 & 239 \\
\hline Business & 416 & 517 & 620 & 751 & 900 & 1018 \\
\hline Savings deposits & 432 & 477 & 586 & 679 & 699 & 750 \\
\hline Central government & 0 & 0 & 0 & 0 & 0 & 0 \\
\hline Other public bodies ${ }^{2}$ & 2 & 2 & 0 & 0 & 0 & 0 \\
\hline Personal & 403 & 436 & 492 & 646 & 447 & 483 \\
\hline Business & 27 & 38 & 94 & 33 & 252 & 266 \\
\hline Time deposits & 1,255 & 1,353 & 1,517 & 1,498 & 1,783 & 2,193 \\
\hline Central government & 0 & 0 & 0 & 7 & 9 & 19 \\
\hline Other public bodies ${ }^{2 /}$ & 245 & 291 & 106 & 351 & 237 & 295 \\
\hline Personal & 233 & 264 & 230 & 250 & 193 & 184 \\
\hline Business & 777 & 798 & 1182 & 890 & 1345 & 1695 \\
\hline Total deposits & 2,357 & 2,663 & 2,948 & 3,233 & 3,593 & 4,264 \\
\hline Central government & 0 & 0 & 2 & 13 & 10 & 25 \\
\hline Other public bodies ${ }^{2}$ & 297 & 342 & 129 & 415 & 274 & 355 \\
\hline Personal & 837 & 964 & 922 & 1,131 & 813 & 906 \\
\hline Business & 1,220 & 1,353 & 1,896 & 1,674 & 2,496 & 2,979 \\
\hline
\end{tabular}

Source: Central Bank of Swaziland (CBS).

${ }^{1}$ Excluding bank checks outstanding.

${ }^{2}$ Comprises local government, city councils, and statutory corporations. 
Table 24. Swaziland: Commercial Banks' Liquidity Position, 2002-07

(In millions of emalangeni, end of period)

\begin{tabular}{|c|c|c|c|c|c|c|}
\hline & 2002 & 2003 & 2004 & 2005 & 2006 & $\begin{array}{r}2007 \\
\text { Sep }\end{array}$ \\
\hline Total liquid assets ${ }^{1}$ & 495 & 508 & 561 & 549 & 741 & 834 \\
\hline Of which: balance with CBS & 104 & 121 & 146 & 111 & 225 & 207 \\
\hline Required liquid assets & 383 & 371 & 415 & 446 & 529 & 619 \\
\hline Domestic liquidity surplus & 112 & 137 & 146 & 102 & 212 & 214 \\
\hline Net due from foreign banks & 695 & 397 & 394 & 291 & 715 & 444 \\
\hline Total liquidity surplus & 807 & 533 & 540 & 393 & 927 & 658 \\
\hline \multicolumn{7}{|l|}{ Memorandum items: } \\
\hline \multicolumn{7}{|l|}{ Liquidity ratios (in percent) } \\
\hline Required liquidity to deposits & 14 & 13 & 13 & 13 & 13 & 13 \\
\hline Actual liquidity to deposits & 18 & 17 & 17 & 15 & 18 & 15 \\
\hline
\end{tabular}

Source: Central Bank of Swaziland (CBS).

${ }^{1}$ Comprises cash in tills, treasury bills and eligible stock issued by the Swazi government, balances with the CBS and other banks, and other approved liquid assets. Also including rand notes and coins held by banks. 
Table 25. Swaziland: Commercial Bank Loans and Advances by Category of Borrower, 2002-07 (In millions of emalangeni, end of period)

\begin{tabular}{lrrrrrr}
\hline & 2002 & 2003 & 2004 & 2005 & 2006 & $\begin{array}{r}2007 \\
\text { Sep }\end{array}$ \\
\hline Industry & & & & & & \\
$\quad$ Agriculture and forestry & 1,224 & 1,578 & 1,877 & 2,465 & 2,367 & 2,801 \\
$\quad$ Mining and quarrying & 304 & 365 & 403 & 598.4 & 273 & 376 \\
Manufacturing & 6 & 7 & 0 & 1 & 0 & 0 \\
Construction & 311 & 486 & 428 & 393.2 & 291 & 311 \\
Distribution and tourism & 83 & 118 & 136 & 201.3 & 252 & 202 \\
Transport and communications & 163 & 178 & 307 & 379.6 & 457 & 609 \\
Social and personal services & 82 & 115 & 196 & 205.2 & 177 & 223 \\
Other & 141 & 138 & 137 & 140.1 & 140 & 140 \\
& 133 & 171 & 269 & 546.7 & 777 & 939 \\
Personal loans ${ }^{1}$ & & & & & & \\
Statutory bodies & 309 & 530 & 874 & 1,030 & 1,294 & 1583 \\
Other ${ }^{2}$ & 50 & 38 & 70 & 70.1 & 50 & 71 \\
& 70 & 91 & 10 & 17 & 23 & 25 \\
Total & 1,653 & 2,237 & 2,830 & 3,582 & 3,733 & 4,480 \\
\hline
\end{tabular}

Source: Central Bank of Swaziland (CBS).

${ }^{1}$ Includes small amounts lent to nonresidents.

${ }^{2}$ Local authorities and private financial institutions. 
Table 26. Interest Rates in Swaziland and South Africa, Dec. 2002-07

(In percent)

\begin{tabular}{|c|c|c|c|c|c|c|c|}
\hline & 2002 & 2003 & 2004 & 2005 & 2006 & $\begin{array}{r}2007 \\
\text { Aug } \\
\end{array}$ & $\begin{array}{r}2007 \\
\text { Oct } \\
\end{array}$ \\
\hline \multicolumn{8}{|l|}{ Discount rates } \\
\hline Central Bank of Swaziland & 13.5 & 8.0 & 7.5 & 7.00 & 9.00 & 10.00 & 10.50 \\
\hline South African Reserve Bank & 13.5 & 8.0 & 7.5 & 7.00 & 9.00 & 10.00 & 10.50 \\
\hline \multicolumn{8}{|l|}{ Treasury bills } \\
\hline Swaziland & 10.5 & 7.9 & 7.6 & 6.90 & 8.50 & 9.20 & 9.86 \\
\hline South Africa & 12.4 & 7.5 & 7.5 & 9.80 & 8.50 & 9.30 & 9.96 \\
\hline \multicolumn{8}{|l|}{ Prime lending rate } \\
\hline Swaziland & 16.5 & 11.5 & 11.0 & 10.50 & 12.50 & 13.50 & 14.00 \\
\hline South Africa & 17.0 & 11.5 & 11.0 & 10.50 & 12.50 & 13.50 & 14.00 \\
\hline \multicolumn{8}{|l|}{ Bank time deposits } \\
\hline Swaziland-3I days & 8.4 & 4.4 & 3.9 & 3.40 & 5.41 & 6.30 & 6.94 \\
\hline South Africa-3l days & 12.8 & 7.4 & 7.2 & 6.80 & 8.90 & 10.10 & 10.30 \\
\hline Swaziland-I2 months & 9.5 & 4.2 & 4.1 & 3.50 & 8.50 & 9.40 & 9.88 \\
\hline South Africa-I2 months & 12.9 & 7.9 & 7.3 & 7.30 & 9.60 & 10.98 & 11.01 \\
\hline \multicolumn{8}{|l|}{ Bank savings deposits, } \\
\hline Swaziland ${ }^{1}$ & $6.8-9.8$ & $1.0-6.5$ & $0.0-6.5$ & $0.0-6.5$ & $0.0-6.9$ & $0.0-8.78$ & $0.0-9.91$ \\
\hline
\end{tabular}

Source: Central Bank of Swaziland (CBS).

${ }^{1}$ Simple average of end-of-period minimum and maximum rates across banks: rates on large-scale interbank deposits, as well as other money rates, often diverge widely from the deposit rates offered to the general public in Swaziland. 
Table 27. Swaziland: Balance of Payments, 2002-06 ${ }^{1}$

(Millions of U.S. dollars, unless otherwise specified)

\begin{tabular}{|c|c|c|c|c|c|}
\hline & 2002 & 2003 & 2004 & 2005 & $\begin{array}{r}2006 \\
\text { Est. }\end{array}$ \\
\hline Current account balance & 58.0 & 124.2 & 51.7 & -81.4 & -80.8 \\
\hline Trade balance & 90.7 & 103.8 & 91.0 & -121.8 & -140.4 \\
\hline Exports, f.o.b. & $1,031.6$ & $1,387.1$ & $1,808.9$ & $1,612.5$ & $1,484.4$ \\
\hline Imports, f.o.b. & -940.8 & $-1,283.2$ & $-1,717.9$ & $-1,734.3$ & $-1,624.8$ \\
\hline Services (net) & -93.9 & -66.7 & -152.6 & -111.2 & -71.7 \\
\hline Exports of services & 102.2 & 193.1 & 250.0 & 284.3 & 283.1 \\
\hline Imports of services & -196.1 & -259.9 & -402.6 & -395.5 & -354.8 \\
\hline Goods and services balance & -3.2 & 37.1 & -61.6 & -233.0 & -212.1 \\
\hline Income (net) & -1.9 & 40.8 & 7.4 & 58.2 & 0.6 \\
\hline Income (credits) & 144.2 & 143.5 & 132.5 & 158.4 & 166.9 \\
\hline Income (debits) & -146.1 & -102.8 & -125.1 & -100.2 & -166.3 \\
\hline Of which: interest & -15.9 & -18.1 & -21.2 & -20.1 & -21.8 \\
\hline Transfers (net) & 63.1 & 46.3 & 106.0 & 93.3 & 132.5 \\
\hline Official sector (mainly SACU receipts) ${ }^{2}$ & 100.5 & 333.3 & 371.4 & 331.0 & 377.8 \\
\hline Private sector & -37.4 & -287.0 & -265.4 & -237.7 & -245.4 \\
\hline Capital and financial account balance & -52.6 & 114.7 & -206.6 & 85.3 & 143.0 \\
\hline Capital account balance & 0.5 & 0.0 & -0.6 & -3.5 & 24.7 \\
\hline Financial account balance (excluding reserve assets) & -53.1 & 114.7 & -206.0 & 88.8 & 118.3 \\
\hline Direct investment & 90.2 & 70.7 & 66.4 & 50.2 & 32.6 \\
\hline Portfolio investment & 1.9 & -0.4 & -11.3 & 0.6 & -0.2 \\
\hline Other investment & -145.2 & 44.4 & -261.2 & 38.0 & 85.8 \\
\hline Errors and omissions & -99.5 & -161.6 & 141.4 & -21.3 & 75.1 \\
\hline Overall balance & -94.1 & 77.3 & -13.5 & -17.4 & 137.3 \\
\hline \multicolumn{6}{|l|}{ Memorandum items: } \\
\hline Current account/GDP (percent) & 4.9 & 6.8 & 2.2 & -3.1 & -2.9 \\
\hline Goods and services balance/GDP (percent) & -0.3 & 2.0 & -2.6 & -8.9 & -7.7 \\
\hline Gross official reserves (end of period) & 259.5 & 264.8 & 261.8 & 230.9 & 364.4 \\
\hline In months of imports of goods and services & 2.7 & 2.1 & 1.5 & 1.3 & 2.2 \\
\hline Lilangeni per U.S. dollar (end of period) & 8.64 & 6.64 & 5.63 & 6.33 & 6.96 \\
\hline Lilangeni per U.S. dollar (period average) & 10.52 & 7.56 & 6.45 & 6.36 & 6.80 \\
\hline Exports fob, volume growth & 19.7 & 0.6 & 34.4 & -15.4 & -4.0 \\
\hline Imports fob, volume growth & -5.5 & -15.4 & -1.9 & -1.4 & -1.7 \\
\hline
\end{tabular}

Sources: Central Bank of Swaziland; and IMF staff projections.

${ }^{1}$ Without corrective policy measures.

${ }^{2}$ SACU: Southern African Customs Union. SACU transfers in the current account does not reflect the true level of SACU revenue because of the particular treatment of those transfers in the accounts where the authorities make an estimate based on the level of imports and adjust in 'other investment' to reflect the total SACU revenues. 
Table 28. Swaziland: Balance of Payments, 2002-06 ${ }^{1}$

(Millions of U.S. dollars, unless otherwise specified)

\begin{tabular}{|c|c|c|c|c|c|}
\hline & 2002 & 2003 & 2004 & 2005 & $\begin{array}{r}2006 \\
\text { Est. }\end{array}$ \\
\hline Current account balance & 610.3 & 939.7 & 333.7 & -517.4 & -549.2 \\
\hline Trade balance & 954.0 & 785.4 & 587.0 & -774.8 & -954.9 \\
\hline Exports, f.o.b. & $10,848.3$ & $10,492.8$ & $11,667.3$ & $10,254.1$ & $10,094.0$ \\
\hline Imports, f.o.b. & $-9,894.3$ & $-9,707.4$ & $-11,080.3$ & $-11,028.9$ & $-11,048.9$ \\
\hline Services (net) & -987.4 & -504.6 & -984.3 & -707.0 & -487.5 \\
\hline Exports of services & $1,074.7$ & $1,461.1$ & $1,612.5$ & $1,807.9$ & $1,925.1$ \\
\hline Imports of services & $-2,062.1$ & $-1,965.7$ & $-2,596.8$ & $-2,514.9$ & $-2,412.6$ \\
\hline Goods and services balance & -33.4 & 280.8 & -397.3 & $-1,481.8$ & $-1,442.4$ \\
\hline Income (net) & -19.9 & 308.3 & 47.5 & 370.0 & 4.4 \\
\hline Income (credits) & $1,516.7$ & $1,085.7$ & 854.5 & $1,007.3$ & $1,135.1$ \\
\hline Income (debits) & $-1,536.6$ & -777.4 & -807.0 & -637.3 & $-1,130.7$ \\
\hline Of which: interest & -167.0 & -137.1 & -136.6 & -127.9 & -148.4 \\
\hline Transfers (net) & 663.6 & 350.6 & 683.5 & 593.4 & 900.8 \\
\hline Official sector (mainly SACU receipts) ${ }^{2}$ & $1,056.9$ & $2,521.4$ & $2,395.6$ & $2,105.0$ & $2,569.2$ \\
\hline Private sector & -393.3 & $-2,170.8$ & $-1,712.1$ & $-1,511.6$ & $-1,668.4$ \\
\hline Capital and financial account balance & -553.4 & 867.3 & $-1,332.5$ & 542.5 & 972.2 \\
\hline Capital account balance & 4.9 & 0.0 & -3.7 & -22.2 & 167.8 \\
\hline Financial account balance (excluding reserve assets) & -558.3 & 867.3 & $-1,328.8$ & 564.7 & 804.4 \\
\hline Direct investment & 948.6 & 534.5 & 428.2 & 319.1 & 221.8 \\
\hline Portfolio investment & 20.0 & -3.1 & -72.6 & 3.8 & -1.1 \\
\hline Other investment & $-1,526.9$ & 335.9 & $-1,684.4$ & 241.8 & 583.7 \\
\hline Errors and omissions & $-1,046.5$ & $-1,222.5$ & 911.7 & -135.7 & 510.5 \\
\hline Overall balance & -989.6 & 584.5 & -87.1 & -110.6 & 933.5 \\
\hline \multicolumn{6}{|l|}{ Memorandum items: } \\
\hline Current account/GDP (percent) & 4.9 & 6.8 & 2.2 & -3.1 & -2.9 \\
\hline Goods and services balance/GDP (percent) & -0.3 & 2.0 & -2.6 & -8.9 & -7.7 \\
\hline Gross official reserves (end of period) & $2,729.5$ & $2,003.2$ & $1,688.9$ & $1,468.3$ & $2,478.2$ \\
\hline In months of imports of goods and services & 2.7 & 2.1 & 1.5 & 1.3 & 2.2 \\
\hline Lilangeni per U.S. dollar (end of period) & 8.64 & 6.64 & 5.63 & 6.33 & 6.96 \\
\hline Lilangeni per U.S. dollar (period average) & 10.52 & 7.56 & 6.45 & 6.36 & 6.80 \\
\hline Exports fob, volume growth & 19.7 & 0.6 & 34.4 & -15.4 & -4.0 \\
\hline Imports fob, volume growth & -5.5 & -15.4 & -1.9 & -1.4 & -1.7 \\
\hline
\end{tabular}

Sources: Central Bank of Swaziland; and IMF staff projections.

${ }^{1}$ Without corrective policy measures.

${ }^{2}$ SACU: Southern African Customs Union. SACU transfers in the current account does not reflect the true level of SACU revenue because of the particular treatment of those transfers in the accounts where the authorities make an estimate based on the level of imports and adjust in 'other investment' to reflect the total SACU revenues. 
Table 29. Swaziland: Merchandise Exports, 2000-04

(In millions of U.S. dollars)

\begin{tabular}{|c|c|c|c|c|c|}
\hline & 2000 & 2001 & 2002 & 2003 & 2004 \\
\hline Sugar & 97 & 76 & 64 & 118 & 123.7 \\
\hline Wood pulp & 65 & 61 & 69 & 178 & 81.4 \\
\hline Asbestos & 3 & 1 & 0 & 0 & 0.0 \\
\hline Meat and meat products & 3 & 0 & 3 & 0 & 4.2 \\
\hline Canned fruit & 13 & 10 & 15 & 11 & 28.5 \\
\hline Citrus & 1 & 10 & 6 & 28 & 3.0 \\
\hline Coal & 7 & 2 & 6 & 25 & 6.7 \\
\hline Diamond & 0 & 0 & 0 & 0 & 0.0 \\
\hline Zippers & 13 & 12 & 10 & 20 & 24.8 \\
\hline Edible concentrates & 204 & 281 & 276 & 762 & 638.9 \\
\hline Wood and wood products & 22 & 19 & 17 & 0 & 14.4 \\
\hline Cottonseed and lint & 4 & 5 & 0 & 220 & 0.0 \\
\hline Chemicals & 0 & 0 & 0 & 0 & 0.1 \\
\hline Automobile & 0 & 0 & 0 & 0 & 0.0 \\
\hline Fruit squash & 14 & 9 & 6 & 20 & 11.2 \\
\hline Brake linings & 0 & 0 & 0 & 1 & 0.0 \\
\hline Cotton yarn & 16 & 10 & 14 & 0 & 18.7 \\
\hline Face bricks & 0 & 0 & 0 & 0 & 0.7 \\
\hline Footwear & 0 & 0 & 0 & 1 & 0.0 \\
\hline Other textiles & 18 & 50 & 149 & 0 & 248.9 \\
\hline Paper products & 18 & 8 & 8 & 26 & 6.2 \\
\hline Plastic products & 2 & 0 & 0 & 37 & 1.9 \\
\hline Refrigerators & 62 & 2 & 1 & 5 & 18.4 \\
\hline Ethanol & 3 & 0 & 9 & 0 & 6.2 \\
\hline Eucalyptus & 4 & 18 & 3 & 0 & 1.7 \\
\hline Television sets & 0 & 0 & 0 & 10 & 0.0 \\
\hline Windscreens & 0 & 0 & 0 & 1 & 0.0 \\
\hline Other food products & 35 & 23 & 37 & 0 & 51.1 \\
\hline Other/errors and omissions & 399 & 428 & 477 & 246 & 289.6 \\
\hline Total domestic exports & 1,002 & 1,026 & 1,170 & 1,709 & 1,580 \\
\hline Reexports & 41 & 5 & 217 & 100 & 32 \\
\hline Total exports, f.o.b. & 1,043 & 1,032 & 1,387 & 1,809 & 1,612 \\
\hline
\end{tabular}

Sources: Central Statistical Office; and Central Bank of Swaziland. 
Table 30. Swaziland: Sugar Exports by Volume, Value, and Unit Price, 2001-05

\begin{tabular}{|c|c|c|c|c|c|}
\hline & 2001 & 2002 & 2003 & 2004 & 2005 \\
\hline & \multicolumn{5}{|c|}{ (In thousands of metric tons) } \\
\hline \multicolumn{6}{|l|}{ Volume } \\
\hline Non-SACU & 273 & 281 & 279 & 296 & 320 \\
\hline European Union (EU) & 169 & 153 & 147 & 158 & 152 \\
\hline United States & 16 & 16 & 16 & 16 & 28 \\
\hline Other & 88 & 112 & 116 & 122 & 140 \\
\hline SACU ${ }^{1}$ & 296 & 281 & 332 & 311 & 314 \\
\hline Total production ${ }^{2}$ & 501 & 583 & 628 & 598 & 649 \\
\hline & \multicolumn{5}{|c|}{ (In millions of emalangeni) } \\
\hline \multicolumn{6}{|c|}{ 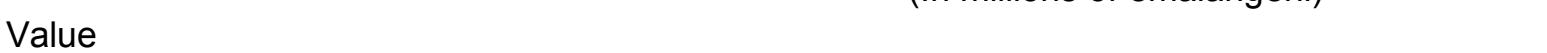 } \\
\hline Non-SACU & 662 & 956 & 787 & 745 & 831 \\
\hline EU & 498 & 731 & 596 & 576 & 559 \\
\hline United States & 50 & 68 & 44 & 34 & 64 \\
\hline Other & 114 & 157 & 147 & 135 & 208 \\
\hline SACU ${ }^{1}$ & 701 & 743 & 874 & 801 & 842 \\
\hline & \multicolumn{5}{|c|}{ (In U.S. dollars per metric ton) } \\
\hline \multicolumn{6}{|l|}{ Average unit price } \\
\hline Non-SACU & 282 & 324 & 373 & 390 & 399 \\
\hline EU & 343 & 454 & 536 & 567 & 565 \\
\hline United States & 363 & 404 & 364 & 329 & 351 \\
\hline Other & 151 & 133 & 168 & 172 & 228 \\
\hline $\mathrm{SACU}^{1}$ & 275 & 251 & 348 & 399 & 412 \\
\hline & \multicolumn{5}{|c|}{ (In emalangeni per metric ton) } \\
\hline \multicolumn{6}{|l|}{ Average unit price } \\
\hline Non-SACU & 2,425 & 3,402 & 2,821 & 2,517 & 2,597 \\
\hline EU & 2,947 & 4,778 & 4,054 & 3,657 & 3,678 \\
\hline United States & 3,125 & 4,250 & 2,750 & 2,125 & 2,286 \\
\hline Other & 1,295 & 1,402 & 1,267 & 1,107 & 1,486 \\
\hline SACU ${ }^{1}$ & 2,368 & 2,644 & 2,633 & 2,576 & 2,682 \\
\hline
\end{tabular}

Source: Swaziland Sugar Association.

${ }^{1}$ The Southern African Customs Union (SACU) accounts for all sales to SACU countries and includes sales of sugar within Swaziland (normally about 10-15 percent of SACU sales).

${ }^{2}$ The difference between total production and total exports represents a change in stock. 
Table 31. Swaziland: Other Principal Exports by Volume, Value, and Unit Price, 2000-04

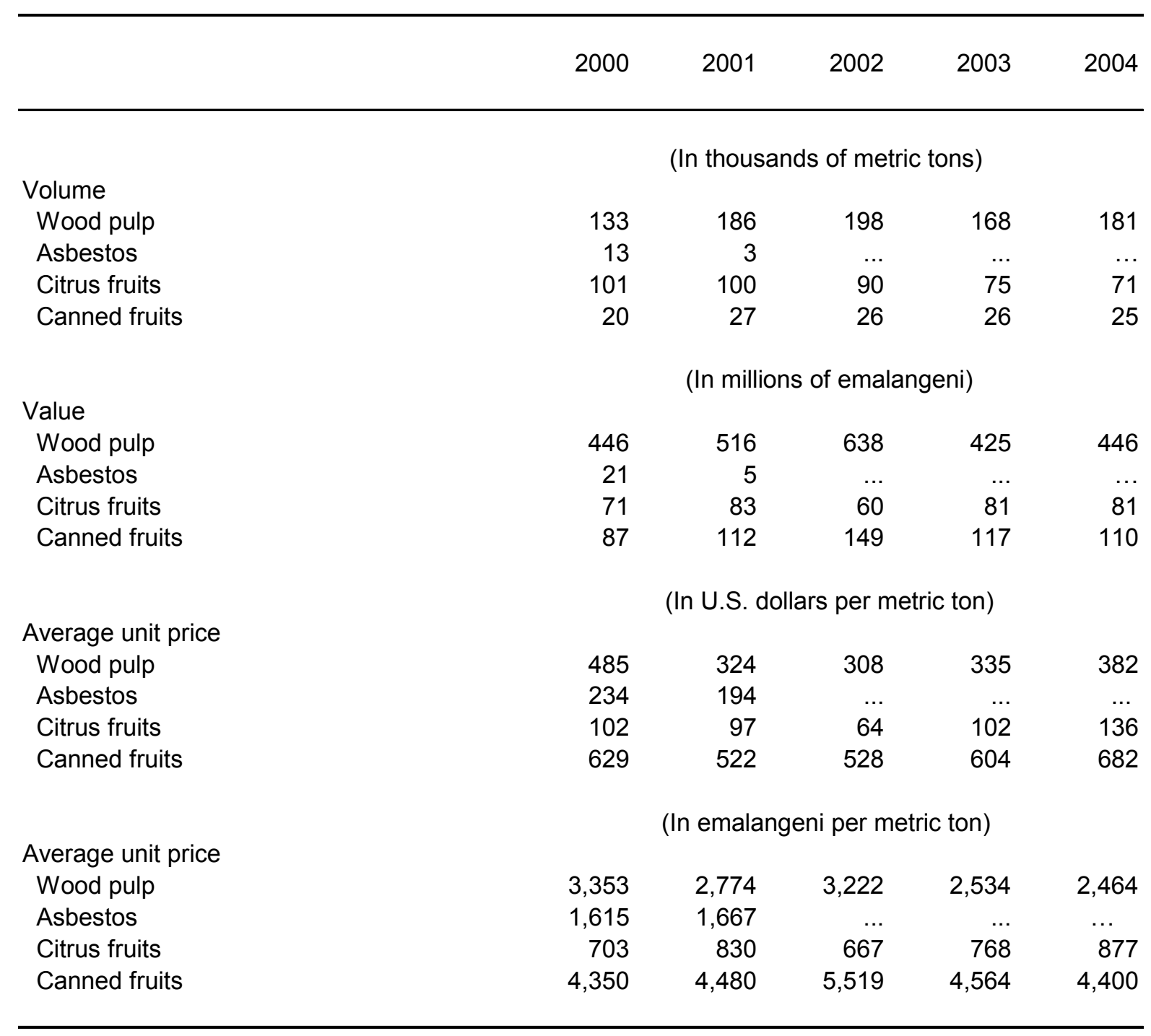

Source: Central Bank of Swaziland. 
Table 32. Swaziland: Merchandise Imports, 2001-06

(In millions of U.S. dollars, unless otherwise indicated)

\begin{tabular}{lrrrrr}
\hline & 2001 & 2002 & 2004 & 2005 & 2006 \\
& & & & & \\
\hline & & & & & \\
Food and live animals & 142 & 143 & 176 & 237 & 239 \\
Beverages and tobacco & 22 & 20 & 41 & 54 & 55 \\
Inedible crude materials & 35 & 29 & 43 & 58 & 58 \\
Minerals, fuels, and lubricants & 168 & 123 & 133 & 191 & 206 \\
Animal and vegetable oils and fat & 11 & 10 & 19 & 26 & 26 \\
Chemicals and chemical products & 204 & 113 & 171 & 230 & 233 \\
Manufactures classified by material & 159 & 159 & 249 & 335 & 338 \\
Machinery and transport equipment & 212 & 220 & 316 & 424 & 428 \\
Miscellaneous manufactures & 145 & 99 & 128 & 172 & 174 \\
Commodities not classified by kind & 113 & 108 & 111 & 150 & 138 \\
& & & & & \\
Total imports, c.i.f. & 1,210 & 1,023 & 1,387 & 1,877 & 1,895 \\
Total imports, f.o.b. & 1,125 & 941 & 1,283 & 1,718 & 1,734 \\
& & & & & \\
\hline
\end{tabular}

Source: Central Bank of Swaziland. 
Table 33: Swaziland: Services and Income Account, 2001-05

(In millions of U.S. dollars)

\begin{tabular}{|c|c|c|c|c|c|}
\hline & 2001 & 2002 & 2003 & 2004 & 2005 \\
\hline Nonfactor services: credit & 113.8 & 102.2 & 193.1 & 250.0 & 284.3 \\
\hline Swaziland Railways & 8.2 & 7.8 & 15.5 & 6.6 & 11.4 \\
\hline Other shipment and transportation & 4.9 & 10.4 & 26.6 & 13.5 & 16.9 \\
\hline Travel & 30.5 & 60.1 & 124.7 & 64.0 & 69.9 \\
\hline Other official & 2.1 & 4.8 & 8.6 & 6.6 & 10.1 \\
\hline Other Private & 68.1 & 19.1 & 17.8 & 159.3 & 176.0 \\
\hline Nonfactor services: debit & -225.6 & -196.1 & -259.9 & -402.6 & -395.5 \\
\hline Shipment and tansp. & -51.7 & -46.5 & -97.3 & -66.9 & -92.9 \\
\hline Travel & -57.5 & -54.1 & -7.3 & 4.2 & -20.5 \\
\hline Other official & -19.8 & -10.8 & -15.2 & -9.5 & -28.7 \\
\hline Other Private & -96.5 & -84.7 & -140.1 & -330.4 & -253.3 \\
\hline Factor income: credit & 156.7 & 144.2 & 143.5 & 132.5 & 158.4 \\
\hline Investment income & 83.1 & 82.9 & 59.5 & 44.2 & 67.5 \\
\hline Official & 81.8 & 79.4 & 57.3 & 41.1 & 66.3 \\
\hline Private (incl. Property income) & 1.3 & 3.6 & 2.2 & 3.1 & 1.2 \\
\hline Labour income & 73.6 & 61.3 & 84.0 & 88.3 & 91.0 \\
\hline Factor income: debit & -54.4 & -146.1 & -102.8 & -125.1 & -100.2 \\
\hline Investment income & -30.4 & -105.3 & -58.4 & -61.8 & -49.0 \\
\hline Official \& Govnt. guaranteed & -15.4 & -15.9 & -18.1 & -21.2 & -20.1 \\
\hline Private & -15.0 & -89.4 & -40.3 & -40.6 & -28.9 \\
\hline Property income & -24.0 & -40.9 & -41.9 & -59.9 & -48.5 \\
\hline Labour income & 0.0 & 0.0 & -4.4 & -7.0 & -5.5 \\
\hline Services and income: credit & 270.5 & 246.4 & 336.7 & 382.5 & 442.7 \\
\hline Services and income: debit & -280.0 & -342.2 & -362.6 & -527.7 & -495.7 \\
\hline Services (net) & -111.8 & -93.9 & -66.7 & -152.6 & -111.2 \\
\hline Factor income (net) & 102.3 & -1.9 & 40.8 & 7.4 & 58.2 \\
\hline Total (net) & -9.5 & -95.8 & -25.9 & -145.2 & -53.0 \\
\hline
\end{tabular}

Source: Central Bank of Swaziland 
Table 34. Swaziland: Financial Account, 2002-06

(In millions of U.S. dollars)

\begin{tabular}{|c|c|c|c|c|c|}
\hline & 2002 & 2003 & 2004 & 2005 & 2006 \\
\hline Direct investment (net) & 90.2 & 70.7 & 66.4 & 50.2 & 32.6 \\
\hline Direct investment in Swaziland & 89.5 & 60.9 & 64.9 & 28.1 & 36.2 \\
\hline Equity capital & -10.1 & -3.8 & -4.8 & -4.0 & 2.0 \\
\hline Reinvestment of earnings & 65.3 & 11.2 & 34.5 & 20.8 & 25.6 \\
\hline Other long-term capital & -19.1 & 15.9 & 19.4 & 1.4 & 3.2 \\
\hline Other short-term capital & 52.4 & 37.6 & 15.8 & 9.9 & 5.4 \\
\hline Direct investment abroad & 0.7 & 9.8 & 1.4 & 22.0 & -3.6 \\
\hline Equity capital & 0.4 & 0.4 & 0.0 & -0.1 & 0.0 \\
\hline Reinvestment of earnings & -2.3 & 0.0 & 0.0 & 0.0 & 0.0 \\
\hline Other long-term capital & 0.1 & 0.3 & 0.0 & -0.7 & 0.0 \\
\hline Other short-term capital & 2.5 & 9.8 & 1.4 & 22.8 & -3.6 \\
\hline Long-term capital (net) & -159.1 & -45.0 & -68.5 & -31.3 & -36.2 \\
\hline Public sector (net) & 6.3 & -2.2 & 6.9 & 26.7 & 23.5 \\
\hline Loan drawings (liability) & 20.5 & 15.2 & 28.3 & 44.1 & 52.1 \\
\hline Loan repayments (liability) & -14.2 & -17.4 & -21.4 & -17.4 & -19.6 \\
\hline Sasol Funds (assets) & 0.0 & 0.0 & 0.0 & 0.0 & 0.0 \\
\hline Private sector (net) & -165.4 & -42.8 & -75.4 & -58.0 & -59.7 \\
\hline Private sector (liability) & -31.2 & -1.1 & 0.3 & 0.3 & 0.5 \\
\hline Corporate equity securities & -2.0 & -0.1 & -0.3 & 0.3 & 0.5 \\
\hline Loans (drawings and repayments) & -29.2 & -1.0 & 0.6 & 0.0 & 0.0 \\
\hline Private sector (assets) & -134.2 & -41.8 & -75.7 & -58.3 & -60.2 \\
\hline Corporate equity securities & 0.0 & 0.0 & 0.2 & 0.0 & 0.0 \\
\hline Debt securities (money markets) & 3.9 & -0.3 & -10.9 & 3.7 & -1.5 \\
\hline Loans (drawings and repayments) & 0.0 & -5.3 & 3.6 & -0.1 & 0.0 \\
\hline Other assets including pension funds & -138.1 & -36.1 & -68.6 & -61.9 & -58.7 \\
\hline Short-term capital (net) & -73.3 & 86.9 & -229.5 & 40.4 & 120.5 \\
\hline Public sector (net) & -23.3 & 97.1 & -203.0 & -2.6 & 85.5 \\
\hline Received under Southern African Customs Union (SACU) (lia & 146.6 & 280.4 & 272.9 & 322.4 & 345.6 \\
\hline Monetary authority currency/deposits (liability) & -9.8 & -2.7 & -50.3 & 0.0 & 0.0 \\
\hline Other liabilities & 0.0 & 0.0 & 0.0 & 0.0 & 0.0 \\
\hline Receivable under SACU & -160.1 & -180.6 & -425.6 & -325.0 & -260.1 \\
\hline Private sector (net) & -50.0 & -10.2 & -26.5 & 43.0 & 35.0 \\
\hline Banks (net) & 14.4 & 32.5 & -3.2 & 22.1 & 11.8 \\
\hline Currency and deposits (assets) & 9.6 & 35.7 & -1.6 & 17.7 & 13.9 \\
\hline Other liabilities (liability) & 4.8 & -3.3 & -1.7 & 4.4 & -2.1 \\
\hline Other (net) & -64.4 & -42.7 & -23.3 & 20.9 & 23.2 \\
\hline Trade credit (liability) & -6.8 & 2.0 & -1.3 & 2.8 & 1.5 \\
\hline Other liabilities (liability) & -6.5 & -12.8 & -0.9 & -1.9 & -2.0 \\
\hline Trade credit (assets) & -13.0 & -50.2 & -2.2 & 5.8 & 7.8 \\
\hline Currency holdings & -38.1 & 18.3 & -18.9 & 14.2 & 15.9 \\
\hline Other (unrecorded) & 89.6 & 2.1 & 25 & 26.0 & 26.0 \\
\hline Financial and capital account balance & -52.6 & 114.6 & -206.6 & 85.3 & 142.9 \\
\hline
\end{tabular}

Source: Central Bank of Swaziland. 
Table 35. Swaziland: Public Sector External Debt, 2002/03-2006/071

(In millions of U.S. dollars)

\begin{tabular}{|c|c|c|c|c|c|}
\hline & $2002 / 03$ & $2003 / 04$ & $2004 / 05$ & $2005 / 06$ & $2006 / 07^{2}$ \\
\hline Multilateral loans & 160.0 & 195.0 & 198.6 & 224.5 & 230.9 \\
\hline IBRD & 9.0 & 16.0 & 21.5 & 21.0 & 21.0 \\
\hline IDA & 4.0 & 4.0 & 3.7 & 3.5 & 3.4 \\
\hline Arab League & 0.0 & 0.0 & 0.0 & 0.0 & 0.0 \\
\hline United Nations & 0.0 & 0.0 & 0.0 & 0.0 & 0.0 \\
\hline African Development Bank/Fund & 123.0 & 142.0 & 130.1 & 158.9 & 168.1 \\
\hline European Development Fund/European Investment Bank & 21.0 & 30.0 & 40.7 & 38.0 & 32.4 \\
\hline IMF Trust Fund & 0.0 & 0.0 & 0.0 & 0.0 & 0.0 \\
\hline International Fund for Agricultural Development & 3.0 & 3.0 & 2.5 & 3.1 & 6.0 \\
\hline Economic Development for Equatorial and Southern Africa & 0.0 & 0.0 & 0.0 & 0.0 & 0.0 \\
\hline Bilateral loans & 104.0 & 171.0 & 112.5 & 91.7 & 89.7 \\
\hline United Kingdom & 1.0 & 1.0 & 0.6 & 0.6 & 0.2 \\
\hline Germany & 11.0 & 29.0 & 22.4 & 20.1 & 19.8 \\
\hline United States & 7.0 & 7.0 & 6.1 & 5.7 & 5.5 \\
\hline Denmark & 6.0 & 6.0 & 6.4 & 4.7 & 4.8 \\
\hline Canada & 0.0 & 0.0 & 0.0 & 0.0 & 0.0 \\
\hline Other & 79.0 & 128.0 & 77.0 & 60.7 & 59.4 \\
\hline Financial institutions & 24.0 & 37.0 & 37.8 & 57.2 & 57.2 \\
\hline Other & 0.0 & 0.0 & 0.0 & 0.0 & 0.0 \\
\hline Total & 289.0 & 403.0 & 348.9 & 373.4 & 377.8 \\
\hline
\end{tabular}

Source: Ministry of Finance.

${ }^{1}$ Fiscal year runs from April 1 to March 31.

${ }^{2}$ Preliminary figures 
Table 36. Swaziland: Public Sector External Debt Service, 2002/03-2006/07 (In millions of emalangeni)

\begin{tabular}{lrrrrr}
\hline & $2002 / 03$ & $2003 / 04$ & $2004 / 05$ & $2005 / 06$ & $2006 / 07^{2}$ \\
& & & & & \\
\hline & 155.0 & 141.0 & 115.0 & 156.0 & 143.9 \\
Multilateral loans & 67.0 & 63.0 & 49.0 & 84.0 & 67.9 \\
$\quad$ Interest & 88.0 & 78.0 & 66.0 & 72.0 & 76.0 \\
$\quad$ Principal & & & & & \\
& 68.0 & 70.0 & 35.0 & 43.0 & 21.5 \\
Bilateral loans & 20.0 & 36.0 & 7.0 & 7.0 & 5.5 \\
$\quad$ Interest & 48.0 & 34.0 & 28.0 & 36.0 & 16.0 \\
$\quad$ Principal & & & & & \\
& 26.0 & 10.0 & 64.0 & 64.0 & 61.8 \\
Financial institutions & 21.0 & 10.0 & 64.0 & 54.0 & 43.0 \\
$\quad$ Interest & 5.0 & 0.0 & 0.0 & 10.0 & 18.7 \\
$\quad$ Principal & & & & & \\
& 249.0 & 221.0 & 214.0 & 263.0 & 227.2 \\
Total & 108.0 & 109.0 & 120.0 & 145.0 & 116.4 \\
$\quad$ Interest & 141.0 & 112.0 & 94.0 & 118.0 & 110.7 \\
$\quad$ Principal & & & & & \\
\hline
\end{tabular}

Source: Ministry of Finance.

${ }^{1}$ Fiscal year runs from April 1 to March 31.

${ }^{2}$ Preliminary figures 
Table 37. Swaziland: Exports and Share of South Africa, 2005

\begin{tabular}{|c|c|c|c|}
\hline & \multicolumn{2}{|c|}{2005} & \multirow{2}{*}{$\begin{array}{l}\text { Share of } \\
\text { Exports to } \\
\text { South Africa } \\
\text { (In percent) }\end{array}$} \\
\hline & $\frac{\text { Total Exports }}{\text { (In thousands }}$ & $\begin{array}{c}\text { Exports to } \\
\text { South Africa } \\
\text { f U.S. dollars) }\end{array}$ & \\
\hline Standard International Trade Classific & & & \\
\hline Food and beverages & 318,532 & 232,072 & 73 \\
\hline Citrus fruit & 26,451 & 16,261 & 61 \\
\hline Canned fruit and fruit juices & 32,822 & 16,176 & 49 \\
\hline Sugar, mainly raw & 259,182 & 199,570 & 77 \\
\hline Nonalcoholic beverages & 76 & 66 & 86 \\
\hline Crude materials & 265,023 & 205,400 & 78 \\
\hline Coke and wood & 66,282 & 66,282 & 100 \\
\hline Pulp and waste paper & 198,741 & 139,118 & 70 \\
\hline Manufactures classified by material & 145,410 & 105,579 & 73 \\
\hline Paper products & 58,445 & 43,833 & 75 \\
\hline Textiles and yarns & 86,965 & 61,745 & 71 \\
\hline Machinery and transport equipment & 16,713 & 12,955 & 78 \\
\hline General industrial machinery & 3,398 & 3,355 & 99 \\
\hline Other machinery and equipment & 13,314 & 9,600 & 72 \\
\hline Miscellaneous manufactured articles & 312,261 & 172,647 & 55 \\
\hline Furniture and parts thereof & 89,060 & 49,873 & 56 \\
\hline Apparel and clothing & 222,253 & 122,239 & 55 \\
\hline Footwear & 949 & 534 & 56 \\
\hline Other & 554,311 & 388,018 & 70 \\
\hline Total, f.o.b. & $1,612,249$ & $1,116,671$ & 69 \\
\hline
\end{tabular}

Source: Central Bank of Swaziland and Department of Customs and Excise, Swaziland. 
Table 38. Swaziland: Main Imports and Share of South Africa, 2005

\begin{tabular}{|c|c|c|c|}
\hline & $\frac{\text { Total Imports }}{\text { (In thousands o }}$ & $\begin{array}{l}\text { Imports from } \\
\text { South Africa } \\
\text { f U.S. dollars) }\end{array}$ & $\begin{array}{c}\text { Share of } \\
\text { Imports from } \\
\text { South Africa } \\
\text { (In percent) }\end{array}$ \\
\hline \multicolumn{4}{|c|}{ Standard International Trade Classification (SITC) } \\
\hline Food and beverages & 229,749 & 215,944 & 95 \\
\hline Live animals & 18,691 & 14,674 & 79 \\
\hline Dairy products & 25,552 & 25,137 & 98 \\
\hline Vegetables & 27,542 & 26,914 & 98 \\
\hline Cereals & 6,998 & 6,700 & 96 \\
\hline Flour, malt, and gluten & 76,015 & 69,481 & 91 \\
\hline Sugar & 451 & 451 & 100 \\
\hline Bread and pasta & 24,156 & 23,214 & 96 \\
\hline Juice and jams & 12,868 & 12,852 & 100 \\
\hline Ice cream, sauces, and soups & 10,385 & 10,340 & 100 \\
\hline Beverages & 27,090 & 26,180 & 97 \\
\hline Chemicals and fuels & 399,338 & 385,749 & 95 \\
\hline Inorganic chemicals & 21,398 & 20,727 & 97 \\
\hline Pharmaceuticals & 21,754 & 19,405 & 89 \\
\hline Fertilizers & 42,319 & 42,078 & 99 \\
\hline Toiletries and perfumes & 8,467 & 8,202 & 97 \\
\hline Soaps, polishes, and wax & 70,405 & 70,175 & 100 \\
\hline Gelatin and adhesives & 198 & 195 & 99 \\
\hline Plastics & 59,208 & 49,242 & 83 \\
\hline Fuels (coal and petroleum) & 175,589 & 175,725 & 100 \\
\hline Manufactures classified by materials & 174,445 & 163,562 & 84 \\
\hline Rubber and products thereof & 20,690 & 20,456 & 99 \\
\hline Wood and products thereof & 47,195 & 47,100 & 100 \\
\hline Paper products & 92,795 & 85,628 & 92 \\
\hline Newspaper, printed & 1,215 & 1,215 & 100 \\
\hline Special woven fabrics & 3,123 & 313 & 10 \\
\hline Iron and steel products & 8,057 & 7,551 & 94 \\
\hline Aluminum products & 1,370 & 1,299 & 95 \\
\hline \multicolumn{4}{|l|}{ Nonmetallic minerals } \\
\hline Machinery, transport equipment, and others & 701,933 & 646,187 & 92 \\
\hline Nonelectric machinery & 324,098 & 284,513 & 88 \\
\hline Electric machinery & 72,957 & 72,515 & 99 \\
\hline Vehicles & 142,407 & 134,608 & 95 \\
\hline Clothing & 117,854 & 110,455 & 94 \\
\hline Footwear & 17,538 & 17,498 & 100 \\
\hline Furniture & 27,080 & 26,598 & 98 \\
\hline Subtotal & $1,505,466$ & $1,411,441$ & 94 \\
\hline Other & 371,527 & 303,393 & 82 \\
\hline Total & $1,876,992$ & $1,714,834$ & 91 \\
\hline
\end{tabular}

Source: Central Bank of Swaziland and Department of Customs and Excise, Swaziland. 
Table 39. Swaziland: Commercial Banks' Performance Ratios, Dec. 2003-07

\begin{tabular}{|c|c|c|c|c|c|}
\hline & $\begin{array}{c}2003 \\
\text { Dec. }\end{array}$ & $\begin{array}{c}2004 \\
\text { Dec. }\end{array}$ & $\begin{array}{r}2005 \\
\mathrm{Dec}\end{array}$ & $\begin{array}{r}2006 \\
\mathrm{Dec} \\
\end{array}$ & $\begin{array}{l}2007 \\
\text { June } \\
\end{array}$ \\
\hline & \multicolumn{4}{|c|}{ (Percent) } & \\
\hline \multicolumn{6}{|l|}{ Performance Ratios } \\
\hline Basle capital ratio (Tier 1 ) & 14 & 14 & 15 & 20 & 23 \\
\hline Basle capital ratio (Tier 2 ) & 20 & 16 & 17 & 26 & 23 \\
\hline \multicolumn{6}{|l|}{ Asset Quality } \\
\hline Loans to deposit ratio ${ }^{1}$ & 75 & 73 & 83 & 86 & 88 \\
\hline Earning assets to total assets & 90 & 87 & 92 & 65 & 67 \\
\hline Nonperforming loans to total loans ${ }^{1}$ & 2 & 3 & 2 & 4 & 4 \\
\hline Reserve for losses to total loans & 9 & 8 & 7 & 10 & 9 \\
\hline \multicolumn{6}{|l|}{ Liquidity Ratios } \\
\hline Liquid assets to total deposits & 19 & 18 & 17 & 20 & 20 \\
\hline Available reserves to total deposits & 18 & 19 & 20 & 10 & 12 \\
\hline Liquid assets to total assets & 14 & 14 & 13 & 15 & 14 \\
\hline \multicolumn{6}{|l|}{ Profitability Ratios } \\
\hline Net income to average total assets (return on assets) & 4 & 3 & 3 & 6 & 3 \\
\hline Net income to average total equity (return on equity) & 29 & 20 & 20 & 52 & 26 \\
\hline Total expenses to total income & 60 & 64 & 68 & 71 & 74 \\
\hline
\end{tabular}

Source: Central Bank of Swaziland.

${ }^{1}$ Excluding the Swaziland Development and Savings Bank, which is owned by the government and offers both development finance and commercial banking services since its recapitalization and relaunch by the government in 2001. 
Table 40. Swaziland: Summary of the Tax System as of November 1, 2007

(All amounts in emalangeni)

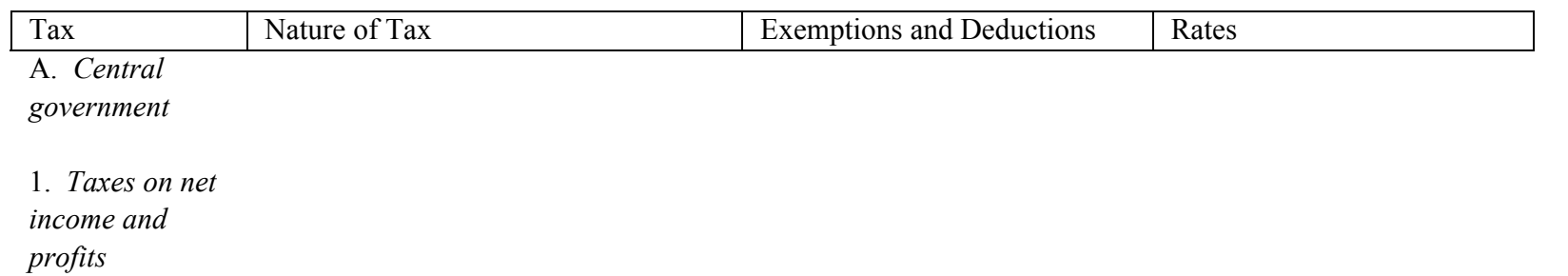

\subsection{Taxes on}

companies

1.11 Company income tax (normal tax). Income Tax Order, 1975, as amended.
Annual income tax is levied on taxable income derived from sources in Swaziland, or deemed to be in Swaziland, by all companies, foreign or domestic, public or private. Agricultural cooperatives, insurance societies, and public utility companies are also considered companies for taxation purposes. Taxable income is defined as gross income (excluding capital receipts, and foreign and exempt income) less allowable deductions (including loss offsets) incurred in the process of production in Swaziland. The assessment year ends June 30 and tax (less provisional tax payments detailed below) is payable annually. Company tax legislation is integrated with personal income tax legislation. Consequently, where exemptions, deductions, and allowances normally appropriate for persons are appropriate for a particular company, these may be claimed (see 1.21 below). For farming companies, net change in livestock and produce held is deemed income (except for companies that opted otherwise under previous tax laws) and will be valued at purchase price or current market prices, whichever is lower.

Provisional tax: a system of provisional taxation is in operation in respect of all companies, directors of private companies, and any person whose income, other than remuneration under the PAYE (payas-you-earn) scheme, exceeds E 1,000 per annum. Provisional taxpayers pay provisional tax on account of their
Exemptions include, inter alia, dividend receipts of companies, receipts and accruals (including those from investments) of life insurance companies, pension benefits or provident funds. Also excluded are the noninvestment profits of societies and associations that are derived solely through transactions with individual members.

Where the Minister of Finance is satisfied that a new business is beneficial to the development of the economy, he may, with prior approval of cabinet, declare that business a development enterprise, and he may issue a "development approval order" in respect of (a) Companies: 30 percent of taxable income.

(b) Companies granted development approval order: 10 percent of taxable income. 


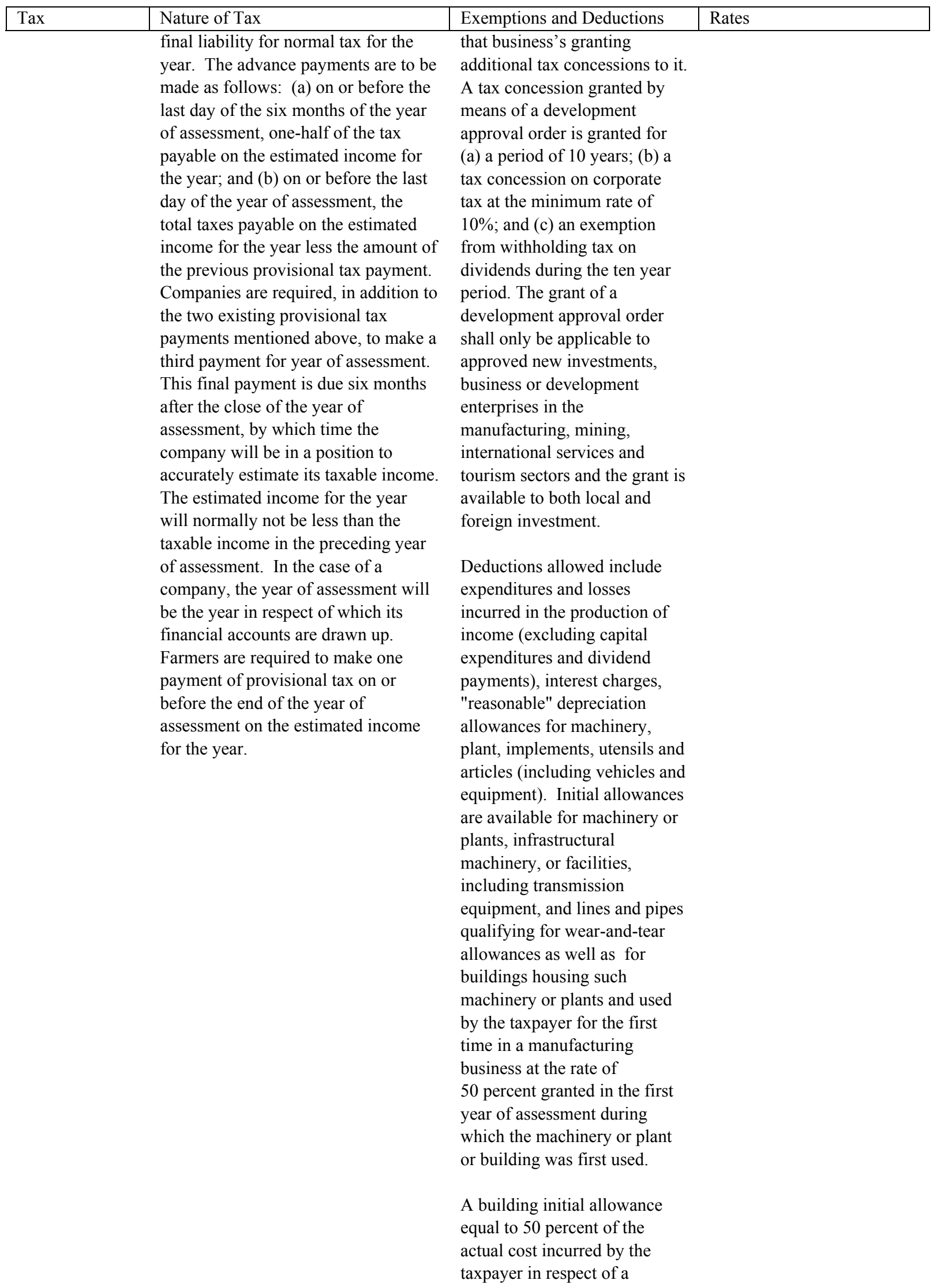




\begin{tabular}{|c|c|c|c|}
\hline Tax & Nature of Tax & Exemptions and Deductions & Rates \\
\hline & & $\begin{array}{l}\text { building and improvements if } \\
\text { such a building is used by the } \\
\text { taxpayer for the purpose of } \\
\text { housing machinery or plant } \\
\text { used directly in the process of } \\
\text { manufacture, and an amount } \\
\text { equal to } 4 \text { percent of the cost to } \\
\text { the taxpayer of any industrial } \\
\text { buildings used in production, } \\
\text { along with actual expenditures } \\
\text { on repairs and maintenance. }\end{array}$ & \\
\hline & & $\begin{array}{l}\text { An allowance in respect of } \\
\text { machinery, implements, } \\
\text { utensils and articles used by } \\
\text { the taxpayer for the purposes } \\
\text { of his trade which have been } \\
\text { scrapped by such taxpayer } \\
\text { during the year of assessment. } \\
\text { An allowance equal to } 20 \\
\text { percent for the first year and } \\
\text { thereafter for the next } \\
\text { succeeding eight years an } \\
\text { allowance of } 10 \text { percent in } \\
\text { respect of expenditure incurred } \\
\text { in connection with the erection } \\
\text { of any dwelling occupied } \\
\text { exclusively by employees } \\
\text { employed by a taxpayer for the } \\
\text { purpose of his own business in } \\
\text { a process of manufacture. }\end{array}$ & \\
\hline & & $\begin{array}{l}\text { The total contribution by a } \\
\text { taxpayer to retirement annuity } \\
\text { funds is limited to the greatest } \\
\text { of (a) } 15 \text { percent of taxable } \\
\text { income accruing to the tax- } \\
\text { payer in respect of trade } \\
\text { carried on by him, provided } \\
\text { such amount shall not exceed } \\
\text { E } 12,000 \text { per annum; or (b) } \\
\text { E } 7,500 \text { less contributions } \\
\text { made by the taxpayer to a } \\
\text { pension fund; or (c) E } 6,000 \text {. }\end{array}$ & \\
\hline & & $\begin{array}{l}\text { Contributions to pension } \\
\text { schemes are limited to } \\
20 \text { percent of employee } \\
\text { remuneration and annuities } \\
\text { (less employees' contribution) } \\
\text { up to E } 6,000 \text { per employee. } \\
\text { Any amount not exceeding } \\
\text { E12,000 paid by way of } \\
\text { annuity during the year of } \\
\text { assessment by any taxpayer (a) }\end{array}$ & \\
\hline
\end{tabular}




\begin{tabular}{|c|c|c|c|}
\hline Tax & Nature of Tax & Exemptions and Deductions & Rates \\
\hline & & $\begin{array}{l}\text { to a former employee who has } \\
\text { retired from the taxpayer's } \\
\text { employ on grounds of old age, } \\
\text { ill-health or infirmity; or (b) to } \\
\text { any person who is dependent } \\
\text { for his maintenance upon a } \\
\text { former employee or where } \\
\text { such former employee is } \\
\text { deceased, was so dependent } \\
\text { immediately prior to his death. }\end{array}$ & \\
\hline & & $\begin{array}{l}\text { An allowance in respect of any } \\
\text { premium or consideration in } \\
\text { the nature of a premium paid } \\
\text { by any taxpayer for the right of } \\
\text { use or occupation of land or } \\
\text { buildings, or for the right of } \\
\text { use of any plant or machinery, } \\
\text { or of any patent, design, trade } \\
\text { mark or copyright or any other } \\
\text { property of a similar nature, if } \\
\text { the property is used or } \\
\text { occupied for the production of } \\
\text { income or income is derived } \\
\text { there from. An allowance for } \\
\text { expenditure incurred by a } \\
\text { taxpayer in pursuance of an } \\
\text { obligation to effect } \\
\text { improvements on land or to } \\
\text { buildings under an agreement } \\
\text { whereby the right of use or } \\
\text { occupation of the land or } \\
\text { buildings is granted by any } \\
\text { other person, if such land or } \\
\text { buildings are used or occupied } \\
\text { for the production of income. }\end{array}$ & \\
\hline & & $\begin{array}{l}\text { The amount of any debt due to } \\
\text { a taxpayer to the extent to } \\
\text { which they are proved to be } \\
\text { bad. An allowance in respect } \\
\text { of debts due to the taxpayer as } \\
\text { the Commissioner considers to } \\
\text { be doubtful. Any interest } \\
\text { payable on loans made to the } \\
\text { taxpayer if the loan was } \\
\text { employed in production of } \\
\text { income or for the purposes of } \\
\text { the trade of the taxpayer. }\end{array}$ & \\
\hline & & $\begin{array}{l}\text { Any contribution, donation, } \\
\text { grant or gift not exceeding } 5 \\
\text { percent of taxable income } \\
\text { made to an amateur sporting } \\
\text { association, charity or }\end{array}$ & \\
\hline
\end{tabular}




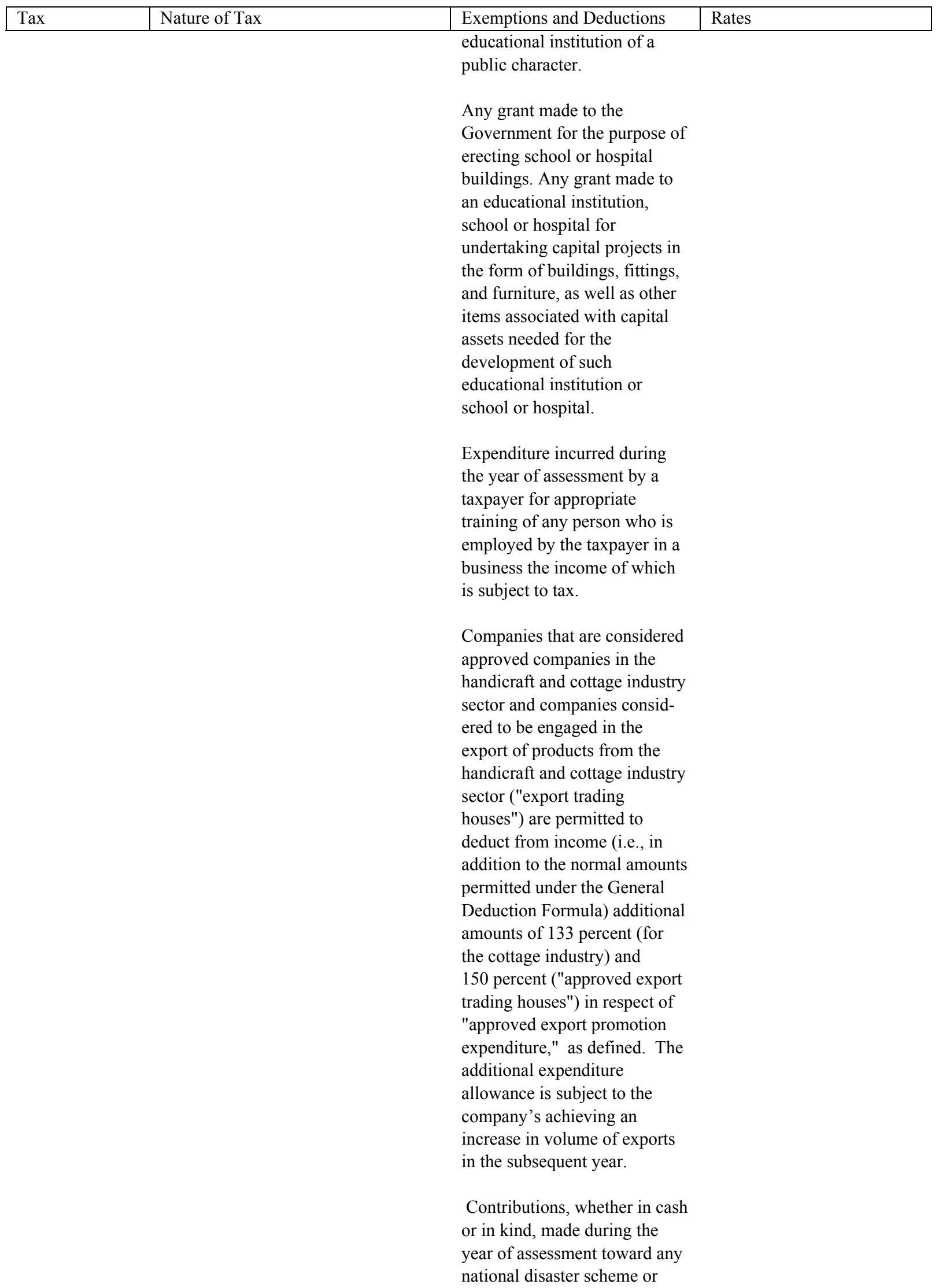




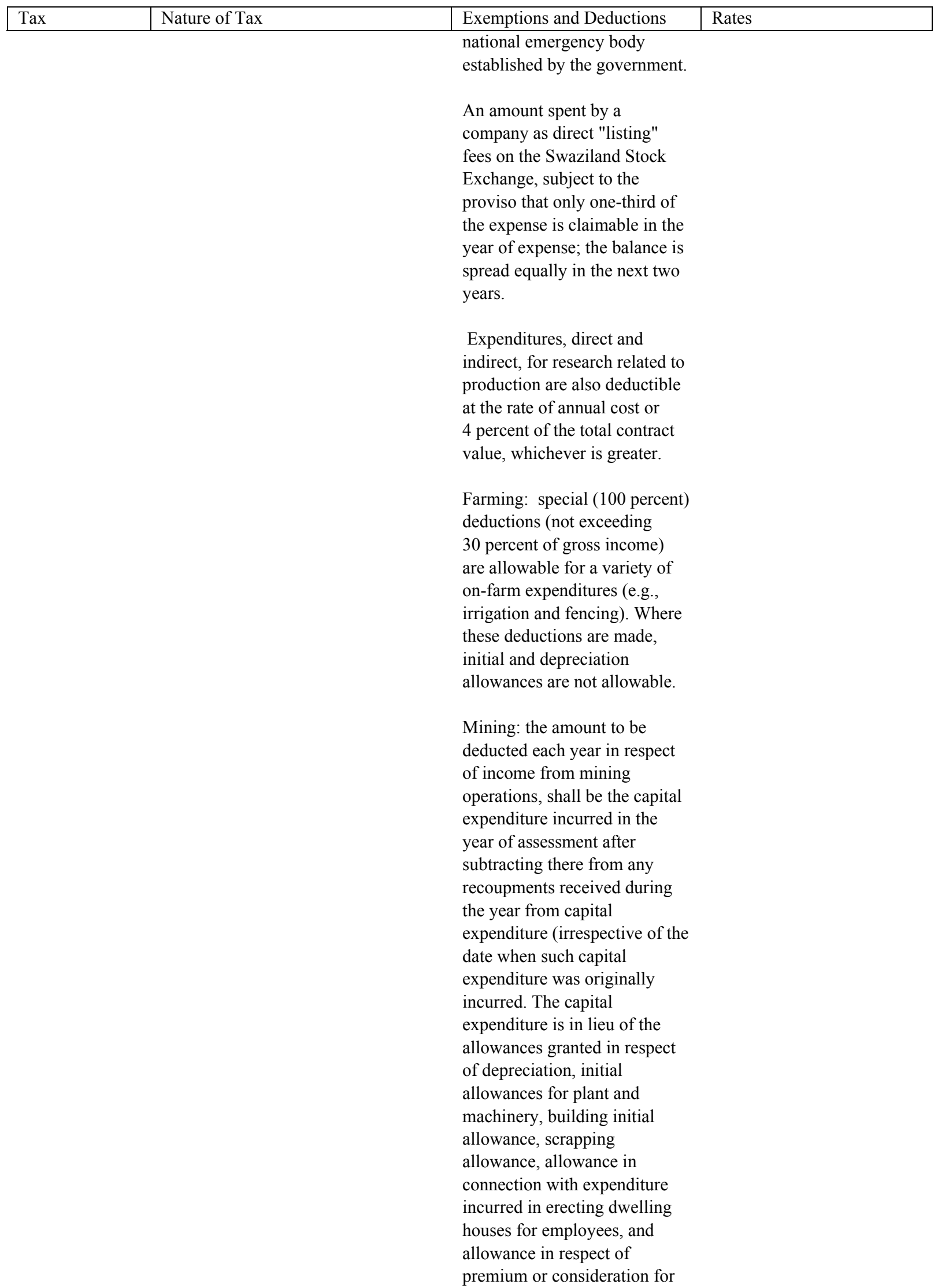




\begin{tabular}{|c|c|c|c|}
\hline Tax & Nature of Tax & Exemptions and Deductions & Rates \\
\hline & & $\begin{array}{l}\text { the right of use or occupation } \\
\text { of land or buildings, or for the } \\
\text { right of use of any plant or } \\
\text { machinery, or of any patent, } \\
\text { design, trade mark or copyright } \\
\text { or any other property of a } \\
\text { similar nature. }\end{array}$ & \\
\hline & & $\begin{array}{l}\text { Capital expenditure is defined } \\
\text { to mean expenditure on: (a) } \\
\text { shaft sinking, building, works } \\
\text { or equipment including any } \\
\text { renewals or replacements of } \\
\text { equipment; (b) development, } \\
\text { general administration and } \\
\text { management (including any } \\
\text { interest payable on loans } \\
\text { utilized for mining purposes) } \\
\text { prior to the commencement of } \\
\text { production or during any } \\
\text { period of nonproduction but } \\
\text { excluding the cost of acquiring } \\
\text { mineral rights; (c) } \\
\text { "expenditure" means net } \\
\text { expenditure after taking into } \\
\text { account any rebates, } \\
\text { recoupments or returns } \\
\text { expenditure; (d) "expenditure } \\
\text { of shaft sinking" includes the } \\
\text { expenditure on sumps, pump } \\
\text { chambers, stations and bins, } \\
\text { accessory to a shaft. }\end{array}$ & \\
\hline
\end{tabular}

1.12 Casino tax. Casino Tax Act, 1963, (Act No. 56, 1963, as amended).
With effect from July 1, 1985, it is composed of an annual license fee and of a levy based on a percentage of the gross gaming room takings of the licensee less any amount paid out as winnings to casino patrons and is payable on an annual basis. A licensee is liable to normal tax. (a) The annual license fee is E 2,000.

(b) A levy payable on the gross gaming room takings of the licensee less any amount paid out as winnings to casino patrons, as follows:

- In respect of the first year of operation of the casino, no levy shall be paid.

- In respect of the second, third, fourth, fifth, and sixth years of operation of the casino, a levy of 2.0 percent shall be paid.

- In respect of the 


\begin{tabular}{|c|c|c|c|}
\hline Tax & Nature of Tax & Exemptions and Deductions & Rates \\
\hline & & & $\begin{array}{l}\text { seventh year and } \\
\text { subsequent years of } \\
\text { operation, a levy of } \\
4.5 \text { percent shall be } \\
\text { paid. }\end{array}$ \\
\hline
\end{tabular}

1.21 Individual income tax (normal tax). Income Tax Order, 1975, as amended.
This is payable, subject to the deductions and exemptions noted, on income received by or accruing to all persons from sources within Swaziland or deemed to be within Swaziland. Tax is payable on assessed "taxable income," which is equal to gross income (excluding capital receipts and exempt income) less losses and allowable deductions. Taxable income includes, inter alia, annuities, wages and salaries, rent investment income, and benefits in kind (perquisites). After the calculation of taxable income and, hence, tax payable, certain "tax abatements" may be deducted where applicable. Effective from the 1 July 2007 , the tax payable by an individual is reduced: (a) by way of a rebate, (i) a primary rebate not exceeding $\mathrm{E} 3,000$ in any year of assessment; and (ii) a secondary rebate of E1 200 if the individual is over the age of sixty years on the last day of the year of assessment. The rebates do not apply where the concessionary rates i.e. rates of normal tax for retiring or redundant individuals; (b) by an amount equal to 10 per cent of the amount paid for a mortgage interest during the year of assessment subject to a maximum of E2, 400; (c) Death, accident, sickness, or unemployment insurance and contributions to provident and benefit funds (other than a medical aid fund) are also subject to tax rebate of 10 percent to a maximum of $\mathrm{E} 360$. With effect from July 1, 1991, both men and women are subject to a uniform system of taxation. (See below under "rates.")

Employees are subject to a monthly withholding at source; other taxpayers are assessed annually. Nonresidents are liable for income tax on income earned in Swaziland (including benefits in kind received for services
The primary tax rebate of E3,000 when combined with the lowest marginal rate of 12 per cent an individual has a threshold of E25,000, and the tax payable by an elderly person will be reduced by an amount not exceeding E4,500 in any year of assessment. A person over the age of sixty years is entitled to both the primary rebate of E3 000 plus then secondary rebate of E1,200. When a tax rebate of $\mathrm{E} 4,500$ is combined with the lowest marginal rates, an elderly person would have a threshold of E34,200.

Exemptions include the following: salaries of U.K. and South African civil servants; consular personnel not permanent residents of Swaziland; war pensions and gratuities; the first E 1,000 of interest income received by or accrued to an individual from a deposit in a financial institution; interest received by nonresidents from Swaziland government securities and bonds; and capital sums due from a provident fund or benefit fund (pension one third of the total value of the annuity to which any employee becomes entitled may be commuted for a single payment); capital sums in commutation of a retirement annuity; Severance allowance or notice pay payable under the Employment Act to an employee on the termination of his services is exempt from normal tax. The first $\mathrm{E} 30,000$ received by or accrued to an individual on retrenchment or retirement.

\author{
Taxable income tax rate \\ Marginal (In percent) \\ (in emalangeni)

$\begin{array}{rr}0-33,000 & 12 \\ 33,001-49,500 & 20 \\ 49,501-66,000 & 25 \\ 66,001-82,500 & 30 \\ 82,501 & 33\end{array}$

Trust income

33 percent of taxable income

Rates of normal tax in the case of a retiring or redundant individual

Taxable income tax rate Marginal (In percent) (in emalangeni)

$\begin{array}{cc}0-60000 & 12 \\ 60,001-120,000 & 20 \\ 120,001-180,000 & 25 \\ 180,001-240,000 & 30 \\ 240,001 & 33\end{array}$




\begin{tabular}{|c|c|c|c|}
\hline Tax & Nature of Tax & Exemptions and Deductions & Rates \\
\hline & $\begin{array}{l}\text { rendered); however, dividends and } \\
\text { interest payments are subject to } \\
\text { special taxes (see } 1.31 \text { and 1.32). } \\
\text { Personal income tax legislation is } \\
\text { integrated with company tax } \\
\text { legislation. Consequently, where } \\
\text { exemptions, deductions, and } \\
\text { allowances normally appropriate for } \\
\text { companies are applicable to persons } \\
\text { (e.g., owner-occupied farms), these } \\
\text { may be claimed. For farmers, net } \\
\text { change in produce and livestock held } \\
\text { is deemed income (except for those } \\
\text { farmers who opted otherwise under } \\
\text { previous tax laws) and will be valued } \\
\text { at the lesser of the purchase price or } \\
\text { current market price (if purchased), } \\
\text { and at standard book valuation } \\
\text { otherwise. } \\
\text { A system of provisional tax is in } \\
\text { operation in respect of self-employed } \\
\text { persons and other individuals whose } \\
\text { income, other than remuneration } \\
\text { subject to PAYE, exceeds E } 1,000 \text { per } \\
\text { annum (see } 1.11 \text { above). One of the } \\
\text { important amendments introduced in } \\
\text { the Income Tax (Amendment) Act } \\
\text { No. } 6 \text { of } 1994 \text { was the introduction of } \\
\text { the Final Deduction System (FDS) for } \\
\text { employees, which came into operation } \\
\text { on July } 1,1993 \text {. FDS constitutes a } \\
\text { final liability to tax and is related to a } \\
\text { full year of assessment. All } \\
\text { employees, no matter how much they } \\
\text { earn, are subject to the FDS, provided } \\
\text { they have not derived any other } \\
\text { taxable income during the year of } \\
\text { assessment. Such employees are not } \\
\text { required to furnish an income tax } \\
\text { return if the income consists solely of } \\
\text { FDent income that is subject to }\end{array}$ & $\begin{array}{l}\text { Dividends received by } \\
\text { nonresidents (see } 1.32 \text { below). } \\
\text { Deductions include, in addition } \\
\text { to those for companies ( } 1.11 \\
\text { above) where appropriate, } \\
\text { employee contributions to pen- } \\
\text { sion funds (maximum E6, } 000 \\
\text { where the pension fund is not } \\
\text { established by law). }\end{array}$ & \\
\hline $\begin{array}{l}1.22 \text { Graded } \\
\text { tax. Graded Tax } \\
\text { Act of } 1968 \text {, as } \\
\text { amended. }\end{array}$ & $\begin{array}{l}\text { This tax is payable by all persons } \\
\text { (apart from the exemptions noted) } \\
\text { resident or domiciled in Swaziland, } \\
\text { and is thus akin to a head tax. Tax is } \\
\text { determined on the basis of gross } \\
\text { income and is payable annually for all } \\
\text { except for employees whose } \\
\text { deductions are made monthly at } \\
\text { source. }\end{array}$ & $\begin{array}{l}\text { Exemptions include all persons } \\
\text { under the apparent age of } 18 \text {, } \\
\text { women earning less than E } 15 \\
\text { per month, visitors, students, } \\
\text { and the chronically ill. }\end{array}$ & $\begin{array}{l}\text { Tax due is determined on } \\
\text { the basis of gross income as } \\
\text { shown below: } \\
\text { Gross income } \\
\begin{array}{ll}\text { E } 0 \text { - E } 299 & \text { E } 4.20 \\
\text { E } 300 \text { - E } 449 & \text { E } 6.00 \\
\text { E } 450 \text { - E } 600 & \text { E } 12.00 \\
\text { Over E } 600 & \text { E } 18.00\end{array}\end{array}$ \\
\hline
\end{tabular}




\begin{tabular}{|c|c|c|c|}
\hline Tax & Nature of Tax & Exemptions and Deductions & Rates \\
\hline $\begin{array}{l}\text { 1.31 Tax on } \\
\text { nonresidents' } \\
\text { interest receipts. } \\
\text { Income Tax } \\
\text { Order, 1975, as } \\
\text { amended. }\end{array}$ & $\begin{array}{l}\text { This tax is payable by persons or the } \\
\text { estate of a deceased person not } \\
\text { resident in Swaziland or a company } \\
\text { not registered in Swaziland on } \\
\text { accrued interest where the debtor } \\
\text { (person or company) is domiciled in } \\
\text { Swaziland. The recipient is legally } \\
\text { liable for the payment of this tax } \\
\text { within } 14 \text { days of the accrual of } \\
\text { interest, but it is normally paid by the } \\
\text { debtor and deducted from interest } \\
\text { remitted. }\end{array}$ & $\begin{array}{l}\text { Exemptions: interest on loans } \\
\text { specifically exempt by } \\
\text { government (usually } \\
\text { government and other public } \\
\text { body loans); building society } \\
\text { shares; interest from loans to } \\
\text { agricultural cooperatives and } \\
\text { public utilities established by } \\
\text { parliament; interest received } \\
\text { by church, charitable, or edu- } \\
\text { cational organizations; and } \\
\text { interest amounting to E } 20 \text { or } \\
\text { less in a full tax year. Also, } \\
\text { interest on importers' bills or } \\
\text { notes is exempt where these } \\
\text { have been handled through the } \\
\text { banking system. }\end{array}$ & $\begin{array}{l}\text { Tax is payable at } 10 \text { percent } \\
\text { of the interest accrued. }\end{array}$ \\
\hline
\end{tabular}

1.32 Tax on nonresident shareholders. Income Tax Order, 1975, as amended.

1.33 Tax on branch profits.
This tax is payable by persons or the estate of a deceased person not resident in Swaziland or any company not registered in Swaziland on dividends received from a company domiciled in Swaziland. This tax is payable on both interim and final dividends and is due within 30 days. Legal liability for payment resides with the recipient, but is normally paid by the payer and deducted from remitted dividends.

Tax is payable on the deemed repatriated income of a branch of a nonresident company.

Noxemptions

This tax is payable by every person who makes payment to a nonresident person under an agreement relating to construction operations. The tax is deducted from each payment made to the nonresident. The nonresident is not relieved from any obligations to furnish returns for income tax and any assessment raised on the nonresident
Exemptions include dividends paid by agricultural cooperatives and dividends received by church, charitable, or educational institutions, as well as dividends accruing to a nonresident shareholder, which the government has, in terms of a written undertaking, exempted from tax.

No exemptions

Tax is payable at the rate of $12 \frac{1}{2}$ percent where dividends are payable to a company incorporated (but not a branch of company headquartered in a third country) in Botswana, Lesotho, Namibia, and South Africa.

For all other destinations, tax is payable at the rate of 15 percent.

Tax is payable at the rate of 15 percent.

A rate of $12 \frac{1}{2}$ percent where repatriated profits are payable to a company incorporated (but not a branch of company headquartered in a third country) in Botswana, Lesotho, Mozambique, Namibia, and South Africa.

No exemptions.

Tax is payable at the rate of 15 percent. 


\begin{tabular}{|c|c|c|c|}
\hline Tax & Nature of Tax & Exemptions and Deductions & Rates \\
\hline & $\begin{array}{l}\text { for income tax will be credited with } \\
\text { the nonresident contractors' tax that } \\
\text { has been paid on his behalf. }\end{array}$ & & \\
\hline $\begin{array}{l}1.35 \text { Tax on } \\
\text { nonresident. for } \\
\text { Swaziland } \\
\text { source services } \\
\text { contract. Income } \\
\text { Tax Order, } \\
\text { 1975, as } \\
\text { amended. }\end{array}$ & $\begin{array}{l}\text { Tax is payable by all nonresident } \\
\text { persons on amounts derived by the } \\
\text { nonresident from performance of } \\
\text { services that gives rise to Swaziland } \\
\text { source income. The tax is payable on } \\
\text { gross amount at source by } \\
\text { withholding. The tax is a final tax. }\end{array}$ & No exemptions. & $\begin{array}{l}\text { Tax is payable at the rate of } \\
15 \text { percent. }\end{array}$ \\
\hline $\begin{array}{l}\text { 1.36 Tax on } \\
\text { nonresident } \\
\text { entertainers and } \\
\text { sportsmen. } \\
\text { Income Tax } \\
\text { Order, 1975, as } \\
\text { amended. }\end{array}$ & $\begin{array}{l}\text { This tax is payable by all nonresident } \\
\text { entertainers and sportsmen who } \\
\text { perform in Swaziland. The tax is } \\
\text { payable on remuneration or gross } \\
\text { receipts of any theatrical, musical, or } \\
\text { sports performance where these } \\
\text { receipts are received directly by the } \\
\text { performers concerned. Legal liability } \\
\text { for payment resides with the } \\
\text { recipients. However, the payer is } \\
\text { legally required to withhold the tax } \\
\text { due from any remuneration payable. }\end{array}$ & There are no exemptions & $\begin{array}{l}\text { Tax is payable at the rate of } \\
15 \text { percent. }\end{array}$ \\
\hline $\begin{array}{l}1.37 \\
\text { Nonresident Tax } \\
\text { on Royalties \& } \\
\text { Management } \\
\text { Charge Income } \\
\text { Tax Order, } \\
\text { 1975, as } \\
\text { amended. }\end{array}$ & $\begin{array}{l}\text { This tax is payable by nonresident } \\
\text { persons on gross amount of any } \\
\text { royalty and management charge } \\
\text { derived from a source in Swaziland. } \\
\text { The tax is withheld at source and it is } \\
\text { a final tax. }\end{array}$ & There are no exemptions. & $\begin{array}{l}\text { Tax is payable at the rate of } \\
15 \text { percent. }\end{array}$ \\
\hline $\begin{array}{l}1.38 \text { Tax on } \\
\text { interest paid to } \\
\text { residents. } \\
\text { Income Tax } \\
\text { Order, 1975, as } \\
\text { amended. }\end{array}$ & $\begin{array}{l}\text { This tax is payable by residents on the } \\
\text { gross amount of interest derived from } \\
\text { every financial institution. The tax is } \\
\text { withheld at source. It is a final tax. }\end{array}$ & There are no exemptions. & $\begin{array}{l}\text { Tax is payable at the rate of } \\
10 \text { percent. }\end{array}$ \\
\hline $\begin{array}{l}1.39 \\
\text { Withholding tax } \\
\text { on dividends } \\
\text { paid to resident } \\
\text { persons. }\end{array}$ & $\begin{array}{l}\text { Tax is payable by a person (other than } \\
\text { a company) resident or carrying on } \\
\text { business in Swaziland. }\end{array}$ & There are no exemptions. & $\begin{array}{l}\text { Tax is payable at the rate of } \\
10 \text { percent. }\end{array}$ \\
\hline $\begin{array}{l}1.40 \text { Tax } \\
\text { clearance } \\
\text { certificates. }\end{array}$ & $\begin{array}{l}\text { A system of tax clearance is in } \\
\text { operation. In terms of a gazette } \\
\text { regulation published recently, tax } \\
\text { clearance is presently needed for the } \\
\text { issue, renewal, or transfer of any } \\
\text { license, other than renewal of motor } \\
\text { vehicle licenses, or similar document } \\
\text { relating to any trade, business, }\end{array}$ & & \\
\hline
\end{tabular}




\begin{tabular}{|c|c|c|c|}
\hline Tax & Nature of Tax & Exemptions and Deductions & Rates \\
\hline & $\begin{array}{l}\text { profession, or vocation; the transfer of } \\
\text { immovable property or any } \\
\text { endorsement to any title deed having } \\
\text { the effect of transferring property; the } \\
\text { registration or deregistration of a } \\
\text { company; first registration of motor } \\
\text { vehicles in Swaziland; and the } \\
\text { tendering for the provision of goods } \\
\text { or services to the government or a } \\
\text { parastatal body, in excess of E } 5,000 \text {. }\end{array}$ & & \\
\hline $\begin{array}{l}\text { 2. Social } \\
\text { security } \\
\text { contributions }\end{array}$ & None. & & \\
\hline
\end{tabular}

